\title{
European Union Competition Policy versus Industrial Competitiveness
}

Stringent Regulation and its External Implications

\section{Hikaru Yoshizawa}

\section{Globalisation, Europe, Multilateralism}

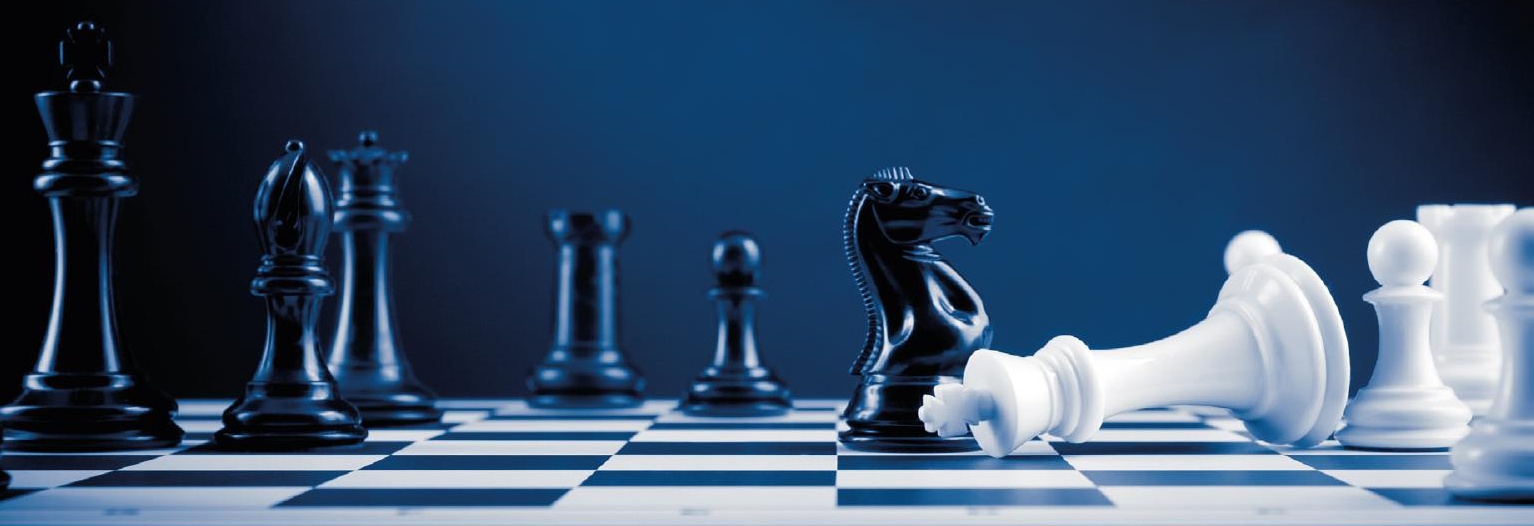


"Yoshizawa provides a much needed and thorough analysis of the European Union's use of competition policy in the global political economy. His timely insights reveal the crucial internal and external dimensions of this policy and how they contribute to the EU's increasingly important approach to the competition-competitiveness dilemma."

Chad Damro, University of Edinburgh, UK

"EU competition policy experts as well as academics will be keen to read this book. It shall interest experts and academics from all over the world."

Janine Goetschy, French National Centre for Scientific Research (CNRS), France 


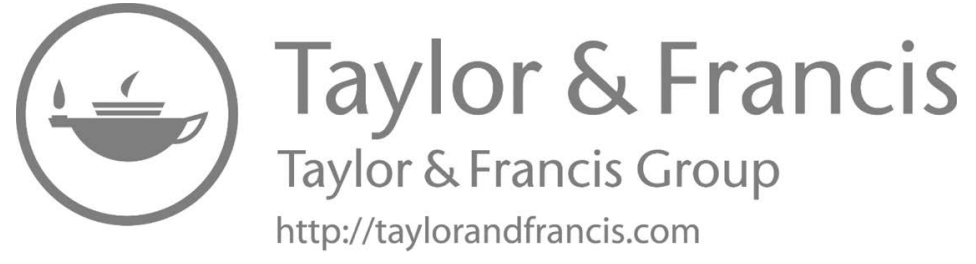




\section{EUROPEAN UNION COMPETITION POLICY VERSUS INDUSTRIAL COMPETITIVENESS}

The book examines whether EU competition policy is applied fairly and consistently to EU and non-EU firms despite persistent political pressure from member states for a relaxation of the rules and deals with the dilemma of regional organisations in the global political economy.

Focussing on the EU's desire to achieve balance between the promotion of market competition and the enhancement of international competitiveness, the book explores the validity of its attempts successfully to ensure a 'stringent competition policy' which is nationality-blind and comparatively strict. Finally, it shows that the competition-competitiveness dilemma remains unresolved because the EU's capability to set global regulatory standards is constrained by competition and the need to engage in multilateral forums, such as the WTO and the International Competition Network.

This book will be of key interest to scholars and students of European Union studies, EU competition law and policy, EU external action and more broadly to global governance, international political economy and international relations.

Hikaru Yoshizawa is Associate Professor in the Faculty of Law at Kansai University, Japan. 


\title{
Globalisation, Europe, Multilateralism Series
}

With the institutional support of the Institut d'études européennes-Université libre de Bruxelles

The series offers an interdisciplinary platform for original peer-reviewed publications on the institutions, norms and practices associated with Globalisation, Multilateralism and the European Union. Each published volume delves into a given dynamic shaping either the global-regional nexus or the role of the EU therein. It offers original insights into: globalisation and its associated governance challenges; the changing forms of multilateral cooperation and the role of transnational networks; the impact of new global powers and the corollary multipolar order; the lessons born from comparative regionalism and interregional partnerships; as well as the distinctive instruments the EU mobilises in its foreign policies and external relations.

Series Editors: Mario TELÒ, Université Libre de Bruxelles, Belgium, and LUISS-Guido Carli, Rome, Italy. Ramona COMAN, Université libre de Bruxelles, Belgium.

\section{International Editorial Board}

Amitav ACHARYA, American University, Washington Leonardo MORLINO, LUISS-Guido Carli, Rome

Shaun BRESLIN, University of Warwick

Tamio NAKAMURA, Waseda University, Tokyo

Marise CREMONA, EUI, Florence

Yaqing QIN, CFAU, Beijing

Louise FAWCETT, University of Oxford

Ummu SALMA BAVA, JNU, New Dehli

Andrew GAMBLE, University of Cambridge

Vivien SCHMIDT, Boston University
Peter J. KATZENSTEIN, Cornell University

Leonard SEABROOKE, Copenhagen Business School

Robert O. KEOHANE, Princeton University

Karen E. SMITH, LSE, London

Christian LEQUESNE, IEP-Paris

Anne WEYEMBERGH, Université libre de Bruxelles

Nicolas LEVRAT, Université de Genève

Michael ZÜRN, WZB, Berlin

Frank MATTHEIS, Université libre de Bruxelles

Series Manager: Frederik PONJAERT, Université Libre de Bruxelles, Belgium.

\section{Regionalism and Multilateralism}

Politics, Economics, Culture

Edited by Thomas Meyer, José Luís de Sales Marques and Mario Telò

\section{Theorising the Crises of the European Union}

Edited by Nathalie Brack and Seda Gürkan

\section{The Unintended Consequences of Interregionalism}

Effects on Regional Actors, Societies and Structures

Edited by Elisa Lopez Lucia and Frank Mattheis

\section{Towards a New Multilateralism}

Cultural Divergence and Political Convergence?

Edited by Thomas Meyer, José Luís de Sales Marques, and Mario Telò

\author{
Global Networks and European Actors \\ Navigating and Managing Complexity \\ Edited by George Christou and Jacob Hasselbalch
}

\section{European Union Competition Policy versus Industrial Competitiveness}

Stringent Regulation and its External Implications

Hikaru Yoshizawa

For more information about this series please visit: https://www.routledge.com/GlobalisationEurope-Multilateralism-series/book-series/ASHSER1392 


\section{EUROPEAN UNION COMPETITION POLICY VERSUS INDUSTRIAL COMPETITIVENESS}

Stringent Regulation and its External Implications

Hikaru Yoshizawa 
First published 2022

by Routledge

2 Park Square, Milton Park, Abingdon, Oxon OX14 4RN

and by Routledge

605 Third Avenue, New York, NY 10158

Routledge is an imprint of the Taylor \& Francis Group, an informa business

(C) 2022 Hikaru Yoshizawa

The right of Hikaru Yoshizawa to be identified as author of this work has been asserted by him in accordance with sections 77 and 78 of the Copyright, Designs and Patents Act 1988.

All rights reserved. No part of this book may be reprinted or reproduced or utilised in any form or by any electronic, mechanical, or other means, now known or hereafter invented, including photocopying and recording, or in any information storage or retrieval system, without permission in writing from the publishers.

Trademark notice: Product or corporate names may be trademarks or registered trademarks, and are used only for identification and explanation without intent to infringe.

British Library Cataloguing-in-Publication Data

A catalogue record for this book is available from the British Library

Library of Congress Cataloging-in-Publication Data

Names: Yoshizawa, Hikaru, author.

Title: European Union competition policy versus industrial competitiveness : stringent regulation and its external implications / Hikaru Yoshizawa.

Description: Abingdon, Oxon ; New York, NY : Routledge, 2022. | Series: Globalisation, europe, multilateralism series | Includes bibliographical references and index.

Identifiers: LCCN 2021021898 (print) | LCCN 2021021899 (ebook) | ISBN 9780367757670 (hardback) | ISBN 9780367757595 (paperback) | ISBN 9781003163909 (ebook)

Subjects: LCSH: Competition--European Economic Community countries. | European Economic Community countries--Economic policy. | Restraint of trade--European Economic Community countries.

Classification: LCC HF1532.5 .Y68 2022 (print) | LCC HF1532.5 (ebook) |

DDC 382/.3094--dc23

LC record available at https://lccn.loc.gov/2021021898

LC ebook record available at https://lccn.loc.gov/2021021899

ISBN: 978-0-367-75767-0 (hbk)

ISBN: 978-0-367-75759-5 (pbk)

ISBN: 978-1-003-16390-9 (ebk)

DOI: $10.4324 / 9781003163909$

Typeset in Bembo

by KnowledgeWorks Global Ltd. 


\section{CONTENTS}

List of illustrations

viii

Acknowledgements

List of acronyms

1 The EU competition policy dilemma 1

2 The institutional basis of strict and non-discriminatory regulation

3 Tension between stringent supranational regulations and national neo-mercantilism

4 The issue of discrimination against non-EU firms

5 Systemic constraints on the EU's role as a global rule-maker

6 The EU: Stuck between competition and competitiveness 


\section{ILLUSTRATIONS}

\section{Boxes}

2.1 Turnover thresholds under the EU's merger regulation 34

3.1 The EU's exclusive competence in large cross-border mergers 64

\section{Figure}

2.1 EU cartel fines, 1990-2019

\section{Tables}

1.1 A comparison of stringent and strategic competition policies 11

2.1 Former and current European Competition Commissioners 24

2.2 The European Commission's key coercive measures in its competition policy

3.1 The European Commission's state aid decisions concerning tax rulings as of 31 March $2021 \quad 70$

4.1 The EU's 10 highest cartel fines by firm as of March $2021 \quad 78$

$\begin{array}{lll}4.2 & \text { Fines imposed in the vitamins case (2001) } & 79\end{array}$

4.3 Fines imposed in the TV and computer monitor tubes case (2012)

4.4 The European Commission's fines for abusive dominance, 1999-2020

4.5 Mergers disapproved by the European Commission, 1990-2020

5.1 Main differences between the WTO and the ICN 


\section{ACKNOWLEDGEMENTS}

This book is an updated and fully revised version of my $\mathrm{PhD}$ dissertation submitted to the Université Libre de Bruxelles (ULB) and the University of Geneva in 2016. I studied at these universities between October 2011 and March 2016 within the framework of the GEM (Globalisation, Europe, and Multilateralism) PhD School, which was funded by the European Commission's Erasmus Mundus Joint Doctorate Programme. After graduation, I continued my research on this topic while working at Japanese universities-Waseda (2014-18), Doshisha (2018-20), and Kansai (2020-present). I acknowledge research grants provided by these universities, the European Commission, and the Japan Society for the Promotion of Science (JSPS): Core-to-Core Programme (A. Advanced Research Networks).

I would like to express my sincere gratitude to my supervisors (Janine Goetschy and René Schwok) and thesis examiners (Amandine Crespy, Chad Damro, and Sandra Lavenex) for their invaluable comments on my dissertation. I am also grateful to the editor and manager of the Routledge GEM book series, Mario Telò and Frederik Ponjaert, and all GEM friends and colleagues. My research has hugely benefited from comments I received at various conferences and meetings in the last ten years in Belgium, Canada, China, Japan, the Netherlands, and Switzerland. I am particularly grateful to Basje Bender, Yuko Suda, Yoichiro Usui, and Angela Wigger, who kindly took the role of my discussants in workshops. I am also thankful to constructive comments and encouragement from two anonymous reviewers selected by Routledge, Gustavo Müller, Shunsuke Sato, Sarah Goler, Coraline Goron, Pola Cebulak, Anna Chung, Raffaele Marchetti, Yane Svetiev, Hassan Qaqaya, Duncan Wigan, Hidetoshi Nakamura, Paul Bacon, Koji Fukuda, Yoshikatsu Washie, Toru Harada, Akira Ichikawa, Takemasa Sekine, Yukari Akeda, Stephen Day, Yorizumi Watanabe, my former colleagues at Waseda University and Doshisha University, and my current colleagues at Kansai University. Last but not least, I would like to thank my family for always supporting me. 


\section{LIST OF ACRONYMS}

$\begin{array}{ll}\text { CNE } & \text { Comisión Nacional de Energía (Spanish National Energy } \\ \text { DG } & \text { Commission) } \\ \text { EC } & \text { European Commission's Directorate-General } \\ \text { ECIS } & \text { European Communities } \\ \text { ECN } & \text { European Committee for Interoperable Systems } \\ \text { ECSC } & \text { European Competition Network } \\ \text { EEC } & \text { European Coal and Steel Community } \\ \text { EU } & \text { European Economic Community } \\ \text { FTA } & \text { European Union } \\ \text { GATS } & \text { Free Trade Agreement } \\ \text { GATT } & \text { General Agreement on Trade in Services } \\ \text { GE } & \text { General Agreement on Tariffs and Trade } \\ \text { GECAS } & \text { GE Capital Aviation Services } \\ \text { ICN } & \text { International Competition Network } \\ \text { ICPAC } & \text { International Competition Policy Advisory Committee } \\ \text { ITO } & \text { International Trade Organization } \\ \text { JBCE } & \text { Japan Business Council in Europe } \\ \text { JETRO } & \text { Japan External Trade Organization } \\ \text { JFTC } & \text { Japan Fair Trade Commission } \\ \text { METI } & \text { Japanese Ministry of Economy, Trade and Industry } \\ \text { MITI } & \text { Japanese Ministry of Trade and Industry } \\ \text { OECD } & \text { Organisation for Economic Cooperation and Development } \\ \text { OS } & \text { Operating system } \\ \end{array}$


PC Personal computer

RVI Renault Vehicule Industriels

TFEU Treaty on the Functioning of the European Union

UNCTAD United Nations Conference on Trade and Development

WTO World Trade Organization 


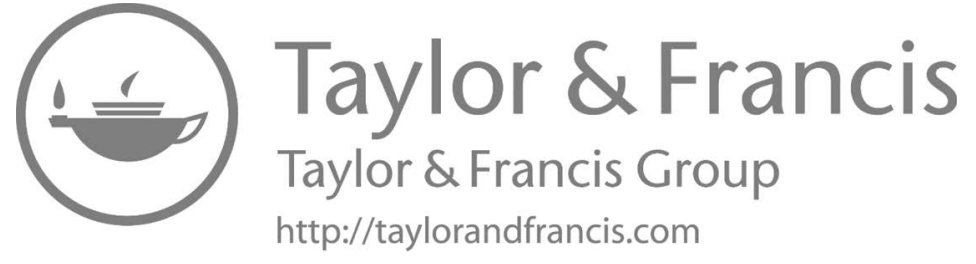




\section{THE EU COMPETITION POLICY DILEMMA}

In the study of European Union (EU) competition policy, there has been a growing interest in a potential tension between two key policy goals (Cini and McGowan 2009: 223-225). On the one hand, the EU enforces its competition law to promote market competition within the European single market. In other words, the first goal is to create a level-playing field in which firms operate freely and compete across the borders between EU member states. On the other hand, the EU aims to ensure that market competition promoted by the law enhances the international competitiveness of firms based in EU member states (hereinafter 'EU firms') in comparison with non-EU firms. In this context, competition in the European single market is considered a springboard that encourages innovation and prepares EU firms to compete in the global market. The European Commission, which plays a central role in this policy domain, has stated numerous times that these goals-competition and competitiveness-can be achieved simultaneously. For example, in its 2013 annual report on competition policy, the European Commission (2014: 2) claimed that '[c]ompetition policy fosters competitiveness in the global context. Healthy competition in the Single Market prepares European companies to do business on global markets and succeed'. However, one should not assume that more competition always leads to stronger competitiveness. The international competitiveness of EU firms would be undermined when the level of European competition regulation is higher than that of its major trading partners (Blauberger and Krämer 2013: 173-174; Dewatripont and Legros 2009: 89). If that is the case, the EU must make a difficult choice between promoting competition for regional economic integration and enhancing the competitiveness of EU firms in relation to their rivals in third countries. In a nutshell, the EU is currently facing what I term a competition-competitiveness dilemma. ${ }^{1}$ 
The main purpose of this book is to examine how exactly the EU deals with this dilemma faced by regional organisations in the global political economy. Specifically, this book addresses three questions that are closely related to each other: (1) Does EU competition policy seek to create or strengthen dominant EU firms at the expense of promoting competition? (2) Does this policy discriminate against non-EU firms for industrial policy purposes? (3) How effective is the EU's attempt to alleviate the dilemma by creating international rules congruent with its own law? The first question is mainly concerned with the internal dimension of this policy, whereas the second one draws attention to its external implications. The third question focuses on the EU's external relations, especially at the multilateral level. The present research is based on the premise that these three aspects are interlinked and should therefore be studied together. The organisation of this book reflects this idea; each of these three aspects is studied in Chapters 3, 4, and 5, respectively.

Drawing on the literature on regulatory states, the book explores a proposal that the EU's supranational institutional setting ensures a 'stringent competition policy' that is nationality-blind and comparatively strict. To test this proposition, the enforcement record of the EU in the areas of cartels, abuse of dominance, mergers, and state aid will be examined based on quantitative data and high-profile cases from the 1990s to 2010s that involved both EU and non-EU firms. The book will also draw on the literature on the EU's policy export, and assess the EU's past and present engagement in rule-making and policy convergence in multilateral forums, such as the World Trade Organization (WTO) and International Competition Network (ICN).

Empirical findings will demonstrate that the EU has been enforcing its competition law quite stringently regardless of the nationality of firms involved in individual cases. Furthermore, EU competition policy has been largely resilient to the global financial crisis of 2007-2008, although the full impact of the current coronavirus pandemic remains to be seen. This stringent approach of the European Commission, which is almost exclusively based on the competition criteria, is contested at times by member state governments that aim to foster 'national champions' (i.e. leading firms based in their territories). Instead of discriminating against non-EU firms, the EU attempts to address the competitioncompetitiveness dilemma by externally promoting competition law and policy. However, the finding will show that the dilemma remains unresolved because the EU's capability to set global regulatory standards is rather limited because of systemic constraints such as competition with the United States, a growing trend of voluntary competition cooperation and policy convergence based on soft law, and the WTO negotiation deadlock on the creation of trade-related competition rules. Overall, the book seeks to contribute to the literature by analysing the external implications of the EU's stringent competition policy in the wider context of the global political economy.

In this book, 'competition policy' refers to a prohibitive public policy that regulates anticompetitive economic activities primarily based on legal measures 
rather than administrative ones. This policy is in sharp contrast with 'industrial policy', which typically involves a relatively large amount of public expenditure and the extensive use of non-binding measures such as administrative guidance. Competition policies usually cover various areas of regulation such as cartels, abuse of a dominant position, and mergers, whereas state aid control may also be the competence of supranational competition authorities such as those of the EU. It should be noted that, reflecting the standpoint of this research, competition policies are defined here in terms of regulatory areas and policy instruments rather than policy goals. Goals of this policy cannot be defined in advance because they vary considerably across time and space. They are largely determined by a specific political process in which various governmental and non-governmental actors interact with each other and advocate their interests and values. In short, the question is 'What is the primary goal of EU competition policy?', and this research will empirically examine it instead of predefining it.

The remainder of this chapter is organised as follows. Section 1 will briefly introduce the content of EU competition policy. Subsequently, it will explain two major criticisms of this policy and the European Commission's response to them to place this research in the context of current political debates. Section 2 will provide a literature review and explain how this book differs from previous studies. Section 3 will develop a theoretical framework, and Section 4 will present the organisation of this book.

\subsection{Political debates about European competition regulation}

While EU competition law covers a wide range of issues, it mainly prohibits four categories of economic activities. ${ }^{2}$ The first category is restrictive practices, which include anticompetitive agreements between firms. ${ }^{3}$ Typical examples of these agreements are hardcore cartels such as price fixing. The second category is the abuse of dominant positions by firms, for example, the imposition of unfair trade conditions on other firms and the use of measures that exclude rival firms' products from the market. The control of these abusive practices is commonly called antitrust policy. The third one is 'concentrations', including mergers and acquisitions, which would substantially reduce competition in a certain market. In the EU, the regulation of these activities is called merger control. The last type of potentially illegal conduct is public aid granted by member state governments to certain firms, industries, and regions. Typical examples of illegal state aid are market-distorting subsidies, unlimited public guarantees, and public loans below market rates.

If there were no public regulation of these anticompetitive practices, the removal of traditional trade barriers such as tariffs and quotas would have been largely ineffective. This is because, for example, the creation of a free trade area may encourage cross-border mergers and foster international monopolies that can make excessive profits from abusing their dominant market positions. This kind of behind-the-border private distortion of market competition could be 
more harmful than traditional at-the-border public barriers to international trade, especially for consumers, and small and medium-sized enterprises. Trade liberalisation among countries may also trigger wasteful subsidy races between them unless effective state aid control exists. For these reasons, articles on competition policy were included in the Treaty of Paris of 1951, which established the European Coal and Steel Community (ECSC), and the Treaty of Rome of 1957, which established the European Economic Community (EEC). Both treaties were singed by the original six countries of these communities (Belgium, France, Italy, Luxembourg, the Netherlands, and West Germany).

In addition to this market integration logic, the European Commission (2012: 9-10) has continuously emphasised the positive contributions of its competition policy to the EU's grand economic strategies, notably the Lisbon Strategy and Europe 2020, which were announced in 2000 and 2010, respectively (European Commission 2010; European Council 2000). According to this view, EU competition policy fosters market competition, boosts innovation, and prepares EU firms for competition on the global stage. The European Commission also insists that its competition policy is compatible with modern industrial policies, such as that of the EU, that encourage innovation instead of directly subsidising selected firms in key sectors. ${ }^{4}$ This point was made, for example, by former European Competition Commissioner Neelie Kroes (2008) and former Director-General for Competition Alexander Italianer (2010) in their public speeches.

However, this official position of the EU has been contested at times. Some people believe that this policy is too strict, obstructs the rise of large EU firms, and undermines their international competitiveness. According to this view, market concentration and business cooperation are generally beneficial and should not be restricted too much. Those who support this argument call for a more flexible EU competition regulation and the greater discretion of member states in developing national industrial policies. Former French President Nicolas Sarkozy was one of the main advocates of this opinion. At the European Council meeting in Brussels in June 2007, he proposed limiting the EU's competition policy competence, arguing that the policy was ideological and dogmatic, and over-constrained national industrial policies (Gow 2007; Lianos 2012: 255-258). Specifically, he suggested removing the goal of free and undistorted competition in the single market, which was originally codified in Article 3(f) of the Treaty of Rome and repeated in subsequent treaties including the Constitutional Treaty of 2004. Consequently, the goal of market competition was deleted from the main text of the Lisbon Treaty of 2007 and moved to Protocol No. 27. So far, this treaty revision has had little practical effect on the EU's competition law enforcement, but this episode illustrated fundamental disagreements among the member states about the balance between competition policies and industrial competitiveness.

Political pressure to downgrade EU competition policy increased again during the 2007-2008 global financial crisis and the subsequent Eurozone crisis. A notable example of such attempts is the harsh criticism of the EU by Arnaud 
Montebourg, former French Minister for Industrial Revival between 2012 and 2014. In an interview by a European media network EURACTIV in October 2013, he asserted that EU competition policy was 'stupid and counter-productive' (Robert 2013). His argument was threefold. First, EU competition policy hinders the emergence of European industrial champions that can compete in the global market. Second, since the EU's major trading partners, such as the United States and China, actively subsidise various sectors and individual firms, it is unwise to maintain strict EU competition rules. Third, for these reasons, EU competition policy is outdated and does not fit the contemporary global economy. In the following year, he went as far as making confrontational arguments with the European Competition Commissioner Joaquín Almunia in open letters, particularly criticising the technocratic decision-making process and the strict enforcement of EU state aid and merger rules (Robert 2014).

Furthermore, there has long been a suspicion that the EU's competition authorities target non-EU firms, and that is why former and current European Competition Commissioners have defended their policy numerous times in front of non-EU audiences. For example, soon after the commencement of her term as European Competition Commissioner, Margrethe Vestager made the following statement in her speech at the Peterson Institute for International Economics in Washington D.C. on 16 April 2015. It was her first public speech to an American audience in her capacity as the European Commissioner.

In all our cases, we are indifferent to the nationality of the companies involved. Our responsibility is to make sure that any company with operations in the territory of the EU complies with our Treaty rules.

(Vestager 2015)

It is clear why she mentioned the issue of nationality-based discrimination on this occasion. One day before this speech, the European Commission sent a statement of objections ${ }^{5}$ to Google, a giant American technology company, regarding an alleged favourable treatment of its comparison shopping services (Google Shopping) on the Internet. ${ }^{6}$ On the same day, the European Commission also announced the initiation of a formal investigation into Google's practices regarding the Android mobile operating system. ${ }^{7}$ Considering the salience of these cases, Vestager tried to explain that the EU was impartial and did not target any non-EU country. However, she could not convince everyone. During her term as a member of the European Commission led by Jean-Claude Juncker (20142019), the EU kept taking a tough stance on American firms, such as Google and Apple, in cases related to abuse of dominance and state aid (see Chapters 3 and 4 for more details). This led former US President Donald Trump to comment in June 2019 that 'she hates the United States perhaps worse than any person I have ever met', and that 'Europe treats us worse than China' (Dallison 2019). In the current European Commission led by Ursula von der Leyen, Vestager serves as Executive Vice-President for 'A Europe Fit for the Digital Age', while retaining 
her responsibility for competition policy. She probably has to continue responding to the accusation that the EU targets non-EU firms for industrial purposes.

As these political debates illustrate, the competition and/versus competitiveness issue and the discrimination issue are directly relevant to current policy discussions about the direction of EU competition policy. That is why the research questions raised at the beginning of this chapter deserve serious consideration. While this section focused on political debates relevant to the present research to place it in context, the next section will review the academic literature on this policy and explain how this book differs from other studies.

\subsection{Contributions of this book}

The literature on EU competition policy is multidisciplinary and multidimensional. While this research area was largely dominated by economists and legal scholars in the past, some political scientists have also extensively published on this subject since the 1990s. More recently, a few historians have entered this field, making the body of literature genuinely multidisciplinary. The scope of research has also expanded over time. A vast majority of studies from the 1960s to the 1980s primarily focused on the internal dimension of this policy, but the external dimension and its interaction with the internal dimension have also been studied extensively since the 1990s.

The internal dimension of EU competition policy has often been assessed in the context of European integration studies. For example, there are books written by lawyers and historians on the historical development of this policy (Gerber 1998; Patel and Schweitzer 2013). Political scientists also studied the historical origin, content, and institutional setting of this policy (Cini and McGowan 2009). In addition, using EU competition policy as a case study, some scholars made theoretical contributions to regional integration studies more explicitly. For example, this policy has been researched from the perspective of neo-functionalism (Büthe 2007; McGowan 2007b), Europeanisation (McCann 2010: 45-70), and historical institutionalism (Warlouzet 2016). Overall, the primary focus of these studies is the political, economic, and legal dynamics within Europe.

More recently, the literature on the external dimension of EU competition policy has developed, putting more emphasis on its global regulatory influence and external relations at the bilateral, interregional, and multilateral levels. There have been lively discussions about the controversial issue of extraterritoriality (Jacquemin 1993), often focusing on high-profile cases involving American firms (Damro 2001; Morgan and McGuire 2004). There are also studies on topics such as transatlantic competition relations (Damro 2006), the EU's failed initiative to establish a WTO competition law (Woolcock 2003), and the overall picture of the European Commission's external competition relations (Aydin 2012; Botta 2014; Yoshizawa 2020). The EU's competition-related agreements with other countries have been studied from a legal perspective (Demedts 2018; Papadopoulos 2010). Furthermore, several scholars published seminal books on 
the EU's external competition policy using explicit theoretical frameworks. For example, from a critical political economy perspective, Buch-Hansen and Wigger (2011) exposed the power struggles and competing economic ideologies behind the policy-making process - aspects often overlooked in competition policy studies. Another important contribution is the book of Damro and Guay (2016) that used the two-level games analytical framework to explain how the internal and external policy dimensions interact with each other.

While these studies have certainly made positive contributions to the literature, this book differs significantly in three respects. First, while previous studies such as Damro and Guay (2016) tend to focus on transatlantic relations, especially in terms of case studies, this book analyses high-profile cases involving Japanese and South Korean firms as well as American and European ones. Second, the book directly addresses the issue of nationality-based discrimination, which is an underexplored and yet crucial issue when analysing the external consequences of the EU's competition regulation. Third, it proposes an original concept of 'stringent competition policy' and distinguishes it from 'strategic competition policy'. While the former is characterised by non-discriminatory and comparatively strict law enforcement, the latter refers to a neo-mercantilist style of competition policy that prioritises the promotion of domestic firms' international competitiveness. This heuristic distinction between the two concepts helps to better understand the distinctiveness of EU competition policy. This book also differs from legal studies on the relationship between the EU's competition and industrial policies (Käseberg and Van Laer 2013; Sauter 1997). While their primary concern is the legal compatibility between these policies, this research focuses on policy practices and examines whether EU competition policy is used for industrial policy purposes.

The discrimination issue mentioned above is more important than ever and deserves serious consideration. If EU competition policy were underdeveloped and extremely lenient, the issue would have been negligible. However, this is certainly not the case. As discussed in detail in Chapter 4, EU competition policy's enormous influence on firms is evident in the huge fines imposed on them, especially in the area of cartels and abuse of dominance. In some cases, the fines accounted for billions of Euros, showing the EU's determination to confront giant multinational corporations. Under certain conditions, the EU can also block mergers and acquisitions between firms whose headquarters are outside EU territory. Therefore, from the perspective of non-EU firms, whether the EU is impartial or not is crucial. The empirical analysis in Chapter 4 will build on recent statistical analyses conducted by legal scholars (Bradford, Jackson, and Zytnick 2018) and economists (Cremieux and Snyder 2016), which addressed the discrimination issue in specific areas. While the former focused on the EU's merger policy, the latter shed light on EU and US cartel policies. Chapter 4 will explore this issue further while putting it in the wider context of the competition and/versus competitiveness issue.

Overall, the present research seeks to have implications for EU studies in two ways. First, it highlights the main characteristics of EU competition policy, 
which plays a key role in European economic governance. It will be argued that EU competition authorities take the goal of industrial competitiveness seriously, but it does not take precedence over the goal of creating a level-playing field in the European single market. This finding indicates that the EU, especially the European Commission, sees competition policies through the lens of the single market despite the emphasis on international competitiveness in the EU's various official documents. Second, this research would also be relevant to the study of EU external action because its findings demonstrate the EU's external regulatory influence while identifying major constraints on it. As discussed in detail in the following chapters, the supranational institutional setting, which was primarily established for internal regulations, seems to hinder the EU's external use of its competition rules in a neo-mercantilist way. This inside-out perspective may be useful for analysing other regulatory policies of the EU that were originally designed for internal socioeconomic regulations.

\subsection{Theoretical framework}

From a theoretical point of view, the literature on regulatory states is particularly relevant to this research. Therefore, this section will first explain what a regulatory state is, why it matters to EU politics, and how it can be applied to the study of EU competition policy. Next, to analyse EU external relations, the literature on its policy export will be reviewed. This stock-taking exercise will help to understand the EU's role in global competition governance. Finally, the research design of this book will be explained.

The notion of regulatory state is useful for analysing the development and dynamics of regulatory policies such as the competition policy. While this notion can be applied to other regions too, it is particularly relevant to EU politics because regulatory policies are highly developed in Europe, especially at the supranational level. ${ }^{8}$ A regulatory state is a state that 'attaches relatively more importance to the processes of regulation than to other means of policymaking' (McGowan and Wallace 1996: 563). The main function of regulatory states is to make and enforce rules primarily based on the rule of law and judicial reviews rather than political decisions. In terms of market interventions, regulatory states are not as active as welfare states and developmental states. Regulatory states correct market failures such as the undersupply of public goods, negative externalities (e.g. pollution), and monopolies. The rise of regulatory states does not necessarily mean a decline of the government. On the contrary, as Majone (1994: 77-80) pointed out, the privatisation and market liberalisation trend in Western Europe in the 1980s paradoxically resulted in more regulation by the government because many de-regulated markets were eventually re-regulated in different ways. As economic interventionism gradually declined over time, the statutory control of the market by independent, non-majoritarian agencies became prevalent in Western Europe as well as other regions (OECD 2002: 19-25). 
This literature on regulatory states is useful for the study of EU competition policy in two ways. First, as a starting point for research, it helps to explain why regulatory policies, such as competition policies, are essential in EU politics. According to this body of research, the development of redistributive policies has been constrained by two major factors: the limited competence of the EU in the area of taxation and spending, and its rather small budget. The EU's budget is dominated by a small number of items, such as agricultural and regional policies, and accounts for only around 1 percent of the member states' total gross domestic product. Consequently, the EU's regulatory policies are generally more developed than its redistributive policies (Majone 1996: 63-64). While redistributive policies require direct public expenditure, regulatory policies are much cheaper and more feasible for authorities such as the European Commission because regulated parties rather than regulators bear a large proportion of administrative costs by adjusting their behaviours to rules and paying fines for law infringements.

Second, the literature on regulatory states helps to understand the institutional setting of the EU in regulatory policies such as the competition policy. Three key points are relevant to the present research. (1) In many regulatory policies, independent agencies play a key role because it is widely believed that they are better placed than majoritarian institutions to assure policy efficiency and effectiveness (Coen and Thatcher 2005). Members of the parliament, a typical majoritarian institution, tend to pursue short-term interests because of electoral cycles. Therefore, if majoritarian institutions are responsible for public regulation, they are likely to use it for redistributive purposes (Hix and Høyland 2011: 190-191). For example, a government led by a left-wing political party would redistribute wealth to workers from others. When a conservative party is in power, the policy would swing in the opposite way. In either case, politicians have an incentive to benefit their main supporters at the expense of other constituencies for electoral considerations. Conversely, independent regulatory agencies at arm's length from ministries can generally make decisions from a long-term perspective based on their legal mandate and expertise. (2) In the context of EU politics, the European Commission can be regarded as an independent regulatory agency that is less likely to be captured by special interests than national authorities because of its relative autonomy from electoral considerations and political party influences (Majone 1996: 71). (3) Since independent regulatory agencies are unelected bodies, their legitimacy depends on their impartiality as well as accountability and problem-solving capabilities (Majone 1999: 12). Therefore, it is essential for these technocratic bodies to enforce laws regardless of the origin of regulated parties. In other words, independent regulatory agencies do not have an incentive to favour particular groups because that would severely damage their credibility as independent and impartial regulators.

These insights indicate that the European Commission, a supranational institution that plays a key role in the handling of individual competition cases, can be regarded as an independent regulator which is relatively autonomous from sectoral and national economic interests, and pursues the goal of correcting 
market failures - a key role of regulatory states. Therefore, one may hypothesise the following:

1. Supranationally institutionalised competition policies, such as that of the EU, prioritise the promotion of market competition over the enhancement of local firms' international competitiveness.

Moreover, the European Commission has a long-term interest in nationalityblind regulation because, unlike national competition authorities, it has to regulate a large number of firms from numerous countries while dealing with transnational regulatory issues. Furthermore, the multinational composition of the College of Commissioners and the staff of the European Commission's bureaucratic bodies such as Directorate-Generals (DGs) make it difficult for the European Commission to agree on measures that favour firms from certain countries (Bradford, Jackson, and Zytnick 2018: 170). Therefore, one may hypothesise the following:

2. The supranational institutional setting hinders the EU's discriminatory use of its competition policy against non-EU firms.

That is not to say that non-discriminatory law enforcement is primarily assured for the benefit of non-EU firms. The main beneficiaries of non-discrimination may well be the European ones. Nevertheless, firms from third countries would also benefit from non-discriminatory regulation; otherwise, the credibility of regulators - in this case, the European Commission - would be seriously undermined.

A competition policy with these features can be conceptualised as 'stringent competition policy'. It focuses on the correction of market failures, such as cartels and monopolies, and prioritises the creation and maintenance of a level-playing field in the market. It is also comparatively strict, indifferent to the nationality of firms, and relatively independent from minimalist or maximalist trends in public market regulation, which depends on the prevailing politics and macroeconomic conditions. It should be noted that non-discriminatory regulation is by no means free from values and interests. Business lobbying may well have an impact on competition-related legislation, and in fact, the European Commission often invites stakeholders, including the private sector, to express their views in public consultations on draft legislation. However, if the EU's competition policy is really a stringent one as proposed above, the European Commission would make decisions on individual competition cases regardless of where the firm comes from.

As summarised in Table 1.1, the concept of stringent competition policy proposed here significantly differs from 'strategic competition policy'. A legal scholar, Roth (2006: 39), defines the latter as 'a policy that goes beyond merely shaping a favourable environment for competition by fostering an attractive infrastructure (in all its dimensions) and sustaining innovation and technological innovation, and conceives and uses competition law as an instrument to assist European 
TABLE 1.1 A comparison of stringent and strategic competition policies

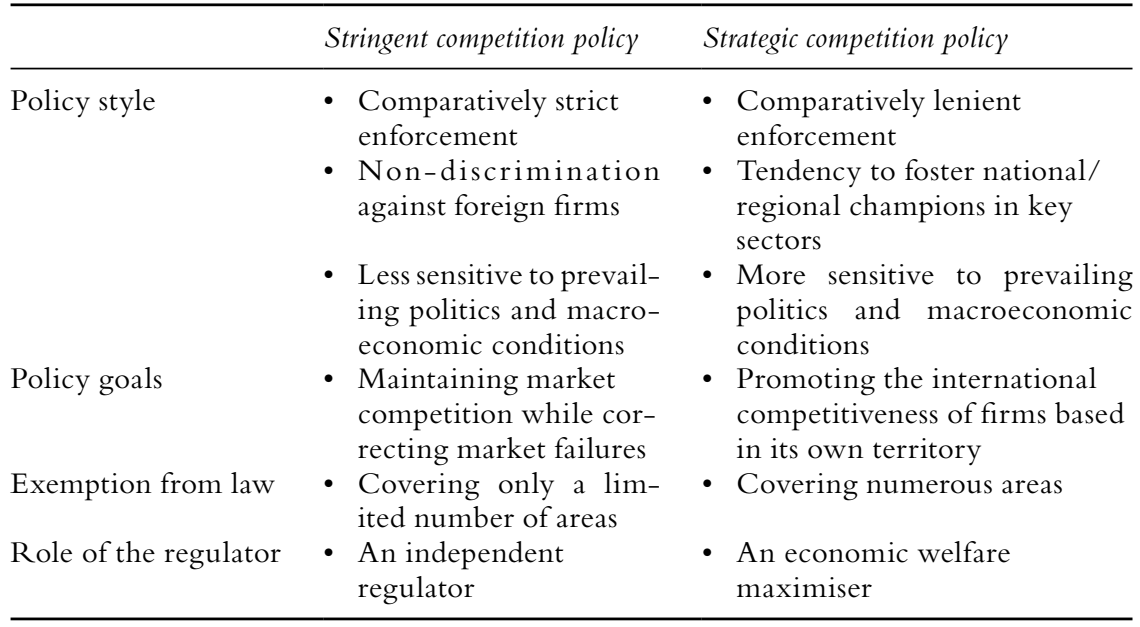

Source: Developed from Jacquemin (1993), Majone (1996), and Roth (2006).

competitors on world markets'. This type of policy prioritises domestic firms' international competitiveness over the goal of promoting competition itself. In other words, the state plays the role of a welfare-maximiser, instrumentally uses competition rules for industrial policy purposes, and aims to foster exportoriented national champions in key sectors (Jacquemin 1993: 94-97). While it is not explicit in the study by Roth, the pursuit of strategic competition policies may involve measures that put foreign firms at a competitive disadvantage. For example, competition authorities may target foreign firms, hinder the acquisition of major local firms by foreign rivals, and exempt numerous categories of economic activities from competition laws to foster domestic industries. The notion of strategic competition policy does not take into consideration the EU's key feature, namely its supranational institutional structure; therefore, the concept of stringent competition policy proposed in this book seems to be more useful for analysing EU competition policy. Nevertheless, empirical research is necessary to ascertain which of these is more useful. It should be noted that these two concepts are not presented here as normative models. They serve as a heuristic device that helps to gain a better understanding of complex EU competition regulations.

With regard to the EU's external competition relations, this book draws on the literature on EU policy export, which provides a useful analytical framework of interactions between the EU and global policy regimes. While the existing literature on the EU and global governance tends to emphasise the impact of EU policies on international regimes, especially in socioeconomic areas, Müller, Kudrna, and Falkner (2014: 1102-1103) argue that 'EU policy export is a demanding phenomenon occurring much less frequently than is commonly assumed'. They define policy export as the 'capacity to actively or passively project its own policy paradigms or norms beyond its borders' (Müller, Kudrna, 
and Falkner 2014: 1106) and suggest that the EU's ability to export its policy to international organisations ('vertical EU policy export') is constrained by four main factors: global setting, global constellation, EU capacity, and EU unity (Müller, Kudrna, and Falkner 2014: 1107). According to them, the key aspects of the 'global setting' are the EU's timing of participation in international negotiations, membership in relevant international organisations, decision-making procedures, and dispute settlement mechanisms. The 'global constellation' concerns the degree to which the EU's preference aligns with those of other key actors. The 'EU capacity' consists of two aspects, namely the legal competence of EU institutions and their capacity based on bargaining power, normative authority, and expertise. This conceptualisation is consistent with other studies that identify market size, regulatory capacity, and internal interest contestation as major factors in the EU's global regulatory influence (Back and Newman 2007; Damro 2012). The 'EU unity' means the willingness of EU institutions and member state governments to take collective external action. When policy export is not politically feasible, the EU may promote second-best rules that are acceptable but not identical to the European ones (policy promotion). Alternatively, the EU may try to hinder the development of international rules that conflict with its preference (policy protection) or adopt established international rules (policy import) (Müller, Kudrna, and Falkner 2014: 1109-1113). Drawing on this analytical framework, Botta (2014) critically examined the EU's attempt to export its competition rules to the global level. ${ }^{10} \mathrm{He}$ explained why the EU's policy export vis-à-vis the WTO failed, while suggesting that the EU's engagement in global competition networks such as the ICN is best understood as a policy protection strategy.

This literature on policy export is useful for the analysis of EU external relations, including external competition relations, because it puts EU-level factors and global factors in a single framework. It helps to give a systematic account of the EU's past and present engagement in global competition-related institutions. Moreover, this analytical framework helps to advance the argument of this book about the EU's stringent competition policy. The literature suggests that the EU may abandon policy export and pursue other strategies when its internal rules are too stringent and demanding for other actors, especially developing countries (Müller, Kudrna, and Falkner 2014: 1109). This point is particularly relevant to the EU's engagement in global competition forums that involve both developed and developing countries. As for the originality of this book, it aims to develop the argument of Botta (2014) in terms of research material and empirical analysis. From a research material viewpoint, this book will conduct a closer examination of the official documents of the WTO and EU. From an analytical viewpoint, it will pay more attention to two aspects of the policy export literature that are not sufficiently studied by Botta. First, regarding the 'global setting', the WTO's decision-making procedures and trade disputes that were concerned with competition issues will be analysed for a better understanding of the EU's failed initiative at the WTO. Second, concerning the 'global constellation', negotiation positions of other major actors, including coalitions of developing countries and 
emerging economies, will be considered. This analysis will complement Botta's study that highlighted competition with the United States as a major factor that constrained the EU's policy export capacity.

Empirical research in the following chapters will be mainly based on three types of data: quantitative data, qualitative case-specific information, and official documents of international organisations about multilateral competition cooperation. The website of DG Competition will be the main source of quantitative data such as the total amount of cartel fines and the top ten cartel fines by case and by company. The case search function of this website will also be utilised to make a list of antitrust and merger cases in which the European Commission made prohibition decisions. ${ }^{11}$ This database covers cartel and antitrust cases from 1999 to the present and merger cases from 1990 to the present. Information about individual competition cases will be mainly collected from the European Commission's press releases and case decisions, EU court judgements, and news articles. In addition, non-EU sources will be used to provide a balanced argument. These include reports of the Japanese Ministry of Economy, Trade and Industry; annual reports of the Japan Business Council in Europe; and speeches of American competition authorities' senior officials. The analysis of multilateral cooperation will draw on various official documents of the EU, WTO, ICN, Organisation for Economic Cooperation and Development (OECD), United Nations Conference on Trade and Development (UNCTAD) as well as secondary sources. These sets of data will be complemented by four elite interviews conducted at DG Competition, the Belgian competition authority, and the Japanese Mission to the EU. These interviews conducted by the author in Brussels are mainly about external competition relations of the EU and its member states, and the Japanese government's perspective on EU competition policy.

Regarding research methods, case studies will be conducted in Chapters 3, 4 , and 5, which correspond to the three research questions, respectively. In Chapters 3 and 4, selected competition cases will be examined to ascertain whether EU competition policy is stringent or not. The method of case studies is used because it is useful for process tracing; it helps to understand the context of competition cases, their key legal and economic issues, and political dynamics behind them. As Chapter 4 discusses the issue of discrimination against non-EU firms, it is important to avoid a case selection bias. Therefore, this chapter will analyse aggregate data as well as high-profile cases. Chapter 5 will analyse multilateral competition cooperation at the WTO and ICN, among others, and two competition-related trade disputes at the WTO. These cases are selected because the WTO was the EU's preference for multilateral rule-making in the 1990s and early 2000s, whereas the ICN represents a recent trend of voluntary cooperation and policy convergence in international competition relations. More details about the case selection criteria will be explained in the following section on the organisation of this book.

Two points should be noted here regarding case selection. First, this research focuses on the EU's action rather than inaction. It could be the case that the 
EU gives a competitive advantage to EU firms by not taking any action against their competition law infringements, but it is very difficult to collect information about potential cases that have been omitted by the competition authority. Therefore, the following analysis only concerns the cases in which the EU officially investigated suspected firms. Second, while there are many older cases that influenced the direction of EU competition law and policy, the vast majority of cases studied in this book are from the period between 1990 and 2020. It begins with 1990 because the DG for Competition ('DG Competition') website's database does not fully cover the period before that. This rather limited time coverage is a limitation of this research, but its result would still be relevant because the external dimension of EU competition policy substantially developed from the 1990s onwards. Having said that, the European Commission's decisions and EU court judgements on several landmark cases in the earlier period will be examined, when necessary, to explain the development of key legal principles in this policy field.

\subsection{Organisation of the book}

The remainder of this book is structured as follows. Chapter 2 will analyse the legal and institutional basis of the EU's internal and external competition regulations. The first section will examine the evolving supranational decision-making process of EU competition policy and argues that the European Commission plays a central role in individual competition cases, even after the major policy reforms in 2004. The second section will explain the content of the four subfields of EU competition policy and the European Commission's major policy instruments in these fields. The third section will show that the legal basis for the EU's extraterritorial application of competition rules has developed over time through case law, whereas the EU also engages in external competition relations at the bilateral, interregional, and multilateral levels. Overall, Chapter 2 shows an institutional basis of the EU's strict and non-discriminatory regulation and lays the foundation for further analyses in subsequent chapters.

Chapter 3 will focus on the internal aspects of EU competition policy and examines whether it has the characteristics of a stringent competition policy, as hypothesised above. Merger and state aid control are the areas in which the EU tends to clash with member state governments over the balance between market competition and industrial competitiveness (Cini and McGowan 2009: 222). Therefore, this chapter focuses on these two areas of EU competition policy. The first section investigates three controversial merger cases that resulted in political conflict between the European Commission and member states: Volvo/Scania (1999-2000), ${ }^{12}$ Siemens/Alstom (2018-2019), ${ }^{13}$ and E.ON/Endesa (2006). ${ }^{14}$ They are selected for case studies for two key reasons. First, they concern politically sensitive areas: motor vehicles, rail transport, and energy sectors. As member states have a tendency to protect their own firms in such sectors, it is worth investigating whether the European Commission pursues stringent merger control in 
these cases despite the risk of political backlash from member states. Second, these cases addressed key issues at the heart of policy debates over the balance between European competition and industrial policies: market definitions, international competitiveness, and the obstruction of acquisitions of domestic firms by foreign capital. Thus, they provide a good test of whether the European Commission prioritises the maintenance of market competition rather than EU firms' international competitiveness. The second part of this chapter will investigate the case of the global financial crisis in 2007-2008 and its aftermath to assess how sensitive the EU has been to mounting political pressure from member state governments to relax European state aid rules. This case is of great importance because state aid is the area in which the EU and member state governments directly confront each other, especially during economic recessions. The European Commission's recent state aid decisions relating to taxation will also be researched because they indicate that EU state aid control, which was relaxed during the global financial crisis, once again became stricter in the mid-2010s. The findings of this chapter will show that the European Commission's merger control has been stringent. State aid control is more sensitive to economic crises, but at the same time its resilience was shown during the global financial crisis.

Chapter 4 will examine the issue of (non-) discrimination against non-EU firms. The analysis will be based on quantitative data and a study of selected controversial cases from the 1990s to the 2010s in the areas of cartels, abuse of dominance, and mergers. Each area will be investigated in two steps: an analysis of aggregate data and case studies. Among the top ten cartels in terms of fine, the Vitamins case ${ }^{15}$ and the TV and computer monitor tubes case ${ }^{16}$ are the ones that involve non-EU firms; therefore, they will be studied to ascertain whether there is any clear evidence of nationality-based discrimination. Reports of the Japanese government and the Japan Business Council in Europe will also be assessed because many non-EU firms involved in EU cartel cases are headquartered in Japan. Regarding the abuse of dominant positions, Microsoft ${ }^{17}$ and Google ${ }^{18}$ will be selected. The Microsoft cases represent a decade-long case in which the firm involved initially refused full compliance with the European Commission's decision. The Google cases are also of great importance primarily because of the highest fines ever on a single company in the history of EU competition policy. In the area of merger control, the General Electric Company (GE)/Honeywell International (Honeywell) case $^{19}$ will be examined. This is a unique case in the sense that it involved non-EU firms exclusively, caused a jurisdictional conflict between the EU and a non-EU country (the United States), and resulted in a prohibition decision by the EU. While the EU's competition policy is often criticised for various governance issues, the result shows no clear evidence of nationality-based discrimination against non-EU firms.

The findings of Chapters 4 and 5 will show that EU competition policy has been stringent. Based on this insight, Chapter 5 will first argue that the EU seeks to promote competition law and policy to address the competition-competitiveness dilemma. Subsequently, the chapter analyses the effectiveness of the EU's external 
rule transfers. The second section provides an in-depth analysis of the EU's failed initiative at the WTO to make an international competition law. This section will also consider implications of two trade disputes at the WTO, namely the Japan-Film case ${ }^{20}$ and Mexico-Telecoms case, ${ }^{21}$ which touched upon the issue of interaction between trade and competition policies. The third part will analyse the broader context of bilateral and multilateral competition cooperation, especially the rise of the ICN, because it typifies the recent trend of soft lawbased governance in this policy area. Findings will show that the main agenda of international competition cooperation has already shifted from rule-making to voluntary policy convergence. This trend makes it difficult for the EU to translate its economic resources and regulatory capacities into a direct influence on international rule-making.

Finally, Chapter 6 will summarise the key empirical findings of the empirical chapters and draw conclusions. Main theoretical and empirical contributions of this chapter will be explained. The chapter also provides further reflections on the implication of the EU's stringent competition policy. Furthermore, the chapter will suggest three potential topics for future research. The first is the long-term impact of the EU's stringent competition policy on non-EU firms, such as Japanese ones. Initial evidence of the internalisation of EU competition norms by the Japanese business community will be presented. The second is the ongoing political debates about the reform of EU competition policy in relation to foreign subsidies and the acquisition of major EU firms by state-owned enterprises. The final topic is the impact of the current coronavirus (COVID-19) pandemic. There is no doubt that the ongoing pandemic is posing one of the biggest challenges to EU competition policy, especially state aid control. This chapter concludes by saying that future research should examine how resilient (or vulnerable) the EU's stringent competition policy is to changes in macroeconomic conditions and prevailing politics.

\section{Notes}

1 While the 'competition-competitiveness dilemma' is the present author's own term, Blauberger and Krämer (2013: 174) proposed a similar idea of 'European competition vs. global competitiveness' in their research on the EU's state aid and public procurement policies. They state that 'European competition and global competitiveness cannot always be reached at the same time, but the two goals have to be balanced against each other'.

2 A policy brief by Marcin Szczepański (2019: 5-16), member of the European Parliamentary Research Service, provides a useful introduction to the four main areas of EU competition policy. This policy also involves other activities such as competition advocacy and consumer relations, but they are not directly relevant to the research questions of this book.

3 To be precise, EU competition law applies to 'undertakings', including firms. The concept of undertaking is defined by the nature of conduct rather than the nature of actors. Therefore, not only firms but also other entities such as trade associations and non-profit organisations may be subject to EU competition law when their activities affect the European single market (Lorenz 2013: 68-70). Nevertheless, the term 
undertaking is avoided in this book because the use of jargons deteriorate readability, and firms are certainly the main target of EU competition policy.

4 See McGowan (2007a) for a further discussion on the relationship between competition and industrial policies at the national and EU levels.

5 A statement of objections is an official document that the European Commission sends to firms under investigation. In the investigation process, the Commission first gathers and assesses information about a competition case. Next, if any potential breach of EU competition law is found, the Commission issues a statement of objections to express its concerns about certain business conduct. Firms that are accused of law infringements have the right to present their views about the statement.

6 Case AT.39740.

7 Case AT.40099.

8 That is not to say that regulation is the only function of the EU. See Caporaso et al. (2015) for discussions on the EU's evolving role in regulatory, stabilisation, and redistributive policies.

9 This concept has been developed based on my earlier research (Yoshizawa 2015).

10 To be precise, Botta contributed to an edited volume and used a similar, slightly earlier version of this framework offered by the editors (Müller and Falkner 2014).

11 The open-access case search section of DG Competition website allows people to search the EU's competition cases (https://ec.europa.eu/competition/elojade/isef/ index.cfm). When we choose a policy area, an advanced search page appears. This advanced search page is useful to look for cases by decision types such as conditional approval and prohibition.

12 Case COMP/M.1672, Volvo/Scania.

13 Case M.8677, Siemens/Alstom.

14 Case COMP/M.4110, E.ON/Endesa.

15 Case COMP/E-1/37.512, Vitamins.

16 Case COMP/39.437, TV and computer monitor tubes.

17 Cases COMP/C-3/37.792, Microsoft, and AT.39530, Microsoft (Tying).

18 Cases AT.39740, Google Search (Shopping); AT.40099, Google Android; and AT.40411, Google Search (AdSense).

19 Case COMP/M.2220, General Electric/Honeywell.

20 Case DS44, Japan-Film (Japan-Measures affecting Consumer Photographic Film and Paper).

21 Case DS204, Mexico-Telecoms (Mexico-Measures Affecting Telecommunications Services).

\section{References}

Aydin, U. (2012). Promoting Competition: European Union and the Global Competition Order. Journal of European Integration, 34(6), pp. 663-681.

Back, D. and Newman, A. L. (2007). The European Regulatory State and Global Public Policy: Micro-Institutions, Macro-Influence. Journal of European Public Policy, 14(6), pp. 827-846.

Blauberger, M. and Krämer, R. U. (2013). European Competition vs. Global Competitiveness: Transferring EU Rules on State Aid and Public Procurement Beyond Europe. Journal of Industry, Competition and Trade, 13(1), pp. 171-186.

Botta, M. (2014). Competition Policy: The EU and Global Networks. In: G. Falkner and P. Müller (eds), EU Policies in a Global Perspective: Shaping or Taking International Regimes? Abingdon: Routledge, pp. 76-92.

Bradford, A., Jackson, R. J. Jr. and Zytnick, J. (2018). Is E.U. Merger Control Used for Protectionism? An Empirical Analysis. Journal of Empirical Legal Studies, 15(1), pp. 165-191. 
Buch-Hansen, H. and Wigger, A. (2011). The Politics of European Competition Regulation: A Critical Political Economy Perspective. Abingdon: Routledge.

Büthe, T. (2007). The Politics of Competition and Institutional Change in the European Union: The First Fifty Years. In: S. Meunier and K. McNamara (eds), Making History: European Integration and Institutional Change at Fifty. Oxford: Oxford University Press, pp. 175-193.

Caporaso, J. M., Kim, M. H., Durrett, W. N. and Wesley, R. B. (2015). Still a Regulatory State? The European Union and the Financial Crisis. Journal of European Public Policy, 22(7), pp. 889-907.

Cini, M. and McGowan, L. (2009). Competition Policy in the European Union, 2nd ed. Basingstoke: Palgrave Macmillan.

Coen, D. and Thatcher, M. (2005). The New Governance of Markets and NonMajoritarian Regulators. Governance, 18(3), pp. 329-346.

Cremieux, P. and Snyder, E. A. (2016). Enforcement of Anticollusion Laws Against Domestic and Foreign Firms. Journal of Law and Economics, 59(4), pp. 775-803.

Dallison, P. (2019). Trump: 'Europe Treats Us Worse than China'. POLITICO Europe. June 26.

Damro, C. (2001). Building an International Identity: the EU and Extraterritorial Competition Policy. Journal of European Public Policy, 8(2), pp. 208-226.

Damro, C. (2006). Cooperating on Competition in Transatlantic Economic Relations: The Politics of Dispute Prevention. Basingstoke: Palgrave Macmillan.

Damro, C. (2012). Market Power Europe. Journal of European Public Policy, 19(5), pp. 682-699.

Damro, C. and Guay, T. R. (2016). European Competition Policy and Globalization. Basingstoke: Palgrave Macmillan.

Demedts, V. (2018). The Future of International Competition Law Enforcement: An Assessment of the EU's Cooperation Efforts. Boston: Brill.

Dewatripont, M. and Legros, P. (2009). EU Competition Policy in a Global World. In: M. Telò (ed), The European Union and Global Governance. Abingdon: Routledge, pp. 87-103.

European Commission (2010). Europe 2020: A Strategy for Smart, Sustainable and Inclusive Growth, $\operatorname{COM}(2010) 2020$ final.

European Commission (2012). Report on Competition Policy 2011, COM(2012)253 final.

European Commission (2014). Report on Competition Policy 2013, COM(2014)249 final.

European Council (2000). Presidency Conclusions: Lisbon European Council, 23-24 March.

Gerber, D. J. (1998). Law and Competition in Twentieth Century Europe: Protecting Prometheus. Oxford: Oxford University Press.

Gow, D. (2007). EU Commissioner Takes on Sarkozy over Competition Rules. The Guardian. June 25.

Hix, S. and Høyland, B. (2011). The Political System of the European Union, 3rd ed. Basingstoke: Palgrave Macmillan.

Italianer, A. (2010). Competition Policy in Support of the EU 2020 Policy Objectives. Speech at Vienna Competition Conference 2010 'Industry vs. Competition?'. Vienna, 9 June [Online]. Available at: https://ec.europa.eu/competition/speeches/text/ sp2010_05_en.pdf [accessed: 31 March 2021].

Jacquemin, A. (1993). The International Dimension of European Competition Policy. Journal of Common Market Studies, 31(1), pp. 91-101. 
Käseberg, T. and Van Laer, A. (2013). Competition Law and Industrial Policy: Conflict, Adaptation, and Complementarity. In: K. K. Patel and H. Schweitzer (eds), The Historical Foundations of EU Competition Law. Oxford: Oxford University Press, pp. 162-190.

Kroes, N. (2008). Competitiveness: The Common Goal of Competition and Industrial Policies. Speech at the Aspen Institute, Paris, 18 April [Online]. Available at: https://ec.europa.eu/commission/presscorner/detail/en/SPEECH_08_207 [accessed: 31 March 2021].

Lianos, I. (2012). Competition Law in the European Union after the Treaty of Lisbon. In: D. Ashiagbor, N. Countouris and I. Lianos (eds), The European Union after the Treaty of Lisbon. Cambridge: Cambridge University Press, pp. 252-283.

Lorenz, M. (2013). An Introduction to EU Competition Law. Cambridge: Cambridge University Press.

Majone, G. (1994). The Rise of the Regulatory State in Europe. West European Politics, 17(3), pp. 77-101.

Majone, G. (1996). The European Commission as Regulator. In: G. Majone (ed), Regulating Europe. London: Routledge, pp. 61-79.

Majone, G. (1999). The Regulatory State and Its Legitimacy Problems. West European Politics, 22(1), pp. 1-24.

McCann, D. (2010). The Political Economy of the European Union. Cambridge: Polity Press.

McGowan, F. and Wallace, H. (1996). Towards a European Regulatory State. Journal of European Public Policy, 3(4), pp. 560-576.

McGowan, L. (2007a). Competition and Industrial Policy. In: C. Hay and A. Menon (eds), European Politics. Oxford: Oxford University Press, pp. 346-362.

McGowan, L. (2007b). Theorising European Integration: Revisiting Neo-Functionalism and Testing Its Suitability for Explaining the Development of EC Competition Policy? European Integration Online Papers, 2, pp. 1-17.

Morgan, E. J. and McGuire, S. (2004). Transatlantic Divergence: GE-Honeywell and the EU's Merger Policy. Journal of European Public Policy, 11(1), pp. 39-56.

Müller, P., Kudrna, Z. and Falkner, G. (2014). EU-Global Interactions: Policy Export, Import, Promotion and Protection. Journal of European Public Policy, 21(8), pp. $1102-1119$.

Müller, P. and Falkner, G. (2014). The EU as a Policy Exporter? The Conceptual Framework. In: G. Falkner and P. Müller (eds), EU Policies in a Global Perspective: Shaping or Taking International Regimes? Abingdon: Routledge, pp. 1-19.

OECD (2002). Regulatory Policies in OECD Countries: from Interventionism to Regulatory Governance. Paris: OECD Publications.

Papadopoulos, A. S. (2010). The International Dimension of EU Competition Law and Policy. Cambridge: Cambridge University Press.

Patel, K. K. and Schweitzer, H. (eds) (2013). The Historical Foundations of EU Competition Law. Oxford: Oxford University Press.

Robert, A. (2013). EU's Competition Rules 'Stupid and Counter-Productive', Montebourg says. EURACTIV. October 24.

Robert, A. (2014). 'War Is Declared' between Montebourg and Almunia. EURACTIV. January 27.

Roth, W. H. (2006). Strategic Competition Policy: A Comment on EU Competition Policy. In: H. Ullrich (ed), The Evolution of European Competition Law: Whose Regulation, Which Competition? Cheltenham: Edward Elgar, pp. 38-52.

Sauter, W. (1997). Competition Law and Industrial Policy in the EU. Oxford: Clarendon Press. 


\section{0}

EU competition policy dilemma

Szczepański, M. (2019). EU Competition Policy: Key to a Fair Single Market. European Parliamentary Research Service, PE 642.209.

Vestager, M. (2015). Competition Policy in the EU: Outlook and Recent Developments in Antitrust. Speech at the Peterson Institute for International Economics, Washington DC, 16 April [Online]. Available at: https://wayback.archive-it. org/12090/20191129202627/https://ec.europa.eu/commission/commissioners/ 2014-2019/vestager/announcements/competition-policy-eu-outlook-and-recentdevelopments-antitrust_en [accessed: 31 March 2021].

Warlouzet, L. (2016). The Centralization of EU Competition Policy: Historical Institutionalist Dynamics from Cartel Monitoring to Merger Control (1956-91). Journal of Common Market Studies, 54(3), pp. 725-741.

Woolcock, S. (2003). The Singapore Issues in Cancún: A Failed Negotiation Ploy or a Litmus Test for Global Governance. Intereconomics, 38(5), pp. 249-255.

Yoshizawa, H. (2015). Strategic or Stringent? Understanding the Nationality Blindness of EU Competition Policy from the Regulatory State Perspective. EU Studies in Japan, 35, pp. 204-225.

Yoshizawa, H. (2020). The EU's External Competition Policy: A Hybrid Approach. In: A. Weyembergh and M. Telò (eds), Supranational Governance at Stake: The EU's External Competences Caught between Complexity and Fragmentation. Abingdon: Routledge, pp. $195-208$. 


\section{2}

\section{THE INSTITUTIONAL BASIS OF STRICT AND NON- DISCRIMINATORY REGULATION}

Chapter 1 proposed that the EU's supranational institutional setting ensures a stringent competition policy that is nationality-blind and comparatively strict. The chapter also proposed that the EU promotes competition law and policy externally to deal with the competition-competitiveness dilemma. These propositions were based on three assumptions: First, EU competition policy is primarily administered by supranational institutions. Second, the EU possesses adequate capacity to regulate anticompetitive business activities within the union. Third, the EU has a clear legal basis for exercising extraterritorial jurisdiction and building external relations with non-EU countries. The goal of this chapter is to prove these assumptions, which are relevant to empirical research in the subsequent chapters of this book. The first section analyses how the decision-making process of EU competition policy has evolved over time. The analysis focuses on the power balance between national governments, intergovernmental institutions, and supranational institutions. The second section explains the four main sub-fields of EU competition policy and shows their similarities and differences in terms of procedures, legal measures, and policy priorities. The third section explores the development of three legal doctrines that underpin the EU's extraterritorial application of its competition law. Furthermore, this section explains a legal basis for the EU's external competition relations.

\subsection{Evolving supranational governance}

Competition policies are highly technical, but at the same time they are also significantly constrained by the political climate and macroeconomic conditions. Therefore, to understand the origin and development of EU competition policy, one should consider the political and economic context of Western Europe before and after the Second World War. A few European countries enacted their 
first competition laws in the 1920s. For example, the Weimer Republic legislated its competition law in 1923 to stimulate market competition and alleviate the hyperinflation that occurred after the First World War (Gerber 2010: 164). However, these nascent competition laws were short-lived. After the breakout of the Great Depression in 1929, numerous European countries tolerated cartels and other restrictive business practices to protect domestic producers. There is widespread belief in Europe that this process of market concentration and cartel formation, which was associated with protectionism, further aggravated the economic recession and confrontations between states. It is also widely believed that market concentration contributed to the maintenance of German and Italian totalitarian regimes based on economic centralisation (Gerber 2010: 166-167). This experience in the interwar period was one of the main reasons for the inclusion of competition provisions in the Treaty of Paris of 1951, which established the ECSC, and the Treaty of Rome of 1957, which established the EEC. ${ }^{1}$ Another key reason was that the original six member states of the EEC did not possess mature competition laws that could deal with anticompetitive business practices across borders (European Commission 1958: 61). Supranational competition rules were adopted to regulate these practices, which would negatively affect trade between member states. In other words, the EEC's competition policy was intended to operate as a functional complement to the common market project (Goyder and Albors-Llorens 2009: 11-12; Jones and Sufrin 2016: 35-36).

Articles 85-94 of the Treaty of Rome laid down the rules on competition, but these rules were vague and left ample room for interpretation. This ambiguity is largely attributable to disagreements between the German and French governments during the treaty negotiation process (Warlouzet 2016: 729-731). In essence, the German government sought to establish the principle of prohibition, according to which market dominance would be inherently illegal. Conversely, the French government preferred the principle of abuse, which would prohibit the abuse of market dominance. The ambiguous provisions of the treaty were a compromise between the two sides. Another shortcoming of these rules was that they did not specify the roles of national and supranational institutions in the enforcement of EEC competition law.

The law became enforceable only after the EEC's Council of Ministers adopted Regulation 17/62 in February 1962. The adoption of this regulation represented an important milestone in EEC competition policy. It was the first law for the implementation of the treaty's Article 85 on restrictive practices and Article 86 on the abuse of dominance (currently Articles 101 and 102 of the Treaty on the Functioning of the European Union [TFEU]). The regulation established a centralised law enforcement system whereby the European Commission enjoyed considerable investigative and decision-making powers. The first European Competition Commissioner, Hans von der Groeben (West Germany), described the sensitive legislative process in his monograph about the formative years of the EEC published in 1985. According to him, France had proposed that member state governments and the European Commission 
would jointly enforce Articles 85 and 86 of the treaty, and that the application of Article 85(3) concerning exemptions from cartel rules would not require prior notifications to the Commission. However, West Germany and the Netherlands had rejected this proposal because it 'would in practice have led to the prohibition principle being replaced by the abuse-prevention principle' (von der Groeben 1985: 109). France ultimately withdrew its proposal and supported the establishment of a supranational decision-making system. While the outcome of the negotiation was determined by various factors, including the positions of member states (especially West Germany), the European Commission, and nonstate actors (Pace and Seidel 2013: 64-77), one of the main reasons for France's concession was that its vital interests had already been secured in parallel negotiations on the common agricultural policy (von der Groeben 1985: 108-110). In retrospect, the adoption of Regulation 17/62 was a 'critical juncture' that had a long-term effect on the decision-making process of the EEC's competition policy (Warlouzet 2016: 733-734). The regulation laid the foundation for a supranational competition policy of the EEC (later European Communities [EC] and EU), primarily administered by the European Commission.

This does not mean that the policy developed rapidly after the adoption of the regulation. The enforcement of supranational competition rules remained relatively weak in the 1960s and the 1970s. From a legal point of view, the Treaty of Rome and Regulation 17/62 did not provide a clear definition of key legal concepts, such as 'abuse' and 'dominance'. Therefore, the supranational competition law developed only incrementally through European Commission decisions, litigation by private actors, and EU court judgements (Büthe 2007). Furthermore, the treaty provided no clear legal basis for supranational merger regulations. From a political point of view, member states did not fully support the strict enforcement of supranational competition rules. In the 1960s and the 1970s, numerous member states extensively used interventionist economic policies, including industrial subsidies, while adopting lenient policies towards various anticompetitive practices such as cartels and mergers. There was a widespread belief in member states that these business practices would positively contribute to industrial development, international competitiveness, and economic growth (Buch-Hansen and Wigger 2011: 57-72). In such a context, '[w]hatever its legal powers, the Commission had to remain sensitive to the balance of political opinion at the national governmental level if it was to avoid a powerful backlash against authority' (McCann 2010: 51). The oil crises of the 1970s further undermined public confidence in stringent competition regulations. Responding to pressure from member states and the private sector, the European Commission exempted some restrictive agreements from EC competition law ('crisis cartels') and remained largely reactive in the policy-making process.

The political climate changed in the late 1980s and the 1990s. EC member states signed the Single European Act in 1986 and set the goal of establishing a European single market by 1992. Regional economic integration was revitalised, and international trade and investment between member states 
increased. Consequently, the EC and its member states attached more importance to the supranational competition policy to ensure that market competition was not distorted by restrictive business practices and state aid. In this sense, efforts to develop supranational competition regulations were assisted by the rise of neoliberalism and the market liberalisation trend from the mid-1980s onward (Buch-Hansen and Wigger 2011: 73-87). The European Commission's 1985 'Completing the Internal Market' white paper stressed the importance of supranational competition regulations for the single market project. The document stated that 'any action taken to ensure the free movement of factors of production must necessarily be accompanied by increased surveillance by the Commission in the field of competition rules to ensure that firms and Member States adhere to these rules' (European Commission 1985: 8). Furthermore, the paper stated that 'a strong and coherent competition policy' was necessary to ensure that 'protectionist state aids or restrictive practices by firms' would not distort competition in the European single market (European Commission 1985: 8). Against this background, the enforcement of supranational competition rules was strengthened under the leadership of high-profile and economically liberal European Competition Commissioners, such as Peter Sutherland and Leon Brittan (McCann 2010: 49-57; Wilks and McGowan 1996: 245-249). Table 2.1 provides a list of former and current European Competition Commissioners.

The EC gained competence to control corporate mergers only in 1989. In the 1970s and the 1980s, the Council of Ministers rejected the European Commission's proposal to introduce supranational merger rules three times, primarily because they were regarded as obstacles to the creation of national champions. However, the Commission persistently waited for a 'window of opportunity' to open, and the Council ultimately agreed on EC merger law to address two major challenges (Majone 1996: 74-75; McGowan and Cini 1999: 179-180). First, in the Continental Can judgement of 1972 and the Philip Morris judgement of 1987, the European Court of Justice ruled that Articles 85 and 86

TABLE 2.1 Former and current European Competition Commissioners

\begin{tabular}{lll}
\hline Name & Country & Period \\
\hline Hans von der Groeben & West Germany & $1958-1967$ \\
Emanuel Sassen & The Netherlands & $1967-1970$ \\
Albert Borschette & Luxembourg & $1970-1976$ \\
Raymond Vouel & Luxembourg & $1976-1981$ \\
Frans Andriessen & The Netherlands & $1981-1985$ \\
Peter Sutherland & Ireland & $1985-1989$ \\
Leon Brittan & The United Kingdom & $1989-1993$ \\
Karel Van Miert & Belgium & $1993-1999$ \\
Mario Monti & Italy & $1999-2004$ \\
Neelie Kroes & The Netherlands & $2004-2010$ \\
Joaquín Almunia & Spain & $2010-2014$ \\
Margrethe Vestager & Denmark & $2014-$ present \\
\hline
\end{tabular}

Source: Developed from annual reports of the European Commission on competition policy. 
of the EC treaty applied to certain cross-border mergers. These judgements increased legal uncertainty. Second, the Single European Act entered into force in 1987 and prompted cross-border mergers. Consequently, the risk of jurisdictional conflicts between member states increased. Numerous multinational corporations and business associations advocated common merger rules to alleviate these problems. In 1989, the Council of Ministers adopted the first EC legislation on merger control, Regulation 4064/89, and significantly broadened the scope of EC competition policy.

Today, EU competition policy exemplifies supranational economic governance. Its decision-making process has two key aspects: legislation and the handling of individual competition cases. Regarding legislation, the EU possesses exclusive competence regarding competition-related legislative actions under Article 3(1) of the TFEU. Therefore, domestic rules adopted by EU member states do not override EU competition law. In the legislative process, both supranational and intergovernmental institutions play significant roles. In the area of competition, EU institutions usually follow the consultation procedure for legislation under Articles 103 and 109 of the TFEU. Under this procedure, the European Commission proposes a piece of legislation (a draft 'regulation' or 'directive') and sends it to the European Parliament and the EU Council. Subsequently, the EU Council adopts, rejects, or amends the proposed legislation by a qualified majority after consulting the European Parliament. When the legislation concerns not only competition policy, but also the approximation of national laws under Article 114 of the TFEU, the EU follows the ordinary legislative procedure. For example, Directive 2014/104 on Antitrust Damages Actions, which entered into force in December 2014, was adopted in accordance with the ordinary legislative procedure. ${ }^{2}$ Under this procedure, the European Parliament and the EU Council adopt, reject, or amend legislation proposed by the European Commission. It should be noted that an intergovernmental institution, the EU Council, plays a key role in both types of legislative procedures.

Conversely, the European Commission and EU courts play a prominent role in the enforcement of EU competition law in individual cases (Cini and McGowan 2009: 41-59; Wilks 2010: 146-150). Within the European Commission, DG Competition is primarily responsible for the enforcement of EU competition law. DG Competition investigates competition cases and prepares draft decisions on such cases. Subsequently, the College of Commissioners, comprising 27 European Commissioners, adopts a final decision on the matter by a simple majority. In reality, decisions are often made by consensus. The Commission's decisions may be appealed to the General Court and Court of Justice of the EU. In the area of restrictive practices, abuse of dominance, and mergers, the Advisory Committee, consisting of the officials of national competition authorities, submits its opinion before the adoption of a final decision. However, this opinion is not legally binding. Amid the intergovernmental negotiations on Regulation 17/62, France proposed to give decision-making powers to the committee, but the regulation conferred only a consultative power on this body 
(Pace and Seidel 2013: 82-84). In these policy areas, neither the EU Council nor the European Parliament has formal powers in case assessment. In the area of state aid, the EU Council has the power to approve the state aid of member state governments under Article 108(2) of the TFEU. However, this procedure is seldom used because it requires unanimity among members.

This supranational decision-making process has become more complex after the 'modernisation reforms' of 2004, which were concerned with the enforcement of Articles 101 and 102 of the TFEU on restrictive practices and the abuse of dominant positions. In the early 2000s, the EU conducted the 'modernisation reform' of its competition policy under the leadership of the European Competition Commissioner, Mario Monti. This was partly a preparation for the EU's eastern enlargement, that would increase the administrative burden of DG Competition, but also a response to mounting pressure on the European Commission to update its procedural and substantive competition rules (Cini and McGowan 2009: 59-61). The reforms aimed for more efficient and effective regulation based on closer cooperation with member state governments. The central pillar of these reforms was Regulation 1/2003, which entered into force on 1 May 2004. ${ }^{3}$ Under Articles 2 and 5 of this regulation, national competition authorities and the courts of EU member states apply Articles 101 and 102 of the TFEU in individual cases in parallel with the European Commission. These national competition authorities would not only deal with individual antitrust cases but also issue block exemptions, which exempt certain categories of economic activities from EU restrictive practice control under Article 101(3) of the treaty.

Consequently, the EU's competition law enforcement system was decentralised to a certain extent. Between 2004 and 2014, over 85\% of decisions that applied Articles 101 and 102 of the TFEU were adopted by national competition authorities (European Commission 2017). However, a careful reading of Regulation $1 / 2003$ reveals that the European Commission retains the power to decide the overall direction of the EU's competition policy (Wilks 2005). Regarding the power balance between the Commission and national competition authorities, a crucial provision is Article 11(6) of the regulation. The article states that the initiation by the Commission of legal proceedings 'shall relieve the competition authorities of the Member States of their competence to apply' Articles 101 and 102 of the TFEU. This means that national competition authorities cannot handle cases that are already under investigation by the European Commission. Competition lawyers Jones and Sufrin (2016: 1019-1020) state that the existence of Article 11(6) is 'a powerful weapon in the hands of the Commission and gives it considerable leverage' over national competition authorities.

The European Competition Network (ECN) was established in 2004 to ensure the coherent enforcement of EU competition law after the modernisation reforms of that year. The ECN consists of DG Competition and national competition authorities. This network of public authorities facilitates case allocation, information transfer, and policy convergence between these entities (Jones and Sufrin 2016: 1014-1019). The ECN is not a mere tool of the European 
Commission to impose its regulatory standards on EU member states; it is a network that promotes the informal sharing of expertise and mutual learning in an experimental way among the European Commission and national competition authorities (Svetiev 2010). On 11 December 2018, the European Parliament and the EU Council adopted Directive 2019/1, concerning the further empowerment of national competition authorities. ${ }^{4}$ This so-called 'ECN plus' directive was adopted to ensure that the competition authorities of EU member states possess adequate enforcement and fining powers and resources necessary to apply Articles 101 and 102 of the TFEU effectively. EU member states were required to adopt domestic rules necessary to comply with Directive 2019/1 by 4 February 2021; the impact of this directive remains to be seen. Nevertheless, since its main objective is to set minimum regulatory standards to improve the enforcement capabilities of national competition authorities, the directive is unlikely to undermine the European Commission's position in EU competition law enforcement.

Overall, the European Commission possesses strong investigative and decision-making powers in competition policy. Neither the EU Council nor the European Parliament plays a significant role in individual competition cases. Furthermore, the Advisory Committee, which consists of representatives of EU member states, only plays a consultative role in individual cases. Modernisation reforms and the ECN plus directive have empowered the competition authorities of EU member states and have led to the establishment of a regulatory network of national and supranational competition authorities. However, the European Commission and EU courts are still the most influential actors in the enforcement of EU competition law. This supranational institutional setting is a distinctive feature of EU competition policy.

\subsection{Four main regulatory areas}

The four main areas of EU competition policy are interlinked and complementary, but they follow different rules, involve different legal measures, and face distinctive challenges. Therefore, it is important to understand the features of each area with regard to its investigation process, regulatory instruments, and policy priorities.

The first policy area is restrictive practices, referring to anticompetitive agreements and concerted practices between undertakings, most notably firms. The main legal basis for this policy is Article 101 of the TFEU enforced by the European Commission and national competition authorities. With regard to policy scope, the article only applies to anticompetitive business conduct that affects trade between EU member states. To be precise, Article 101(1) prohibits 'all agreements between undertakings, decisions by associations of undertakings and concerted practices which may affect trade between Member States and which have as their object or effect the prevention, restriction or distortion of competition within the internal market'. A typical example of restrictive practices is 'price-fixing' agreements by which firms commit to the maintenance of 
high prices. Another example is 'market-sharing' agreements by which firms promise not to enter each other's geographic markets to restrict competition. In principle, these practices are illegal and invalid. However, they may be permitted under Article 101(3) if they contribute to 'improving the production or distribution of goods or to promoting technical or economic progress, while allowing consumers a fair share of the resulting benefit'. This provision is the legal basis for 'block exemptions' issued by the European Commission and national competition authorities to exempt certain categories of transactions from the EU's restrictive practices control.

Regulation 1/2003 lays down detailed rules on the application of Article 101 of the TFEU (European Commission 2013a). The European Commission opens Article 101 cases based on a complaint, the Commission's own initiative, or an application for the leniency programme. The leniency programme grants firms a full exemption or reduction of fines in exchange for information about their cartels (see details below). Once a case is opened, DG Competition exercises its investigative powers detailed in Regulation 1/2003. Articles 17-21 of the regulation empower DG Competition to inspect firms; the inspection is sometimes conducted without notifying firms ('dawn raids'). DG Competition also has the power to request firms to provide relevant information. Firms will be fined if they fail to submit the requested information within a set time frame. The European Commission has three main options when it finds the infringement of Article 101 TFEU. First, the Commission may prohibit the action under Article 7 of Regulation 1/2003 while imposing fines on the firm. As laid down in Article 23(2) of the regulation, the fine can be up to $10 \%$ of the firm's turnover in the previous business year. Second, the Commission may accept the commitments proposed by the firm to address competition concerns. This kind of decision under Article 9 of Regulation 1/2003 is called a 'commitment decision'. After the Commission makes a decision, the commitment will be legally binding. Third, in the context of cartel cases, the Commission may use a settlement procedure that was introduced in 2018. ${ }^{5}$ This simplified procedure enables the Commission to settle cartel cases faster while granting a $10 \%$ reduction in fines to cartel participants.

The top priority of the EU's restrictive practice control has changed over time. In the EC era, the European Commission initially focused on 'vertical constraints', which refer to competition-restricting agreements between firms at different stages of a supply chain. It is difficult to explain this policy orientation from a purely economic perspective because 'horizontal agreements' between competitors may be as harmful to the economy as vertical agreements. A plausible explanation for this is that the European Commission targeted vertical constraints that geographically fragmented the European common market because market integration was one of the main goals of the EC' competition policy (Gerber 1994: 101-102). A famous case concerning a vertical agreement was Consten-Grundig in the 1960s, which involved a French retailing company, Consten, and a German electronics manufacturer, Grundig. In this case, the European Commission prohibited the agreement by which they decided that 
Consten would be the only dealer of Grundig products in the French market. These firms appealed to the European Court of Justice, but the court upheld the Commission's decision on the grounds that the vertical agreement impeded European economic integration by dividing the market along national borders. ${ }^{6}$ As this case illustrates, the court generally supported the Commission's pursuit of market integration and the maintenance of market competition through competition policy. The Commission tackled vertical restraints in various sectors, in which large manufacturers imposed exclusive conditions on dealers. The primary focus of the Commission's restrictive practice policy gradually shifted from vertical to horizontal agreements, especially cartels. This change reflected a broader gradual shift of EU competition policy in the 1990s from a legalistic approach to a new approach that relies more heavily on economic analyses. As mentioned earlier, the goal of market integration was central to the Commission's initial competition policy, but after the establishment of the single market in 1992, the Commission started to rely more heavily on the discourse that market competition itself is beneficial for consumers (Gerber 1994: 143-147). From the viewpoint of consumer welfare, it makes sense to target cartels because they directly cause harm to consumers by increasing the prices of certain products.

A remarkable trend in EU cartel control is a sharp increase in fines over the last two decades. Figure 2.1 shows an upward trend in the number of detected cartels, the total amount of fines, and the average fine per case between 1990 and 2019. It is noteworthy that the total amount of fines between 2000 and 2004 was nearly 12 times larger than that between 1995 and 1999. Furthermore, the amount more than doubled between 2005 and 2009, and remains very large at present. Similarly, the average fine per case sharply increased in the 2000s, and there was an additional modest increase in the 2010s. These changes show that

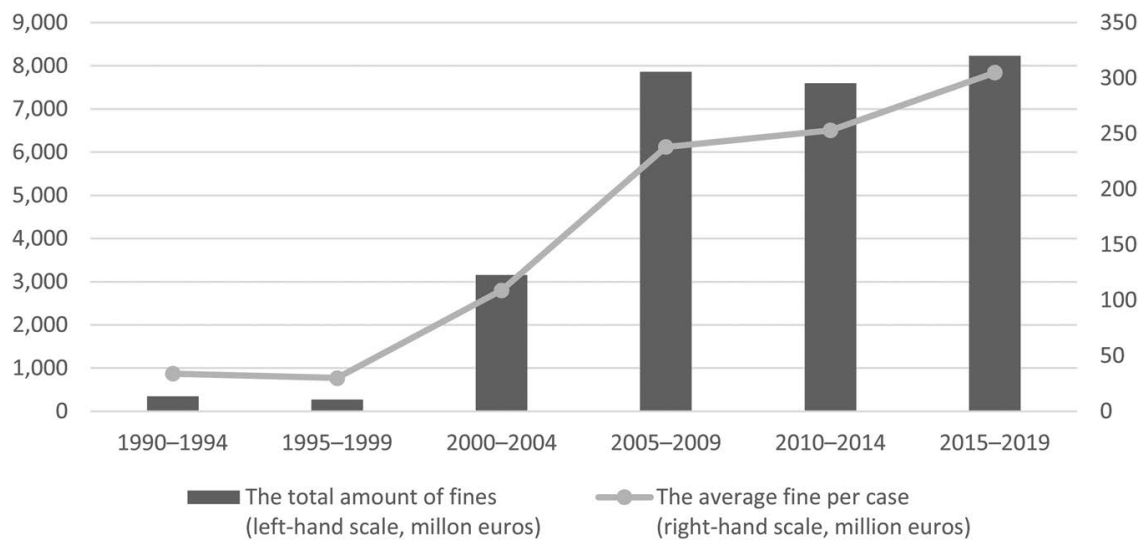

FIGURE 2.1 EU cartel fines, 1990-2019

Source: Adapted from DG Competition's website, '1. Cartel Statistics', pp. 2 and 5: https:// ec.europa.eu/competition/cartels/statistics/statistics.pdf, accessed 31 March 2020.

EU cartel fines increase 
the EU has become more powerful than ever in this policy area. The EU exerts enormous regulatory influence on firms based on coercive measures.

There are four main reasons why the EU has become very active in penalising cartel activities (McGowan 2010: 156-165). First, recent European Competition Commissioners have played a proactive leadership role in strengthening EU cartel control. The European Competition Commissioner between 2004 and 2010, Neelie Kroes, was particularly committed to the fight against cartels. Second, there were several increases in the number of DG Competition personnel. The number reached around 750 by the mid-2000s, and this expansion enabled DG Competition to restructure its organisation while creating a new carteldedicated directorate in 2006. Third, the EU's leniency programme was revised and became more effective. Since this programme worked relatively well in the United States, the EU also introduced it in 1996. It was revised in 2002 and 2006 to clarify the assessment criteria. ${ }^{7}$ According to the current rule, the first 'whistle-blower' will be granted immunity from fines, and the others will be granted a reduction of fines $(30-50 \%$ for the second applicant, $20-30 \%$ for the third applicant, and up to $20 \%$ for other applicants). The programme has significantly increased the EU's cartel detection capability by making it easier for DG Competition to obtain information about cartels from insiders. Finally, the European Commission updated its guidelines on the method of setting fines in 2006 to reinforce its fight against cartels. ${ }^{8}$ The new guidelines allow the European Commission to impose a heavier fine in case of serious infringements of EU law on restrictive practices and abuse of dominance. Specifically, the new guidelines have empowered the Commission to increase the fine against 'repeat offenders' (paragraph 28). There was another important change in the method of setting fines with regard to the duration of infringements (paragraph 24). In the past, the fine was increased by $10 \%$ for each additional year of infringement (e.g. a $50 \%$ increase in the case of a five-year-long cartel). In contrast, under the current system, the fine is multiplied by the number of infringement years (e.g. 500\% of the basic amount in the case of a five-year-long cartel). Some commentators say that the EU's fining policy should be even stricter to enhance cartel deterrence. Nevertheless, fines are clearly the European Commission's main coercive measure for the regulation of cartels and other restrictive practices.

The second policy area, abuse of dominance, concerns the conduct of dominant market players in the EU market. This policy field is also known as monopoly policy. As in the case of restrictive practices, Article 102 of the TFEU only applies to conduct that affects trade between EU member states. Article 102 states that '[a]ny abuse by one or more undertakings of a dominant position within the internal market or in a substantial part of it should be prohibited as incompatible with the internal market in so far as it may affect trade between Member States'. As this indicates, dominant positions are not illegal per se, but their abusive use constitutes the infringement of EU competition law. Article 102 provides a non-exhaustive list of abusive business practices. They include setting prices below costs ('predatory pricing'), requiring resellers to purchase certain products 
only from the dominant supplier ('exclusive purchasing'), and selling products to customers only if they also purchase other products from the dominant company ('tying' and 'bundling').

With regard to the investigation process, restrictive practices and abusive dominance are quite similar because they are based on the same legislation, Regulation 1/2003. Article 102 cases begin either by a complaint or through the opening of an investigation by the European Commission's own initiative. There are three main steps in case assessment (European Commission 2013b). First, the Commission defines the relevant product and geographic markets. Second, the Commission assesses whether the firm under investigation has a dominant position in the relevant market, taking into consideration the firm's market share and other economic factors, such as the existence of rivals and entry barriers. Finally, if the market analysis shows that the firm is in a dominant position, the Commission examines whether it has been abused. The Commission may clear the case, provide conditional approval under Article 9 of the regulation ('commitment decisions'), or prohibit certain business practices under Article 7 ('prohibition decisions'). Prohibition decisions may be associated with the imposition of fines up to $10 \%$ of the firm's annual turnover.

Abusive dominance control developed more slowly than restrictive practice control in the EU and remains highly controversial (Cini and McGowan 2009: 119-123). While the European Commission made important decisions on restrictive practices in the 1960 s, Article 82 of the EC treaty (currently Article 102 of the TFEU) was applied for the first time in $1971 .{ }^{9}$ There are two main reasons for this slow development. First, the treaty article is short and does not provide a clear definition of key concepts, such as market dominance and collective dominance. The concept of market dominance gradually developed through case law, including key judgements in the late 1970s. ${ }^{10}$ The notion of collective dominance, which refers to the collective abuse of dominant positions by two or more firms, developed through case law as late as the 1990 s. ${ }^{11}$ Second, abusive dominance cases tend to be highly complex and require extensive investigations and detailed economic analyses, which often last for many years. The main reason for this complexity is that EU law requires the European Commission to prove not only the existence of dominance, but also its abuse in the relevant market. Furthermore, Article 102 cases frequently involve lengthy lawsuits because dominant market players usually have more financial and human resources and are better prepared to appeal European Commission decisions in EU courts.

Despite these constraints, a relatively small number of European Commission decisions on high-profile cases over the past few decades has had a significant impact on European and global markets, particularly the information and technology sector. As discussed in detail in Chapter 4, the cases often involved American firms, although this does not necessarily mean that the EU discriminates against them. The most famous case is that of Microsoft. In 2004, the European Commission imposed fines of 497 million euros on Microsoft, an American computer software company, for the infringement of Article 102 of the 
TFEU. ${ }^{12}$ This case attracted widespread media coverage, but it merely marked the beginning of a long court battle between the Commission and Microsoft. Due to non-compliance with Commission decisions in this and another one, ${ }^{13}$ Microsoft faced additional fines of 899 million euros and 561 million euros in 2008 and 2013, respectively. An American computer chip manufacturer, Intel, was levied record-breaking fines of 1.06 billion euros in 2009 for the abuse of its dominant position. ${ }^{14}$ The European Commission broke the record again in three cases involving Google, the provider of the world's most popular Internet search engine. Google was levied fines of 2.42, 4.34, and 1.49 billion euros in 2017, 2018, and 2019, respectively. ${ }^{15}$ These cases suggest two recent trends. First, the Commission has become more active in abusive dominance control, even though it may cause resentment among large firms and governments in their countries. Second, the rapid expansion of digital economies around the world has raised the issue of regulating digital platform providers whose conduct has a significant impact on the EU economy. This issue is concerned with all aspects of EU competition policy, but is particularly relevant to the area of abuse of dominance. Today, the regulation of digital platform providers and other information technology firms is a major challenge faced by the EU in the area of abuse of dominance.

The third element of EU competition policy is merger control. It regulates cross-border 'concentrations' such as mergers, acquisitions, and joint ventures that affect competition in the EU market. In many official EU documents, these transactions are collectively called 'mergers' for simplicity. Mergers are typical business strategies and do not necessarily harm the economy. On the contrary, they often improve economic efficiency thanks to economies of scale and bring about innovation due to synergistic effects. Therefore, competition laws, including that of the EU, only prohibit certain types of mergers. Competition laws generally prohibit mergers that are likely to cause negative economic effects by reducing the number of major market players and by significantly impeding competition in certain markets. In this sense, merger control inherently involves the analysis of potential economic effects rather than actual effects. In other words, merger control can be regarded as a kind of pre-emptive monopoly policy. From a competition policy perspective, mergers between competitors ('horizontal mergers') are generally more problematic, but vertical and conglomerate mergers may also create or strengthen market dominance.

While EU merger control has a relatively short history, it has already experienced major reforms since the 2000s. As mentioned in the previous section, the member states used to retain their sovereignty over merger control; the EU gained competence in this area only in 1989, the year in which Regulation 4064/89 was adopted. The introduction of this first merger regulation has been widely regarded as a breakthrough development. It made the European Commission, including DG Competition, a more powerful watchdog equipped with a wider range of policy instruments for market regulation. At the same time, EU merger control often faced severe criticism, especially during the 
term of European Competition Commissioner Mario Monti between 1999 and 2004 (Levy 2005: 104-108). During this period, the European Commission was accused of poor economic and legal analyses in several high-profile merger cases. For example, the GE/Honeywell decision in 2001, which blocked a merger between two American firms, received widespread criticism that the European Commission's analysis relied too much on speculation about future anticompetitive conduct, especially in the case of conglomerate mergers (see Chapter 4). Furthermore, in 2002, the Court of First Instance of the EU overturned three European Commission decisions made between 1999 and 2001. ${ }^{16}$ These three judgements (Airtours, Schneider, and Tetra Laval) were a major blow to the European Commission because EU courts had generally been a key ally in the history of EU competition policy. The criticism of the Commission in these judgements was severe. For example, in the Airtours judgement, the Court of First Instance stated that the Commission's decision was based on insufficient evidence and contained 'errors, omissions and inconsistencies of upmost gravity' (paragraph 404). In response to these severe criticisms, a series of legislative and policy reforms were conducted between 2002 and 2004 (Levy 2005: 111-131). Three of these were particularly significant. First, the European Commission appointed the first Chief Competition Economist in 2003, who was responsible for advising DG Competition and the European Commissioner on competition cases, especially complex ones that require advanced economic analyses. Second, the Commission adopted new guidelines on the assessment of horizontal mergers in 2004 to clarify how exactly DG Competition calculates market shares and concentrations in the review of horizontal mergers. ${ }^{17}$ Third, the EU's new merger legislation, Regulation 139/2004, ${ }^{18}$ entered into force in 2004 to address various procedural and substantive problems, such as the inflexible time frame of merger reviews. These reforms were conducted in the broader context of the European Commission's efforts at that time to apply more advanced economic models to the analysis of competition cases.

Regulation 139/2004 defines the scope and procedures of EU merger control (European Commission 2013c). The scope of EU merger rules is defined in Article 1 of the regulation. It states that the EU exercises jurisdiction over mergers with a 'Community dimension', which is currently called an 'EU dimension'. Mergers are considered to have an EU dimension when they reach certain turnover thresholds (see Box 2.1). Mergers that affect the EU market but do not meet these thresholds are examined by the competition authorities of EU member states. ${ }^{19}$ This case allocation system is based on the 'one-stop shop' principle (Regulation 139/2004, introduction, point 8) and seeks to reduce the burden of merging firms and the risk of jurisdictional conflicts between national and supranational competition authorities. Regarding the investigation process, EU merger control is based on a pre-notification system (Article 4) and a two-phase review process (Articles 6, 7, and 8). The former means that firms must notify all mergers with an EU dimension to the European Commission before implementing them. If merging firms violate this rule, the Commission may impose fines 


\section{BOX 2.1 TURNOVER THRESHOLDS UNDER THE EU'S MERGER REGULATION}

The EU exercises jurisdiction over mergers with a Community dimension, which is currently called an EU dimension. Article 1 of Council Regulation 139/2004 defines mergers with a Community dimension. Article 1(2) sets the turnover thresholds as follows:

2. A concentration has a Community dimension where:

a. the combined aggregate worldwide turnover of all the undertakings concerned is more than EUR 5000 million; and

b. the aggregate community-wide turnover of each of at least two of the undertakings concerned is more than EUR 250 million, unless each of the undertakings concerned achieves more than two-thirds of its aggregate community-wide turnover within one and the same Member State.

Furthermore, Article 1(3) specifies mergers that do not meet these thresholds but are still large enough to have a Community dimension. In this way, Article 1 distinguishes between national and supranational jurisdictions over merger cases. Note that mergers can have a Community dimension, even if the firms are headquartered outside the EU. What matters is their turnover rather than their location.

of up to $10 \%$ of their annual turnover (Article 14). The two-phase review system has two main purposes. First, it helps the Commission clear unproblematic mergers faster in the first phase. Second, it allows the Commission to invest more time and energy in assessing particularly problematic cases in the second phase. All notified mergers undergo a Phase I review. While most cases are usually approved at this stage with or without conditions, mergers that raise serious competition concerns will be subject to a Phase II review. This involves thorough investigations and usually requires more time. After the Phase II review, the Commission decides to (1) clear the merger unconditionally, (2) approve it with conditions, or (3) disapprove it entirely. Since merger plans are time-sensitive, the regulation sets a time frame for merger reviews (Article 10). In principle, the Phase I review must be no longer than 25 working days, and the Phase II review must be no longer than 90 working days. These periods may be extended to a certain extent in case the European Commission and the merging firms negotiate 'remedies' to address competition concerns. Remedies refer to legally binding commitments made by merging firms, such as the divestiture of certain assets.

From a political point of view, the European Commission faces two key challenges in merger control. They will be analysed in Chapters 3 and 4, respectively. The first challenge is mounting political pressure from member states that 
demand more lenient competition regulations. The second challenge is occasional but serious conflicts with other economies, especially the United States, over cross-border mergers.

The fourth component of EU competition policy is state aid control, which is primarily based on Articles 107-109 of the TFEU. In contrast to other areas, state aid rules regulate the actions of member state governments rather than firms. This supranational regulation of public aid to industries is a distinctive feature of EU competition policy. In the past, three DGs of the European Commission were responsible for state aid control. The agricultural and fisheries sectors were handled by the DG for Agriculture and Rural Development and the DG for Maritime Affairs and Fisheries, respectively. However, the von der Leyen Commission transferred these competences to DG Competition on 1 January 2020 (EURACTIV 2019). Therefore, DG Competition is currently responsible for the whole body of EU state aid law.

As in many other areas, treaty provisions on state aid establish a principle and exceptions. Regarding the principle, Article 107(1) prohibits illegal aid in a very broad sense. It states the following:

Save as otherwise provided in the Treaties, any aid granted by a Member State or through State resources in any form whatsoever which distorts or threatens to distort competition by favouring certain undertakings or the production of certain goods shall, in so far as it affects trade between Member States, be incompatible with the internal market.

With regard to exceptions to this principle, Article 107(2) provides a list of aid that 'shall' be compatible with the EU's internal market, whereas Article 107(3) lists types of aid that 'may' be compatible with the internal market. For example, public aid to 'remedy a serious disturbance in the economy of a Member State' is permitted under Article 107(3)(b). This exemption from EU state aid law has proven crucial in the wake of the global financial crisis and the outbreak of coronavirus disease. Apart from measures in such exceptional circumstances, the European Commission adopts 'block exemption' regulations to exempt certain categories of state aid from EU law. For example, Regulation 651/2014 generally exempts regional aid, aid to small and medium-sized enterprises, aid for research and development, and aid for environmental protection, among others. ${ }^{20}$

Since Article 107 is vague and leaves ample room for interpretation, the definition of illegal state aid has been clarified over time by EU court judgements and the European Commission's soft law, such as notices. ${ }^{21}$ Member states have often attempted to circumvent EU state aid law by granting 'creative' forms of state aid. In response, the Commission has incrementally clarified the meaning of illegal state aid while defining 'good' state aid based on its policy priorities (Blauberger 2009). Consequently, state aid under EU law has become an encompassing concept that includes not only subsidies, but also various forms of public financial support to industries such as tax breaks, preferential purchasing, loans, and loan guarantees. 
The treaty provisions and Regulation 2015/158922 lay down detailed state aid procedures (European Commission 2013d). The procedures have two features, as in the case of merger control. First, unlike the WTO's subsidy control based on ex post reviews, the EU conducts ex ante reviews of state aid plans under Article 108(3) of the TFEU. In principle, member states must receive approval of state aid measures from the European Commission before implementing them. Second, the Commission uses a two-phase review system to regulate state aid. According to this system, the Commission conducts a Phase I investigation into a measure notified by a member state. Next, the Commission approves the case with or without conditions or initiates a thorough Phase II investigation into the case within two months. There is no time limit for the Phase II investigation. The Commission's final decision will be approval, conditional approval, or disapproval ('a negative decision') of the notified measure. In addition, if illegal aid has already been paid out, the Commission has the power to require the member state concerned to recover that aid with interest from the beneficiary ('the recovery of aid'). There is a limitation period of ten years for recovery, but this power of the Commission is considerable.

As the European Commission (2011: 7) admits, EU state aid control has 'developed gradually from scratch' over time. It was not until 1973 that the European Court of Justice confirmed the European Commission's power to require member states to recover illegal state aid. ${ }^{23}$ Generally speaking, EU state aid control remained less active until the 1980s and became more active only in the 1990s. There are four main reasons for this incremental policy development. First, it took time for the Commission to thoroughly investigate member states' existing and new complex schemes of economic assistance to industries in various sectors. Second, many member states were generally resistant to the strict enforcement of EU state aid law because they regarded state aid as a key instrument for national industrial policies and other socioeconomic policies. Third, the treaty provisions are quite vague, and the clarification of key legal concepts, most notably state aid, required the accumulation of case law over time. Finally, since the Council of Ministers rejected two drafts of a state aid regulation in 1966 and 1972, the European Commission had no choice but to take a soft law approach in its early years (Cini 2001: 199). In other words, in the first few decades, EU state aid control relied heavily on a nameand-shame strategy based on non-coercive measures. It was only in the late 1990s that the Council established legislation on detailed rules for the application of treaty provisions on state aid. The first legislation of this kind was Regulation 659/1999, ${ }^{24}$ which was later replaced by Regulation 2015/1589. Today, hard law such as regulations and the European Commission's soft law constitute the EU's state aid rules.

The EU's state aid policy, discussed in greater detail in Chapter 3, has faced significant challenges since the late 2000s. The global financial crisis of 20072008 caused the EU to relax its state aid rules as a temporary solution. After a few years, the European Commission once again began to ensure strict law 
enforcement. Since 2013, the Commission has tackled the issue of tax benefits granted by member states to large multinational corporations. Between 2015 and 2019, the Commission made eight decisions related to taxation, showing its determination to address this highly controversial issue. However, this period of proactive state aid control was rather short. The outbreak of coronavirus disease has posed one of the biggest challenges yet to the EU's state aid control. European economies have been severely impacted by the pandemic. Consequently, the Commission has faced a flood of urgent state aid notifications from member states since 2020. This is a reminder that state aid control is particularly sensitive to economic crises compared to other areas of competition policy.

In summary, the four areas of EU competition policy have similarities and differences. There are two main similarities. First, all areas developed incrementally over time. Key legal concepts have been clarified by case law, and detailed procedural rules have been laid down in secondary law such as regulations. Second, the European Commission is now equipped with strong coercive measures in all areas, most notably financial penalties. Table 2.2 summarises these coercive measures. With regard to differences, the European Commission and member states clash more frequently in merger and state aid control than in other areas. It is also noteworthy that each policy area faces distinctive challenges. The fight against cartels is the top priority in the area of restrictive practices, whereas the regulation of information technology companies is a major issue in the area of abuse of dominance. In the area of mergers, firms and member state governments often criticise the Commission for failing to consider non-competition objectives, such as industrial policy concerns. Another major issue in this area is the risk of interjurisdictional conflicts with non-EU countries, although such conflicts do not occur frequently. In the area of state aid, the Commission has recently taken a proactive approach to the issue of national tax rulings, but several Commission decisions have been overturned by the EU courts. In addition, state aid control has been most severely affected by the global financial crisis and the current economic crisis caused by the pandemic. The empirical research in the following chapters considers these differences across policy areas.

TABLE 2.2 The European Commission's key coercive measures in its competition policy

\begin{tabular}{llll}
\hline Policy areas & \multicolumn{2}{c}{ Types of decisions } & Financial penalties \\
\hline Restrictive practices & Commitment decisions & Prohibition decisions & $\begin{array}{c}\text { Fines on firms } \\
\text { Abuse of dominance }\end{array}$ \\
Mergers & $\begin{array}{c}\text { Commitment decisions } \\
\text { Conditional approval } \\
\text { (Phase I and Phase II) }\end{array}$ & $\begin{array}{l}\text { Prohibition decisions } \\
\text { Prohition decisions }\end{array}$ & $\begin{array}{l}\text { (Phase II) } \\
\text { their worldwide }\end{array}$ \\
State aid & Negative decisions & The recovery of aid & $\begin{array}{c}\text { Fines on } \\
\text { member states }\end{array}$ \\
\hline
\end{tabular}




\subsection{Legal and political basis for extraterritorial jurisdiction and external relations}

The EU's actorness and presence in international competition relations have developed over time, especially since the 1990s. On the one hand, the EU plays the role of a 'market power' in this policy field (Damro 2012). A market power is an international actor that intentionally and unintentionally externalises its socioeconomic regulations to other countries and international institutions while shaping the behaviour of firms with coercive measures and the attractiveness of access to its large market. On the other hand, the EU actively engages with other countries in this area at bilateral and multilateral levels. These aspects, namely, global regulatory influence and external relations, constitute the EU's external competition policy.

With regard to global regulatory influence, the EU applies its competition law not only within the European single market but also beyond its borders. This is not obvious. On the contrary, it is a result of the incremental development of case law over the past five decades. As with many other jurisdictions, the EC lacked a clear legal basis for the international enforcement of competition law in its early years. Therefore, the EC mainly applied its competition law to economic activities within member states. However, the gradual development of case law since the 1970s allowed the EC to adopt an approach based on the idea of 'extraterritoriality' as opposed to the principle of territoriality in public international law. The EC adopted an approach based on extraterritoriality to cope with the emerging global economy that involved anticompetitive business practices across jurisdictions. The case law accumulated further after the EU was established. Today, the extraterritorial application of competition rules is one of the EU's major policy instruments to regulate non-EU firms.

Case law concerning the extraterritorial application of competition law was first developed in the United States (Dabbah 2010: 432-452; Jones and Sufrin 2016: 1210-1218). The US Supreme Court established the 'effects doctrine' in the Alcoa judgement ${ }^{25}$ as early as 1945 . The Alcoa case concerned a cartel of Swiss aluminium producers. A key question in this case was whether US antitrust law applies to cartels operated outside the country. The court ruled that the Sherman Antitrust Act is applicable to business practices conducted outside the United States, if they have adverse effects on its economy. The Foreign Trade Antitrust Improvements Act of 1982 elaborated on this point and established that US antitrust law applies to foreign commerce that has 'direct, substantial, and reasonably foreseeable' effects on competition in the American market. This formulation of the effects doctrine was confirmed by judgements on cases such as Hartford Fire Insurance. ${ }^{26}$ Furthermore, there were two major developments in the 1990s. First, in the Nippon Paper case, ${ }^{27}$ the court upheld the US government's first application of the effects doctrine to criminal proceedings against the breach of antitrust law. This case involved a Japanese firm, Nippon Paper, which participated in a cartel concerning the price of fax paper sold to the American 
market. The US government brought a criminal prosecution against the executives of this firm, although the cartel was entirely conducted outside the country. Second, the government decided to apply its antitrust law against foreign economic activities that negatively affect US exporters' interests, even if these activities do not directly affect the American market (Dabbah 2010: 451). As these cases illustrate, the United States defines the effects doctrine very broadly. Unsurprisingly, such an approach to competition law enforcement is widely considered unilateral and confrontational, and has caused interjurisdictional conflicts at times. Nevertheless, the United States has inspired many competition authorities and courts, including that of the EU, by demonstrating how to put the idea of extraterritoriality into practice.

The extraterritorial application of EU competition law is underpinned by three main legal concepts, namely, the 'single economic entity doctrine', the 'implementation doctrine', and the 'qualified effects doctrine' (Jones and Sufrin 2016: 1219-1233). The single economic entity doctrine concerns the issue of parental liability and was established by the ICI v. Commission (Dyestuffs) judgement of the European Court of Justice in 1972. ${ }^{28}$ This judgement concerned the European Commission's decision on an international cartel involving dye manufacturers. The cartel participants included a British firm, ICI; the United Kingdom had not yet joined the EC. After being fined by the Commission, ICI appealed to the court and argued that the Commission had no power to apply its competition law to firms established outside the EC. The Commission made two arguments to justify its decision. One of the arguments rested on the effects doctrine, whereas the other was based on a new concept that would be named the implementation doctrine. Based on the latter, the Commission stated that ICI effectively controlled the management of its subsidiaries in the European common market and should therefore be held responsible for their activities. The court did not clarify its position on the effects doctrine, but supported the Commission's justification of its decision based on the implementation doctrine. This judgement is significant because it established that parent companies based outside the EU (then the EC) are in principle responsible for the anticompetitive business practices of their subsidiaries in the EU market. ${ }^{29}$ The implementation doctrine is based on the idea that the parent company and its subsidiaries together constitute a 'single economic entity' under EU competition law. This doctrine particularly matters for non-EU firms. They need to ensure that their subsidiaries in EU member states comply with EU competition law. It is also important to note that the global and European turnovers of parent companies are taken into consideration when the Commission calculates fines on their European subsidiaries.

The implementation doctrine is another important basis for the EU's extraterritorial application of competition law. According to this doctrine, EU competition law applies to anticompetitive business practices that have been 'implemented' in the EU market regardless of the location of firms' registered offices and production sites. In other words, even firms that do not physically 
exist in Europe could be subject to EU competition law. This doctrine was established by the Wood Pulp judgement of the European Court of Justice in 1988. ${ }^{30}$ The judgement concerned an international cartel among wood pulp producers and associations of wood pulp producers based in four non-EC countries, namely, the United States, Canada, Sweden, and Finland. While the producers had headquarters outside the EC, the European Commission imposed fines on them on the grounds that their cartel had a negative impact on the EC market through direct export and sales by their European subsidiaries. The firms claimed that the European Commission's decision was incompatible with public international law because the conduct was agreed upon outside the EC. They also claimed that the Commission had no power to interfere in the case because the court did not adopt the effects doctrine in the Dyestuffs judgement. However, the court upheld the Commission's decision based on a threefold argument (paragraph 16). First, it is important to distinguish between two elements, namely, where anticompetitive conduct is agreed, and where it is implemented. Second, firms can easily evade EC competition law if its applicability depends on the first element, that is, where the agreement is formed. Finally, ' $\mathrm{t}$ ] he decisive factor is therefore the place where it is implemented' (paragraph 16). In this way, instead of adopting the effects doctrine developed in the United States, the European Court of Justice established its own concept, the implementation doctrine. ${ }^{31}$ The judgement significantly expanded the territorial scope of the EC's jurisdiction.

While the Dyestuffs and Wood Pulp judgements concerned cartels, the issue of extraterritoriality is also relevant to merger control. As explained in the previous section, the EU has exclusive jurisdiction over mergers with an EU dimension, and Article 1 of Regulation 139/2004 defines thresholds for the EU dimension in terms of merging firms' worldwide and EU-wide turnover. This rule applies regardless of the location of their headquarters. Therefore, mergers may be subject to EU competition law, even if they exclusively involve non-EU firms. This issue arose in the controversial judgement of the Court of First Instance on Gencor v. Commission in 1999. ${ }^{32}$ This judgement concerned the European Commission's disapproval of a notified transaction between Gencor of South Africa and Lonrho of the United Kingdom. The proposed operation involved two steps. First, Gencor and Lonrho acquire joint control of Implats, a South African firm holding all of Gencor's platinum group metal mining and refinement operations. Second, Implats acquires sole control of two South African firms, Eastern Platinum and Western Platinum, holding all of Lonrho's platinum business. The notified operation was approved by the South African Competition Board. However, the European Commission disapproved this operation on the grounds that it would create an oligopoly in the platinum and rhodium industries. Gencor appealed to the Court of First Instance and complained that the European Commission had no jurisdiction over the case. Specifically, Gencor said it was wrong for the Commission to intervene in this case based on the implementation doctrine because all production facilities of Implats, Eastern Platinum, and Western Platinum were outside the EC, and 
the proposed operation would also be implemented outside the EC. The court rejected this complaint and upheld the Commission's prohibition decision. In paragraph 87 of the judgement, the court ruled the following:

According to Wood Pulp, the criterion as to the implementation of an agreement is satisfied by mere sale within the Community, irrespective of the location of the sources of supply and the production plant. It is not disputed that Gencor and Lonrho carried out sales in the Community before the concentration and would have continued to do so thereafter.

Although the court emphasised the consistency between the judgement and case law in those sentences, many commentators suspected that the judgement departed from the implementation doctrine in a significant way. In the judgement, in order to ascertain the compatibility between the European Commission decision and public international law, the court examined whether the proposed concentration had an 'immediate, substantial and foreseeable effect' on the European common market (paragraph 92). The logic and specific words used in the judgment indicated that the court adopted an approach quite similar to the effects doctrine (Dabbah 2010: 457-460).

The 'qualified effects' doctrine is the third and most recent legal basis for the EU's extraterritorial jurisdiction. This doctrine was established by the General Court's Intel judgement of $2014^{33}$ and confirmed by the Court of Justice of the EU in 2017. ${ }^{34}$ The Intel case concerned the abuse of dominance under Article 102 of the TFEU. In 2009, the European Commission imposed a record-breaking fine of 1.06 billion euros on an American firm, Intel, for abusing its dominant position in the semiconductor industry. ${ }^{35}$ In its decision, the European Commission stated that Intel aimed to exclude the products of its main rival, AMD, from the market by using two strategies. First, Intel paid loyal rebates to computer manufacturers that used its product, namely, central processing units. Second. Intel requested that manufacturers cancel contracts with AMD regarding the purchase of central processing units while paying compensation fees that AMD imposed on the manufactures. The manufacturers included Lenovo and Acer, whose production facilities were in China and Taiwan, respectively. Intel appealed to the General Court and, inter alia, challenged the EU's jurisdiction over the transaction with Lenovo and Acer. According to Intel, the implementation doctrine was irrelevant in this case because the conduct was exclusively implemented outside the EU's territory, and few of the products concerned were exported to the EU market. Furthermore, the effects doctrine had not been explicitly adopted in EU competition law. Therefore, Intel argued that the European Commission had no power to assert jurisdiction over the case. In its judgement in 2014, the General Court rejected Intel's complaint and fully supported the European Commission's decision. The court referred to the Gencor judgement and stated that it relied heavily on the qualified effects doctrine, according to which the EU exercises jurisdiction over business activities when 
it is foreseeable that they will have an immediate and substantial effect on the EU market, even if these activities are conducted by non-EU firms with no production facilities and offices in EU territory (paragraphs 233 and 240). In 2017, the Court of Justice rejected the General Court's judgement in several respects and referred the case back to the General Court. That being said, the Court of Justice largely upheld the judgement regarding the use of the qualified effects doctrine as the basis for the EU's jurisdiction (paragraphs 40-47). ${ }^{36}$ There is criticism of these judgements by EU courts. An opinion of Advocate General Nils Wahl is particularly noteworthy concerning the issue of jurisdiction (Fox 2019: 984-992). The Advocate General did not deny the importance of an effectsbased approach, but criticised the General Court for failing to demonstrate that Intel's conduct would have a substantial, immediate, and foreseeable effect on the EU market. ${ }^{37}$ Although his criticism may be convincing, it does not undermine the importance of these judgements. They represented an important milestone for EU competition policy because, in these judgements, EU courts explicitly acknowledged the qualified effects doctrine as one of the legal bases to establish the EU's extraterritorial jurisdiction.

Overall, the three doctrines have significantly expanded the EU's jurisdiction. They have laid the foundation for the EU's emergence as one of the most powerful competition regulators in the world. That being said, the development of the EU's extraterritorial jurisdiction has been a source of occasional but serious political friction with other economies. Extraterritoriality is a politically sensitive issue because it may impinge on the sovereignty of other countries. For this reason, the EU has been interested in competition cooperation with major economic partners, especially the United States, to reduce the risk of interjurisdictional conflicts that derive from differences in national and regional competition rules and their extraterritorial applications.

The EU has concluded various types of competition-related agreements with major world economies (Demedts 2018; Papadopoulos 2010). These agreements include 'competition cooperation agreements' that aim to enhance information exchange and the coordination of investigations between competition authorities. The European Commission's competence to conclude these international agreements is not obvious; it was contested by the French government (Damro 2006: 109-113). The European Commission signed its first competition cooperation agreement with the United States in 1991. When the Council of Ministers adopted its first merger rule (Regulation 4064/89) in 1989, the risk of interjurisdictional conflicts between the EC and the United States increased. Hence, EC and US competition authorities signed an agreement to minimise such risk (Klein 2000). Subsequently, the French government appealed to the European Court of Justice and claimed that the European Commission breached EC law by concluding the agreement. According to France, the Council of Ministers retained the power to conclude international competition agreements, and the European Commission only had the competence to negotiate based on the Council's authorisation. The European Commission responded that the agreement with 
the United States was not a treaty, but a non-binding administrative agreement that did not require the Council's authorisation. However, the court rejected the European Commission's defence and decided that competition agreements had to be concluded by the Council rather than the Commission. ${ }^{38}$ The EU-US agreement ultimately entered into force with amendments after the Council of Ministers accepted communication from the European Commission, and the two issued a joint decision in 1995. ${ }^{39}$ This political settlement paved the way for the EU's external competition relations based on competition cooperation agreements. As discussed in greater detail in Chapter 5, the EU also signed free trade agreements (FTAs) with competition provisions with some countries while actively participating in competition-related multinational institutions, such as the ICN, the OECD, and UNCTAD.

\section{Conclusion}

This chapter presented three key findings. First, the European Commission possesses strong investigative and decision-making powers in EU competition policy, although its law enforcement system has been decentralised to a certain extent since modernisation reforms in 2004. Second, the four sub-fields of EU competition policy developed at different speeds and face different challenges, but the European Commission is now equipped with strong legal measures, especially financial penalties, in all sub-fields of this policy. Third, while EU competition policy originally focused on its internal aspects, a legal basis for extraterritorial jurisdiction has incrementally developed through case law. Furthermore, the European Commission started to proactively build external competition relations in the 1990s. Building on these findings, Chapters 3, 4, and 5 examine how the EU is coping with the competition-competitiveness dilemma internally and externally.

\section{Notes}

1 For more details about the treaty negotiations and the role of a transatlantic network of elites, see Leucht (2009).

2 Directive 2014/104/EU of the European Parliament and of the Council of 26 November 2014 on certain rules governing actions for damages under national law for infringements of the competition law provisions of the Member States and of the European Union, OJ L349/1, 5 December 2014.

3 Council Regulation (EC) No 1/2003 of 16 December 2002 on the implementation of the rules on competition laid down in Articles 81 and 82 of the Treaty, OJ L1/1, 4 January 2003.

4 Directive (EU) 2019/1 of the European Parliament and of the Council of 11 December 2018 to empower the competition authorities of the Member States to be more effective enforcers and to ensure the proper functioning of the internal market, OJ L11/3, 14 January 2019.

5 Commission Notice on the conduct of settlement procedures in view of the adoption of Decisions pursuant to Article 7 and Article 23 of Council Regulation (EC) No 1/2003 in cartel cases, OJ C167/1, 2 July 2008. 
6 Joined cases 56 and 58/64, Consten and Grundig v. Commission, ECLI:EU:C:1966:41.

7 Commission Notice on Immunity from fines and reduction of fines in cartel cases, OJ C298/17, 8 December 2006.

8 Guidelines on the method of setting fines imposed pursuant to Article 23(2)(a) of Regulation No 1/2003, OJ C210/2, 1 September 2006.

9 Case IV/26.760, Gesellschaft für musikalische Aufführungs- und mechanische Vervielfältigungsrechte (GEMA), Commission decision of 2 June 1971, OJ L134/15, 20 June 1971.

10 Case C-27/76, United Brands v. Commission, ECLI:EU:C:1978:22; Case C-85/76, Hoffmann-La Roche v. Commission, ECLI:EU:C:1979:36.

11 Case T-68/89, SIV v. Commission, ECLI:EU:T:1992:38.

12 Case COMP/C-3/37.792, Microsoft.

13 Case AT.39530, Microsoft (Tying).

14 Case COMP/C-3/37.990, Intel.

15 Cases AT.39740, Google Search (Shopping); AT.40099, Google Android; and AT.40411, Google Search (AdSense).

16 Case T-342/99, Airtours plc v. Commission, ECLI:EU:T:2002:146; Case T-310/01, Schneider Electric SA v. Commission, ECLI:EU:T:2002:254; Case T-5/02 and T-80/02, Tetra Laval v. Commission, ECLI:EU:T:2002:264.

17 Guidelines on the assessment of horizontal mergers under the Council Regulation on the control of concentrations between undertakings, (2004/C 31/03), OJ C31/5, 5 February 2004.

18 Council Regulation (EC) No 139/2004 of 20 January 2004 on the control of concentrations between undertakings (the EC Merger Regulation), OJ L24/1, 29 January 2004.

19 Articles 9 and 22 of Council Regulation 139/2004 provide a referral mechanism which allows the Commission and member states to transfer competition cases between themselves under certain conditions, but this mechanism is not frequently used.

20 Commission Regulation (EU) No 651/2014 of 17 June 2014 declaring certain categories of aid compatible with the internal market in application of Articles 107 and 108 of the Treaty, OJ L187/1, 26 June 2014.

21 Commission Notice on the notion of state aid as referred to in Article 107(1) of the Treaty on the Functioning of the European Union (2016/C 262/01), OJ C262/1, 19 July 2016.

22 Council Regulation (EU) 2015/1589 of 13 July 2015 laying down detailed rules for the application of Article 108 of the Treaty on the Functioning of the European Union, OJ L248/9, 24 September 2015.

23 Case 70/72, Commission v. Germany, ECLI:EU:C:1973:87.

24 Council Regulation (EC) No 659/1999 of 22 March 1999 laying down detailed rules for the application of Article 93 of the EC Treaty, OJ L83/1, 27 March 1999.

25 United States v Aluminium Co. of America (Alcoa), 148 F.2d 416 (2d Cir. 1945).

26 Hartford Fire Insurance Co. v. California, 509 US 764, 113 S.Ct. 2891 (1993).

27 United States v Nippon Paper Industries Co., 109 F.3d 1 (1st Cir. 1997).

28 Case 48/69, ICI v. Commission (Dyestuffs), ECLI:EU:C:1972:70.

29 To be precise, when a company has a 100\% shareholding in its subsidiary, the former shall be liable for the latter's conduct. When a company holds some of its subsidiary's shares, the European Commission ascertains whether the former has effective control of the latter's conduct (Lorenz 2013: 338-339).

30 Joined Cases 89, 104, 114, 116, 117, and 125 to 129/85, A. Ahlström Osakeyhtiö and others v. Commission (Wood Pulp), ECLI:EU:C:1988:447.

31 There are studies on the question of whether EU and US approaches really differ substantially. See Dabbah (2010: 461-469).

32 Case T-102/96, Gencor Ltd v. Commission, ECLI:EU:T:1999:65.

33 T-286-09, Intel v. Commission, ECLI:EU:T:2014:547.

34 C-413/14 P, Intel v. Commission, ECLI:EU:C:2017:632. 
35 COMP/C-2/37.990, Intel, Commission Decision of 13 May 2009.

36 See Zelger (2020) for more details.

37 Opinion of Advocate General Wahl, C-413/14 P, Intel Corp. v. Commission, ECLI:EU:C:2016:788, paras 324-327.

38 Case C-327/91, French Republic v. Commission of the European Communities, ECLI:EU:C:1994:305.

39 Decision of the Council and the Commission of 10 April 1995 concerning the conclusion of the Agreement between the European Communities and the Government of the United States of America regarding the application of their competition laws, OJ L95/45, 27 April 1995.

\section{References}

Blauberger, M. (2009). Of 'Good' and 'Bad' Subsidies: European State Aid Control Through Soft and Hard Law. West European Politics, 32(4), pp. 719-737.

Buch-Hansen, H. and Wigger, A. (2011). The Politics of European Competition Regulation: A Critical Political Economy Perspective. Abingdon: Routledge.

Büthe, T. (2007). The Politics of Competition and Institutional Change in the European Union: The First Fifty Years. In: S. Meunier and K. McNamara (eds), Making History: European Integration and Institutional Change at Fifty. Oxford: Oxford University Press, pp. 175-193.

Cini, M. (2001). The Soft Law Approach: Commission Rule-Making in the EU's State Aid Regime. Journal of European Public Policy, 8(2), pp. 192-207.

Cini, M. and McGowan, L. (2009). Competition Policy in the European Union, 2nd ed. Basingstoke: Palgrave Macmillan.

Dabbah, M. M. (2010). International and Comparative Competition Law. Cambridge: Cambridge University Press.

Damro, C. (2006). Cooperating on Competition in Transatlantic Economic Relations: The Politics of Dispute Prevention. Basingstoke: Palgrave Macmillan.

Damro, C. (2012). Market Power Europe. Journal of European Public Policy, 19(5), pp. 682-699.

Demedts, V. (2018). The Future of International Competition Law Enforcement: An Assessment of the EU's Cooperation Efforts. Boston: Brill.

EURACTIV. (2019). Agriculture DG Loses State Aid Oversight to Boost Competition Rules. 16 September.

European Commission. (1958). The First General Report on the Activities of the Community, European Economic Community.

European Commission. (1985). Completing the Internal Market: White Paper from the Commission to the European Council, COM(85)310 final.

European Commission. (2011). Report on Competition Policy 2010, COM(2011)328 final.

European Commission. (2013a). Competition: Antitrust Procedures in Anticompetitive Agreements [Online]. Available at: https://ec.europa.eu/competition/publications/ factsheets/antitrust_procedures_101_en.pdf [accessed: 31 March 2021].

European Commission. (2013b). Competition: Antitrust Procedures in Abuse of Dominance [Online]. Available at: https://ec.europa.eu/competition/publications/ factsheets/antitrust_procedures_102_en.pdf [accessed: 31 March 2021].

European Commission. (2013c). Competition: Merger Control Procedures [Online]. Available at: https://ec.europa.eu/competition/publications/factsheets/merger_ control_procedures_en.pdf [accessed: 31 March 2021]. 
European Commission. (2013d). Competition: State Aid Procedures [Online]. Available at: https://ec.europa.eu/competition/publications/factsheets/state_aid_procedures_ en.pdf [accessed: 31 March 2021].

European Commission. (2017). 'Antitrust: Commission Proposal to Make National Competition Authorities Even More Effective Enforcers for the Benefit of Jobs and Growth', Press Release, IP/17/685.

Fox, E. M. (2019). Extraterritorial Jurisdiction, Antitrust, and the EU Intel Case: Implementation, Qualified Effects, and the Third Kind. Fordham International Law Journal, 42(3), pp. 981-997.

Gerber, D. J. (1994). The Transformation of European Community Competition Law. Harvard International Law Journal, 35(1), pp. 87-95.

Gerber, D. J. (2010). Global Competition: Law, Markets and Globalization. Oxford: Oxford University Press.

Goyder, J. and Albors-Llorens, A. (2009). Goyder's EU Competition Law. 5th ed. New York: Oxford University Press.

Jones, A. and Sufrin, B. (2016). EU Competition Law: Text, Cases, and Materials. 6th ed. Oxford: Oxford University Press.

Klein, J. L. (2000). Time for a Global Competition Initiative? Speech at the EC Merger Control 10th Anniversary Conference, Brussels, 14 September [Online]. Available at: https://www.justice.gov/atr/speech/time-global-competition-initiative [accessed: 31 March 2021].

Leucht, B. (2009). Transatlantic Policy Networks in the Creation of the First European Anti-Trust Law: Mediating between American and Anti-Trust and German OrdoLiberalism. In: W. Kaiser, B. Leucht and M. Rasmussen (eds), The History of the European Union: Origins of a Trans- and Supranational Policy 1950-72. Abingdon: Routledge, pp. 56-73.

Levy, N. (2005). Mario Monti's Legacy in EC Merger Control. Competition Policy International, 1(1), pp. 99-132.

Lorenz, M. (2013). An Introduction to EU Competition Law. Cambridge: Cambridge University Press.

Majone, G. (1996). The European Commission as Regulator. In: G. Majone (ed), Regulating Europe. London: Routledge, pp. 61-79.

McCann, D. (2010). The Political Economy of the European Union. Cambridge: Polity Press.

McGowan, L. (2010). The Antitrust Revolution in Europe: Exploring the European Commission's Cartel Policy. Cheltenham: Edward Elgar.

McGowan, L. and Cini, M. (1999). Discretion and Politicization in EU Competition Policy: The Case of Merger Control. Governance, 12(2), pp. 175-200.

Pace, L. F. and Seidel, K. (2013). The Drafting and the Role of Regulation 17: A HardFought Compromise. In: K. K. Patel and H. Schweitzer (eds), The Historical Foundations of EU Competition Law. Oxford: Oxford University Press, pp. 54-88.

Papadopoulos, A. S. (2010). The International Dimension of EU Competition Law and Policy. Cambridge: Cambridge University Press.

Svetiev, Y. (2010). Networked Competition Governance in the EU: Delegation, Decentralization, or Experimentalist Architecture? In: C. F. Sabel and J. Zeitlin (eds), Experimentalist Governance in the European Union: Towards a New Architecture. Oxford: Oxford University Press, pp. 79-120.

Von der Groeben, H. (1985). The European Community: The Formative Years: The Struggle to Establish the Common Market and the Political Union. Luxembourg: Office for Official Publications of the European Communities. 
Warlouzet, L. (2016). The Centralization of EU Competition Policy: Historical Institutionalist Dynamics from Cartel Monitoring to Merger Control (1956-91). Journal of Common Market Studies, 54(3), pp. 725-741.

Wilks, S. (2005). Agency Escape: Decentralization or Dominance of the European Commission in the Modernization of Competition Policy? Governance, 18(3), pp. 431-452.

Wilks, S. (2010). Competition Policy: Towards an Economic Constitution? In: H. Wallace, M. A. Pollack and A. R. Young (eds), Policy-Making in the European Union, 6th ed. Oxford: Oxford University Press, pp. 133-155.

Wilks, S. and McGowan, L. (1996). Competition Policy in the European Union: Creating a Federal Agency? In: G. B. Doern and S. Wilks (eds), Comparative Competition Policy: National Institutions in a Global Market. Oxford: Clarendon Press, pp. 225-267.

Zelger, B. (2020). EU Competition Law and Extraterritorial Jurisdiction: A Critical Analysis of the ECJ's Judgement in Intel. European Competition Journal, 16(2-3), pp. 613-627. 


\section{3}

\section{TENSION BETWEEN STRINGENT SUPRANATIONAL REGULATIONS AND NATIONAL NEO-MERCANTILISM}

This chapter explores the proposition that supranationally institutionalised competition policies, such as that of the EU, prioritise the promotion of market competition over the enhancement of local firms' international competitiveness. For this purpose, this chapter examines two sub-fields of EU competition policy: merger and state aid. Research shows that these policy areas are a frequent source of disagreement between national and supranational competition authorities about a balance between market competition and industrial competitiveness (Cini and McGowan 2009: 222). To ascertain which goal takes precedence in practice, Section 1 analyses selected merger cases in three politically sensitive sectors: motor vehicles, rail transport, and energy. Section 2 studies the global financial crisis in 2007-2008 and its aftermath to examine how sensitive the EU has been to mounting political pressure from member state governments to relax state aid rules.

\subsection{Clashes between national and supranational authorities in merger cases}

Concerning the internal aspects of EU competition policy, merger control provides a good test of how the European Commission deals with the competition-competitiveness dilemma. Unlike cartels, mergers are not inherently illegal. Conversely, they are typical business activities and can potentially improve economic efficiency. However, the European Commission blocks mergers that are likely to create or strengthen dominant market positions. Such supranational actions for the maintenance of market competition may contradict member state governments' attempts to foster larger, internationally competitive firms. The Commission and member states may also disagree about merger cases in the opposite direction. The Commission generally favours cross-border mergers 
because they contribute to regional economic integration. Conversely, some member states have tried to hinder cross-border mergers for protecting large firms based in their own countries, especially former state-owned monopolies. The key issue in both kinds of conflicts is the balance between two policy goals: the promotion of market competition and the creation of larger EU firms.

Thatcher (2014) studied the relationship between EU merger control and the creation of larger European firms. He examined merger cases in the banking, energy, and telecommunications sectors to ascertain whether EU competition policy was as 'merger-constraining' as was often said. He found that the European Commission cleared a vast majority of merger notifications since the EU gained authority to regulate mergers in 1990. Between 1990 and 2009, the Commission reviewed around 600 merger cases in the three sectors and unconditionally approved most of them, except for 37 cases. Twenty-two of the cases were approved in Phase I with conditions. 13 cases were approved in Phase II, and only 2 cases were disapproved. Furthermore, he found that many cases approved by the Commission involved large European firms that were widely regarded as national champions. Based on these observations, Thatcher concludes that the Commission pursues an 'integrationist policy' that achieves three goals: promotion of competition, regional market integration, and the creation of larger EU firms.

Thatcher's concept of 'integrationist policy' as opposed to 'merger-constraining' policy has both merits and limitations. On the positive side, the concept of integrationist policy is useful in explaining the general trends of EU merger control. As he observes, the European Commission approves most cases unconditionally, and EU merger control does not always obstruct the development of larger EU firms. For example, mergers between large firms may be approved if there is little overlap between their businesses in terms of products and geographic markets. On the negative side, the concept is not useful in explaining why the European Commission and member states at times have serious conflicts with each other over merger cases.

This book proposes to use the concepts of stringent and strategic competition policies to explain these conflicts, which are relatively rare but important politically and economically. The following empirical research shows that EU merger control has the characteristics of a 'stringent competition policy' that is nondiscriminatory and comparatively strict. That is why it sometimes clashes with the 'strategic competition policies' of some member states that prioritise the creation of larger firms rather than the maintenance of competition in the EU market.

To ascertain whether the European Commission's merger control is stringent rather than strategic, the following analysis focuses on three issues: (1) market definitions, (2) international competitiveness, and (3) national governments' obstruction of foreign takeovers. Regarding the first issue, the calculation of market share is crucial for merger control. If firms have higher market shares in certain markets, their mergers are more likely to be blocked by competition authorities. Market share largely depends on the definition of the relevant 
products and geographic markets. The latter is a particularly sensitive issue in the EU because the degree of regional economic integration varies across sectors. If geographic markets are broadly defined, the merging firms' market shares are usually lower, and their mergers are more likely to be approved. Therefore, if EU merger control is strategic, geographic markets would be defined relatively broadly. Conversely, if the policy is stringent, geographic markets would be defined more narrowly. The second major issue is the international competitiveness of EU firms. If EU merger control is strategic, the European Commission would permit mergers on the grounds of international competitiveness, even if they significantly constrain competition in the EU market. Conversely, if the policy is stringent, the Commission would make decisions based solely on the competition criteria (i.e. whether mergers create or strengthen dominant market positions). The third issue is that some member states try to obstruct the takeovers of large domestic firms by competitors from other member states. Such actions can be regarded as discrimination based on the nationality of the firms. Therefore, it would cause conflicts between member states and the Commission, if the latter pursues a stringent competition policy. Such conflicts may also involve the matter of jurisdiction over cross-border merger cases.

To test whether EU merger control has the characteristics of stringent competition policy in these aspects, the following part conducts three case studies: Volvo/Scania (1999-2000), Siemens/Alstom (2018-2019), and E.ON/Endesa (2006). These cases were selected for three reasons. First, all of them were highly politicised because of fundamental disagreements between the European Commission and certain member state governments. The controversies over these cases help to understand the position of the Commission, which is not always apparent in the EU's general policy documents and legislation. Second, the cases represent politically sensitive sectors: motor vehicles, rail transport, and energy. They are politically sensitive because the first one is in the high-tech sector, and the others concern infrastructure that is essential for national economies. Third, these cases are directly relevant to the three key issues in EU merger control mentioned above. Volvo/Scania, which was blocked by the Commission, provides a good test of whether the Commission defines geographic markets relatively broadly. The Swedish firms, Volvo and Scania, produced trucks, coaches, and buses, mainly in northern European countries, but their market shares were lower in other EU member states. The Commission's disapproval of the proposed merger between Siemens (Germany) and Alstom (France) caused heated debate about the relationship between competition and industrial policies. One of the main objectives of this merger was to create a large European firm that could compete with American and Chinese rivals. Therefore, this case helps to understand whether the Commission considers the issue of international competitiveness in merger reviews. The public bid by E.ON (Germany) for Endesa (Spain) concerned the problem of national governments' obstruction of foreign takeovers. The Commission approved this transaction, but the Spanish government intervened to protect Endesa, the largest Spanish electricity company. 
Each case study consists of three elements. First, it provides a chronological description of the case, focusing on the European Commission's investigation and the merging firms' responses. Second, it analyses the case from a political perspective. Finally, it reflects on whether the Commission's decision can be explained from the stringent competition policy perspective. The case studies are based on numerous sources, such as the European Commission's decisions and press releases, European Competition Commissioners' speeches, European and non-European newspapers, and academic studies.

\subsubsection{Volvo/Scania: the politics of market definitions}

Volvo/Scania is a merger case between 1999 and 2000 that involved two leading Swedish manufacturers with similar product portfolios. While Volvo primarily produced trucks, buses, construction equipment, marine and industrial engines, and aerospace components, Scania was mainly active in the market for heavy trucks (i.e. trucks above 16 tonnes), buses, and marine and industrial engines (European Commission 1999). In 1999, Volvo searched for a business partner to strengthen its competitiveness in relation to its European and American rivals. It sold its automobile business to Ford in March and concentrated on the production of trucks, buses, and engines. After months of negotiation, Volvo agreed to purchase the majority stake of Investor (Sweden) in Scania for 60.7 billion kronor (nearly 7 billion euros), aiming to become the largest maker of heavy trucks and buses in the European market and the second-largest worldwide after DaimlerChrysler of Germany (Latour 1999). On 22 September 1999, Volvo officially notified the European Commission of its plan to acquire Scania. At that time, Volvo's Chief Executive Leif Johansson was confident that the European Commission would approve the merger (Miller and Lindroth 2000).

Much to Volvo's surprise, the European Commission expressed serious concerns about the proposed merger and launched an in-depth investigation on 25 October 1999 because the initial investigation showed that the proposed acquisition could lead to the creation of oligopolies in several markets. After an in-depth investigation, the European Commission (2000a) concluded that the transaction would create dominant positions in the following areas:

- the market for heavy trucks in Finland, Ireland, Norway, and Sweden;

- the market for touring coaches in Finland and the United Kingdom;

- the market for inter-city buses in Denmark, Finland, Norway, and Sweden;

- the market for city buses in Denmark, Finland, Ireland, Norway, and Sweden.

The Commission found that Volvo and Scania were the closest competitors in these markets. 'By removing the largest and closest competitor, the merger would therefore significantly change the market structure to the detriment of the customers', the Commission argued. 
To address these concerns, Volvo proposed a set of remedies to the European Commission on 21 February 2020 (European Commission 2000a). They included the opening up of dealer and service networks of Volvo and Scania to other entrants and the divestiture of three bus and coach bodybuilding plants in Denmark and Sweden. Volvo also proposed to make efforts to convince the Swedish government to abolish a technical safety rule applicable to heavy trucks' cabs (the 'cab crash test') because this test was considered one of the major trade barriers to the Swedish truck market. However, the European Commission stated that these measures were insufficient to resolve the competition concerns and pointed out that the cab crash test could only be abolished by the Swedish government.

During the review, the Swedish government pressurised the European Commission to approve the Volvo/Scania merger. The government had political motives for this action (Milner 2000). At that time, the Social Democratic Party of Swedish Prime Minister Göran Persson was planning a meeting to discuss the timing of Sweden's accession into the Eurozone. The government was concerned that the EU's disapproval of the merger could negatively affect the political campaign on the issue of the euro and reinforce Euroscepticism in Sweden. In addition, Prime Minister Persson wanted to protect his country's motor vehicles sector from foreign capital. In mid-February, Persson held an unusual meeting with then European Competition Commissioner Mario Monti and told him that the proposed merger was of 'vital importance' for the Swedish economy. Persson also stated that if the Commission blocked the merger, Volvo or Scania might have to pursue a partnership with a foreign company, causing serious damage to employment in the country (Mitchener 2000). Despite this extensive lobbying by the Swedish government on behalf of Volvo and Scania, the Commission stood by its position and waited for Volvo to make further concessions.

Volvo proposed new remedies on $7 \mathrm{March}$, although the submission deadline had already expired on 21 February. In response, the European Commission stated that Volvo failed to justify this delay and that the new proposal did not address all competition concerns adequately. On 14 March 2000, the Commission made the final decision that the proposed acquisition was incompatible with the EU market. ${ }^{1}$ It was difficult for the College of Commissioners, the highest decisionmaking body in competition cases, to reach an agreement about this case because there was dissent from Nordic members of the Commission and strong lobbying from the Swedish Prime Minister (Winestock 2000). Nevertheless, the European Commissioners ultimately decided to prohibit the merger, following the opinion of DG Competition. This case received widespread media coverage and showed the tough stance of Mario Monti, who became the European Commissioner for Competition just before the beginning of this case.

Volvo strongly opposed the European Commission's opinion during the review, especially regarding the definition of relevant geographic markets. While the Commission was concerned that the merger would create market dominance in northern European countries, Volvo argued that the Commission 
should look across the entire European single market and stop focusing on a particular region in isolation. For example, in the case of heavy trucks, the combined market share of Volvo and Scania was extremely high in a few countries, such as Sweden (around 90\%). However, the share was only around 30\% in many Western European countries (Milner 2000). In its official communication with the Commission, Volvo attempted to show that European truck and bus markets were integrated significantly and should be considered a single market. Volvo emphasised that there were no significant price differences between the member states in the heavy trucks market except for a single country, Sweden (the European Commission's decision, paragraph 35). The Commission responded that the argument was flawed and inconsistent with the data submitted earlier by Volvo itself (paragraphs 45-46). Furthermore, the Commission maintained that the European market for heavy trucks and buses was still nationally fragmented and hard to penetrate due to high barriers to entry, such as national dealer networks and different national technical standards on safety. This observation was based on the analysis of non-price factors, such as customer preferences, national technical requirements, and distribution and service networks.

The debate over the definition of relevant markets continued after the European Commission blocked the merger. Most notably, Prime Minister Persson raised this issue and severely criticised EU merger control. He stated, ' $\mathrm{t}$ ] he present rules are disadvantageous to us since we tend to dominate our market fraction to such a great extent', and '[t]here is a structural error in the EU's competition rules' (quoted by Monti 2001). From his perspective, the EU's tendency to narrowly define geographic markets was particularly disadvantageous to firms in smaller member states such as Sweden. As Swedish firms operated in a relatively small national market, it was difficult for them to expand their business and compete on a global stage without breaking EU competition law. The Swedish Minister for Industry and Communications, Bjorn Rosengren, also expressed concern and commented, 'I hope this will not mean that major Swedish companies cannot merge at a national level in the future' (Winestock 2000). Furthermore, the director of regulatory affairs for the European Automobile Manufacturers Association, Marc Greven, cast doubt on the consistency of the European Commission's arguments. He observed that the Commission often referred to the European single market but focused on national markets in the Volvo/Scania case as if the single market had not existed (Winestock 2000).

Commissioner Monti challenged these views in his speech 'Market definition as a cornerstone of EU competition policy' in Helsinki on 5 October 2001. He denied that EU competition policy discriminated against firms from smaller member states while emphasising that the European Commission used a standard method of defining relevant markets in the Volvo/Scania case. He argued that it was not impossible for firms from smaller member states to become competitive worldwide. For example, they may expand their business abroad or merge with firms operating in other countries (Monti 2001). As this heated debate over the issue of market definitions suggests, merger cases sometimes cause serious 
conflicts between member state governments and the Commission. The underlying question is whether the creation of larger firms should be pursued at the expense of effective competition in the EU market or any substantial part of it.

To comprehensively understand the political implications of Volvo/Scania, one should also examine a subsequent case in the same sector-Volvo/Renault Vehicule Industriels (RVI). RVI was a wholly owned subsidiary of Renault (France). In September 2000, the European Commission approved Volvo's acquisition of RVI under certain conditions. While RVI's product portfolio resembled that of Scania, this transaction was allowed for two main reasons (European Commission 2000b). First, this merger was unlikely to create dominant positions in any EU member state because RVI and Volvo did not have much overlap in terms of geographic markets. Unlike Scania, which directly competed with Volvo, RVI generally complemented Volvo's business. Second, Volvo and RVI made substantial concessions ('commitments') to win the European Commission's approval. For example, the firms promised to remove their close ties to Scania and Iveco (Fiat Group's company in Italy), respectively, within a specific time frame. In addition, they promised to eliminate their overlap in France's bus market. Not surprisingly, the Commission presented its decisions positively. Commissioner Monti made the following statement to justify the Commission's prohibition of the Volvo/Scania merger and the subsequent approval of the Volvo/RVI merger.

Since [the prohibition decision], not only Volvo has teamed up successfully with RVI, also Scania has found an alternative strategic partner in Volkswagen [...]. These transactions will hopefully contribute to the development of a more competitive situation in the European markets for heavy vehicles.

(European Commission 2000b)

While his positive interpretation of the whole story is debatable, these cases have two significant political implications. First, Volvo/Scania showed the EU's commitment to stringent competition regulation. In this case, the European Commission resisted the Swedish government's pressure to allow the emergence of a new national champion. Furthermore, the Commission rejected Volvo's demand that relevant markets should be defined more broadly. These findings indicate that the Commission prioritised the protection of market competition rather than the creation of larger EU firms. Second, Volvo/Scania and Volvo/ RVI illustrated the EU's considerable regulatory influence on the behaviour of firms. As Monti's comment implies, Volvo seems to have learned a lesson from the first case and made more substantial concessions in the second while choosing a merger partner more carefully, considering the EU's stringent competition policy. In other words, the disapproval of Volvo/Scania demonstrated the EU's direct coercive influence on firms, whereas Volvo/RVI showed the EU's longterm influence on their business strategies. 


\subsubsection{Siemens/Alstom: the politics of international competitiveness}

The next case, Siemens/Alstom ${ }^{2}$ involved two leading European manufacturers: Siemens (Germany) and Alstom (France). Alstom is known for the manufacture of TGV (high-speed rail service) trains. Both firms operate globally and offer numerous products and services related to rail transportation. They include rolling stock (especially trains, trams, and metros), rail electrification systems, and rail automation and signalling solutions (European Commission 2018). Siemens/ Alstom makes an interesting case study because it received widespread media coverage and sparked a heated debate in Europe about the future direction of EU merger control. The political salience of this case can be attributed to three major factors. First, Siemens and Alstom are based in two large and politically powerful member states-Germany and France. Second, this case concerned the rail transport industry, which is widely considered essential for the public interest. Third, the case is directly relevant to a key issue in merger control-the tension between competition policy and industrial competitiveness. The following analysis shows why the European Commission blocked the Siemens/Alstom merger and how these firms and the German and French governments reacted to the decision. In essence, the Commission primarily evaluated the potentially restrictive effect of this merger on competition in the EU market. Conversely, Siemens and Alstom, which were supported by the German and French governments, underlined the importance of the proposed merger for competition with American and Chinese rivals.

In June 2018, the European Commission received a notification from Siemens about its plan to acquire sole control of Alstom. This plan was already well known because it had been discussed for years. In September 2017, Siemens and Alstom published a joint press release entitled 'Siemens and Alstom join forces to create a European Champion in Mobility' and announced that they had signed a memorandum of understanding to prepare for the merger. The combined firm would have had an annual revenue of 15.3 billion euros and around 62,300 employees in more than 60 countries (Siemens and Alstom 2017: 2). Henri Poupart-Lafarge, Chairman and Chief Executive Officer of Alstom, celebrated the day by saying that ' $\mathrm{t}$ ]oday is a key moment in Alstom's history, confirming its position as the platform for the rail sector consolidation'. Joe Kaeser, President and Chief Executive Officer of Siemens, stated that the merger was an opportunity for them to create 'a new European champion in the rail industry for the long term' (Siemens and Alstom 2017: 1-2). They believed that the merger had two major merits. First, the operations of Siemens and Alstom were largely complementary in terms of product portfolios and geographic markets. Potential synergistic effects were estimated at 470 million euros per year (Siemens and Alstom 2017: 3). Second, as Kaeser's use of the term 'European champion' indicates, both leaders believed that the merger would enable them to challenge the world's largest train manufacturer, CRRC, based in China (EURACTIV 2017). CRRC itself was a product of the 2014 merger of two state-owned firms. 
Despite the enthusiasm of both firms, the merger plan faced opposition from the European Commission. Based on an initial assessment, the European Commission decided to open an in-depth investigation into the merger on 13 July 2018. The Commission was particularly concerned about the merger's effect on competition in two markets (European Commission 2018). The first is the market for mainline and urban signalling systems that are used to prevent train, metro, and tram collisions. The second is the market for high-speed, mainline, and urban rolling stock. High-speed rolling stock includes trains for longdistance travel, and mainline rolling stock includes intercity and regional trains. Urban rolling stock refers mainly to metros and trams. Regarding the existence of competitors, the Commission's preliminary finding showed that potential competitors, especially Chinese ones, were unlikely to enter these markets in the EU in the foreseeable future (European Commission 2018). From late 2018 to early 2019, Siemens proposed remedies to address these concerns but failed to win the Commission's approval. In the investigation process, the Commission consulted with the national competition authorities. Belgian, Dutch, German, Spanish, and UK competition authorities agreed with the Commission that the merger would seriously impede competition in the markets concerned (Barker 2019).

The European Commission's in-depth investigation prompted discussions on reforming European industrial policies. At the sixth ministerial meeting of the Friends of Industry in Paris on 18 December 2018, 18 member states, including France and Germany, announced a joint statement that said they would propose a new European industrial strategy to the next European Commission after the May 2019 European Parliament elections. ${ }^{3}$ These states argued that the EU 'must build a European industrial policy that encourages the creation of major economic players capable of facing global competition on equal terms'. Regarding competition matters, the joint statement called for the reform of EU competition law 'to better take into account international markets and competition' in merger reviews. It is considerably unusual for numerous member states to make such a proposal. However, this joint statement had little direct effect on the Commission's assessment of the Siemens/Alstom case.

It had become increasingly clear by December 2018 that the merger was going to be disapproved. The disagreement between the European Commission and the French and German governments remained unresolved. In a break with convention, the College of Commissioners met in mid-January 2019 to discuss this issue, although the investigation was ongoing (Barker 2019). This unusual decision-making process showed the political significance of the Siemens/Alstom case. Meanwhile, the French Minister of Economy and Finance, Bruno Le Maire, criticised the European Commission's position on various occasions between late 2018 and early 2019. He commented, 'if we want to be able to face competition with Chinese giants, we have to bring European forces together', and that applying the EU's 'obsolete' competition law to prohibit the Siemens/Alstom merger would be 'an economic error' and 'a political mistake' (Barker 2019; EURACTIV 2018, 2019a). The German government took a similar position. 
The German Federal Minister for Economic Affairs and Energy, Pater Altmaier, presented a 'National Industrial Strategy for 2030' on 5 February 2019, which was just one day before the Commission made the final decision on the Siemens/ Alstom case. The strategy focused on industrial policy issues such as support for small and medium-sized enterprises, investment in artificial intelligence, and protection of key technologies from foreign takeovers. He took this opportunity to state that EU merger rules should be reformed to allow the emergence of leading EU firms that are sufficiently large to compete with their Chinese and US competitors (EURACTIV 2019b).

On the same day, the President of the European Commission, Jean-Claude Juncker, delivered a keynote speech at the EU Industry Days event and stressed the importance of EU merger rules. Considering the timing of the speech, it is reasonable to assume that Juncker had the Siemens/Alstom controversy in mind. EURACTIV (2019a) reported that his speech prepared the ground for the disallowance of the Alstom/Siemens merger. He made two remarks concerning competition rules. First, he argued that EU merger control does not necessarily impede industrial development and that the European Commission approves most notifications with or without conditions. Between 1990 and 2019, the Commission approved more than 6,000 deals and blocked less than 30 . He said that 'this is a message for those who are saying that the Commission is composed of blind, stupid, stubborn technocrats' (Juncker 2019). Furthermore, he commented, 'we believe in competition - as long as it is fair for all. We will never play politics or play favourites when it comes to ensuring a level playing field'. Thus, President Juncker indicated that the European Commission would make independent decisions on merger cases despite mounting political pressure from certain member states.

On 6 February 2019, the European Commission decided to block the merger of Siemens and Alstom. ${ }^{4}$ European Competition Commissioner Vestegar remarked as follows:

Without sufficient remedies, this merger would have resulted in higher prices for the signalling systems that keep passengers safe and for the next generations of very high-speed trains. The Commission prohibited the merger because the companies were not willing to address our serious competition concerns.

(European Commission 2019)

Specifically, the Commission made the following argument in its decision (European Commission 2019). First, the proposed merger would remove a major competitor from the market of mainline and urban signalling systems in the EU market. Second, the merger would also remove one of the two largest manufacturers of considerably high-speed trains in the EU market. Third, the entrance of Chinese suppliers to these markets was unlikely because entrance barriers were high. Regarding signalling systems, Chinese manufacturers were not present in the EU market and had not even tried to participate in any tender. Their 
entrance to the considerably high-speed trains market was also unlikely because the experience of winning previous tenders was important in this area. Finally, while Siemens and Alstom proposed remedies, they did not fully address the competition concerns. While the European Commission generally prefers structural divestitures to other types of remedies, the firms took a different approach. For example, they offered to divest a train in capable of running at extremely high speeds (Alstom's Pendolino) or sell a license for Seimens' Velaro very highspeed technology, but the license was subject to multiple restrictive terms.

The French Minister of Economy and Finance, Bruno Le Maire, criticised the European Commission's decision and called it 'a political mistake'. He added that the European Commission's role is to defend the economic interests of Europe, but the Commission's decision to block the merger would serve China's economic and industrial interests (EURACTIV 2019c). Nevertheless, it is apparent that he failed to influence the Commission's decision on this case. An article by the Financial Times reported that the failure of the Alstom/Siemens merger showed the 'limits of political brute force' exercised by the German and French governments (Toplensky, McGee, and Keohane 2019). In addition, the article argued that the failure of the merger was partly attributable to the two firms' poor negotiation strategies, especially the reluctance of Siemens during the negotiations to make more substantial concessions, such as asset sales. Further, notably, within the EU, there was significant opposition to the merger from several member state governments, such as Denmark, Spain, and the United Kingdom, as well as several national competition authorities (Ewing 2019).

The European Commission's prohibition of the merger prompted a quick move by the French and German governments to propose major reforms in the EU's competition rules (EURACTIV 2019d). At a joint press conference in Berlin on 19 February 2019, the two governments published a policy document entitled 'A Franco-German Manifesto for a European Industrial policy fit for the 21st Century'. It proposed reforms on EU competition policy in the wider context of economic governance. The manifesto consists of three parts: 'Massively investing in innovation', 'Adapt our regulatory framework', and 'Effective measures to protect ourselves'. The second part is dedicated to competition policy issues. The part states the following:

Competition rules are essential but existing rules need to be revised to be able to adequately take into account industrial policy considerations in order to enable European companies to successfully compete on the world stage. Today, amongst the top 40 biggest companies in the world, only 5 are European. ${ }^{5}$

Based on this assessment of the current situation, the manifesto suggested considering five options, including the following three ideas about merger control ${ }^{6}$ :

1. Taking into greater consideration the state-control of and subsidies for undertakings within the framework of merger control 
2. Updating current merger guidelines to take greater account of competition at the global level, potential future competition, and the time frame when it comes to looking ahead to the development of competition to give the European Commission more flexibility when assessing relevant markets

3. Consider whether a right of appeal of the EU Council which could ultimately override European Commission decisions could be appropriate in well-defined cases, subject to strict conditions

The third point about the idea of giving veto power to the EU Council was particularly controversial. Germany and France abandoned it later because they faced strong opposition from other stakeholders (Oster 2020). Not surprisingly, DG Competition has reiterated that the independence of a supranational authority is essential for the maintenance of a level-playing field in the EU market. Similarly, French and German competition authorities disagree with the argument that EU competition rules are outdated and require substantial change. A group of smaller member states (the Czech Republic, Estonia, Finland, Ireland, Latvia, Lithuania, and the Netherlands) also take the view that EU competition policy should not be politicised. They seem to be afraid that larger member states may prioritise their interests if intergovernmental bodies gain more power in the competition decision-making process. Furthermore, the European Round Table for Industry - an association of the heads of large European firms-has expressed concerns about political interference in competition cases. It remains to be seen whether the EU's merger rules, most notably Regulation 139/2004, will be substantially changed based on the Franco-German manifesto.

Alstom changed its business strategy after the merger with Siemens was blocked. One year after the European Commission's decision, Alstom achieved a merger with a different partner, Bombardier Transportation, headquartered in Germany (European Commission 2020). Bombardier Transportation is a rail division of Bombardier, a diversified industrial group based in Canada. Alstom notified the Commission of the acquisition of Bombardier Transportation on 11 June 2020. After the merging parties proposed various remedies to address competition concerns, the Commission approved the merger on 31 July $2020 .^{7}$

The Siemens/Alstom case provides three insights into EU merger control. First, this case exhibited once again the European Commission's enormous regulatory influence on firms. Alstom abandoned the merger with Siemens and made substantial concessions in the merger with Bombardier Transportation to win the Commission's approval. Second, as with the Volvo/Scania case, the Commission resisted political pressure from member states. Even two of the largest member states, France and Germany, failed to change the Commission's position on this case. Third, although Siemens and Alstom stressed that their merger would lead to the creation of a European champion with greater international competitiveness, they failed to convince the Commission that this merit overweighs the merger's negative impact on market competition. This stance strongly suggests that the Commission's merger reviews are almost exclusively 
based on the competition criteria. The Commission pursues stringent competition regulations and does not aim to foster larger EU firms at the expense of effective competition in the EU market.

\subsubsection{E.ON/Endesa: the politics of foreign takeovers}

As the Volvo/Scania and Siemens/Alstom cases show, conflicts between national and supranational merger policies usually occur when the European Commission prohibits mergers, but their conflicts may also be caused by the Commission's approval of mergers. The latter possibility was illustrated by the E.ON/Endesa case and subsequent court battles between the Commission and Spain in the late 2000s. E.ON (Germany) and Endesa (Spain) are gigantic firms operating in the gas and electricity markets. To fully evaluate this long and complex case, it is necessary to put it in context. Two issues are noteworthy. The first issue is the process of European energy market liberalisation at the time and its relation to the EU's competition policy. The second issue is the controversy over the merger between the German firms E.ON and Ruhrgas. This case is important because it sets the scene for the E.ON/Endesa case. Both cases concerned the gas and electricity markets.

The 1990s and 2000s witnessed the gradual liberalisation of European energy markets. The EU used sectoral legislation and competition policy in combination to promote the liberalisation of this politically sensitive sector (Eberlein 2008; Green 2009). The EU spent nearly a decade on adopting the first set of rules concerning the liberalisation of the electricity and gas markets (Directives 96/92/EC and 98/30/EC). These directives were passed in 1996 and 1998, respectively, and they required a certain degree of liberalisation of the electricity and gas sectors. The second package of rules obliged member states to complete liberalisation by 2007 (Directives 2003/54/EC and 2003/55/EC). The second package also concerned the unbundling of power generation and supply networks in terms of management, whereas the third legislative package of 2009 required member states to ensure separation in terms of ownership (Directives 2009/72/EC and 2009/73/EC).

As the liberalisation of European energy markets progressed, the European Commission started to use its competition policy as one of the main instruments for regulating this sector. There are three main reasons for this change. First, while energy market liberalisation stimulated international business activities, some incumbents singed long-term contracts that foreclosed entry to the market (Green 2009: 294-296). Consequently, the Commission used competition rules to deal with these practices. Second, former state-owned energy firms tended to retain dominant market positions and close ties with their governments, as in the case of other network industries. Therefore, the Commission attempted to prevent abuse of dominant market positions. Third, some member states, such as Spain and France, attempted to block the acquisition of domestic energy firms by competitors from other member states. Spain attempted to hinder the acquisition 
of Endesa by Germany's E.ON, and France facilitated a merger between French firms Suez and Gaz de France to pre-empt a bid for Suez by Italy's Enel (Jacoby 2006). The Commission committed itself to tackling this issue because such intervention by national governments would hinder the creation of a single European energy market and potentially challenge the EU's jurisdiction over cross-border merger cases.

Neelie Kroes, who served as the European Commissioner for Competition between 2004 and 2010, prioritised the vigorous application of EU competition law in the energy sector. In her speech in June 2006, Commissioner Kroes (2006a) criticised certain member states' attempts to hinder cross-border mergers in the newly liberalised energy and financial sectors. She did not mention the names of these cases in her speech, but it was apparent that one of the cases she referred to was Spain's intervention in E.ON/Endesa. In September, she directly accused Spain of hindering the merger (Kroes 2006b). Under her leadership, the European Commission launched an in-depth investigation into this sector and published a report in 2007 (European Commission 2007). The report pointed out that the European gas and electricity markets were still highly concentrated and vertically and geographically fragmented despite the adoption of directives for liberalisation. Based on this finding, the Commission put more effort into tackling the anticompetitive practices of firms and governments in the energy sector.

An important merger case in the energy sector is E.ON/Ruhrgas, which set the scene for E.ON/Endesa and caused conflict between Spain and the European Commission. In August 2001, E.ON notified the German Federal Cartel Office (Bundeskartellamt) of its plan to acquire Gelsenberg and Bergemann, who held a large majority of shares in Ruhrgas. ${ }^{8}$ The Federal Cartel Office prohibited the acquisition of Gelsenberg and Bergemann in January and February 2002, respectively, arguing that the merger would strengthen dominant positions in the German gas and electricity markets (Bundeskartellamt 2002a, 2002b). In response, E.ON asked for ministerial approval by the Federal Ministry of Economy and Technology, which has the power to overturn the competition authority's decisions. E.ON stressed the merits of this merger, such as increased security of energy supply, greater international competitiveness, more employment, and greater capacity to achieve environmental policy goals (Henriksson 2005: 23). A non-binding evaluation by the Monopoly Commission of Germany supported the Federal Cartel Office's decisions and rejected all the reasons provided by E.ON. However, the ministry overturned the Federal Cartel Office's prohibition decisions and approved the merger on the ground of international competitiveness and energy security (Henriksson 2005: 23-24). Subsequently, several competitors of E.ON appealed to the Düsseldorf Higher Regional Court, and the court annulled the ministerial approval of the merger because of procedural problems. The ministry later provided a second authorisation of the merger.

E.ON/Ruhrgas has two important implications for national and supranational competition policies in Europe. First, this case showed that even Germany, one of the main advocates of competition law in the EU, could pursue industrial 
policy goals at the expense of strict merger control. Second, the case illustrated the limits of the EU's jurisdiction in merger cases. E.ON/Ruhrgas was considerably important for the future of the European energy market, but the Commission could not intervene in this case because of lack of jurisdiction. Article 1 of Regulation 139/2004 sets the turnover thresholds to define the scope of EU merger control (see Chapter 2). E.ON/Ruhrgas clearly reached these thresholds. However, the EU could not exercise jurisdiction over this case because both firms achieved more than two-thirds of their EU-wide turnover 'within one and the same' member state (the 'two-thirds rule'). In this respect, E.ON's acquisition of a British energy firm, Powergen, is noteworthy. E.ON announced this transaction in April 2001 and completed it in July 2002. If E.ON had completed its acquisition of Powergen faster, the Commission could have dealt with the E.ON/Ruhrgas case (Green 2009: 298).

While E.ON/Ruhrgas was exclusively handled by the German government, E.ON/Endesa reached the turnover thresholds for EU merger control. Therefore, the Commission exercised jurisdiction over the latter. In the mid-2000s, both E.ON and Endesa were active in the energy market, but they significantly differed from each other in terms of geographic markets (European Commission 2006a). E.ON was active in the generation, transmission, and supply of electricity and gas in many European countries. After the acquisition of Ruhrgas, E.ON had a considerably strong position in the German market, but it did not operate in Endesa's home market of Spain. Endesa mainly provided electricity in Europe and South America. In Spain, Endesa was active in the gas market. On 21 February 2006, E.ON announced a public bid to acquire the entire share capital of Endesa. The Spanish government favoured a bid by a leading Spanish gas supplier, Gas Natural, most likely because a merger between Endesa and Gas Natural would have led to the creation of a national energy champion (Chassany, Johnson, and Kahn 2006; EURACTIV 2006). However, E.ON made a bid of 29 billion euros for the deal and outbid Gas Natural. On 16 March 2006, E.ON notified the European Commission of the plan to acquire sole control of Endesa.

The European Commission approved the merger on 25 April without any conditions. ${ }^{9}$ The approval was based on four key findings (European Commission 2006a). First, E.ON and Endesa only had limited overlapping activities in the electricity markets in France, Italy, Germany, and Poland. Moreover, E.ON was not active in Spain, where Endesa was one of the two main suppliers of electricity. Regarding natural gas, the merging firms had no overlapping activities in national markets. Second, based on the initial investigation, the Commission found that E.ON could not be regarded as a likely entrant to the Spanish gas and electricity markets. Therefore, the Commission argued that the merger would not lead to the elimination of potential competition. Third, there was no clear evidence that the merger would significantly strengthen Endesa's position in the Spanish electricity market. Finally, the merger was unlikely to strengthen their purchasing power regarding gas procurement because E.ON and Endesa significantly differed from each other in terms of suppliers. While E.ON purchased 
natural gas from Russia, Norway, the Netherlands, Germany, the United Kingdom, and Denmark, Endesa imported it from Spain, Algeria, Nigeria, and Qatar. Based on these findings, the Commission concluded that the proposed merger would not significantly impede effective competition in the EU market or any substantial part of it.

Spain took a completely different position on the case. Only three days after the announcement of E.ON's bid for Endesa, the Spanish government enacted Royal Decree-Law 4/2006. This law gave more power to the Spanish National Energy Commission, Comisión Nacional de Energía (CNE), to regulate acquisitions in the energy sector (European Commission 2006b). The legislation required the CNE's authorisation for the acquisition of more than $10 \%$ of share capital, or any other percentage giving significant influence, in firms that engage in regulated activities or activities subject to special administrative control. Soon after the European Commission approved E.ON's merger plan, the CNE imposed nineteen conditions on it, ${ }^{10}$ exercising the new powers granted by the Royal DecreeLaw. Most importantly, E.ON was obliged to maintain Endesa and companies in its group for ten years, keeping Endesa's registered office and board of directors in Spain. The conditions also included the divestiture of some of Endesa's assets, such as nuclear power plants. It is widely believed that this intervention was based on economic nationalism because the CNE did not impose such conditions on the Spanish firm Gas Natural. Before E.ON launched the bid for Endesa, the CNE approved a similar bid by Gas Natural without any substantial restrictions (Cini and McGowan 2009: 152).

The European Commission took legal action against Spain regarding the violation of the EU's internal market and competition rules. On 3 May 2006, the European Commission requested the Spanish government to provide information about the Royal Decree-Law (European Commission 2006b). The Commission was concerned that the law may 'unduly restrict' the free movement of capital and the freedom of establishment under Articles 56 and 43 of the EC Treaty. Specifically, the legislation provided the reasons for which the CNE could refuse acquisitions. The reasons include the protection of the general interest and public security. According to the Commission, these concepts were vague and indeterminate and, consequently, granted too much discretion to the CNE (European Commission 2006b). On 26 September 2006, the Commission requested the Spanish government to modify the legislation, arguing that its authorisation procedure 'goes beyond what is necessary to safeguard the minimum supply of essential energy products and services and may deter investment from other Member States' (European Commission 2006c). On the same day, the Commission made a legally binding decision against the Spanish government. ${ }^{11}$ The decision drew two main conclusions (paragraph 132). First, the CNE's decision was illegal because it was adopted 'without communication to, or approval by, the commission' (European Commission 2006d). In other words, the CNE violated the prior notification procedure codified in Article 21 of Regulation 139/2004 (see Box 3.1). Second, the CNE's imposition of conditions 


\section{BOX 3.1 THE EU'S EXCLUSIVE COMPETENCE IN LARGE CROSS-BORDER MERGERS}

The EU's merger legislation, Regulation 139/2004, is based on the one-stop shop principle. To avoid conflicts between national and supranational competition authorities, Article 1 of the Regulation sets turnover thresholds for EU merger control. Mergers which reach these thresholds are considered to have the 'EU dimension' (see Box. 2.1). Furthermore, Article 21 defines the EU's jurisdiction in the regulation of mergers with the EU dimension (Harker 2007: 504-509). Paragraph 2 of the article states that 'the Commission shall have sole jurisdiction to take the decisions provided for in this Regulation'. Furthermore, paragraph 3 states that no member state shall apply its national competition law to any merger with the EU dimension, unless the European Commission voluntarily refers the case to a member state under Article 9 ('the exclusivity principle'). Notwithstanding these rules, member states may take 'appropriate measures to protect legitimate interests' under paragraph 4. Public security, plurality of the media, and prudential rules are regarded as legitimate interests. When member states take measures based on any other public interest, they must be communicated to, and approved by, the European Commission prior to their implementation.

on the E.ON/Endesa merger violated EU law on the free movement of capital and the freedom of establishment and 'unduly interfered with the Commission's exclusive competence' under Article 21 to regulate mergers with a 'Community dimension' (now 'Union dimension'). European Competition Commissioner Neelie Kroes told the press that the Commission 'will uphold the right to apply the EU's merger control rules' (European Commission 2006d). Her comment showed the Commission's determination to stop Spain's intervention.

However, the Spanish government neither revoked its measures nor provided a reason that could convince the European Commission of their necessity and legality. Therefore, the European Commission launched an infringement procedure under EU law against Spain on 18 October 2006 (European Commission 2006e). On 3 November, the Spanish Minister of Industry, Tourism and Trade imposed modified conditions on E.ON. Consequently, on 20 December, the European Commission once again made a legally binding decision that Spain violated EU law concerning the internal market and competition policy. ${ }^{12}$ The decision required Spain to withdraw the illegal conditions by 19 January 2007. Commissioner Kroes showed her determination to tackle this issue by saying that '[n]o one should doubt the commission's commitment to ensuring Europe's businesses can operate on a level playing field' (European Commission 2006f). Later, the Commission referred the matter to the Court of Justice. The court's 
judgement of 6 March 2008 declared that Spain failed to fulfil its obligations under the Commission's decisions. ${ }^{13}$ However, the proposed merger was later abandoned. In the face of a sudden rival bid, E.ON withdrew its merger notification during the court battle between the European Commission and Spain. In March 2007, Enel (Italy) and Acciona (Spain) launched a joint bid for Endesa. In April, Enel and Acciona agreed to transfer several rights and assets from Endesa to E.ON, and E.ON announced that it would no longer pursue sole control of Endesa. The Commission approved the joint acquisition of Endesa by Enel and Acciona in July. ${ }^{14}$

There are two interpretations of the Endesa saga: one underlines the European Commission's power to constrain the merger policies of national governments. Cini and McGowan (2009: 153) argue that the E.ON/Endesa case serves as 'a major warning to any other EU member state which might be tempted to prevent flagship companies from falling into foreign hands'. Another interpretation stresses that E.ON abandoned its pursuit of sole control of Endesa because of the Spanish government's intervention. Harker (2007: 518) argues that 'while the Commission has the formal powers to order the suspension of national measures likely to frustrate a transborder merger, in reality Member States have the ability to modify and even frustrate such a merger'. While these interpretations draw different conclusions, both highlight the profound disagreement between Spain and the European Commission.

The E.ON/Endesa case and the ensuing conflict clarified the European Commission's position on merger control. EU merger control is strict, but this does not necessarily mean that the Commission is more hostile to mergers than member states. Conversely, the Commission generally encourages cross-border mergers that do not significantly impede competition in the EU market (Kroes 2006a, 2006b). That is why the Commission confronts member states when they try to hinder the acquisition of firms by rivals based in other member states. Such attempts by national governments often involve discrimination against foreign firms and the application of non-competition criteria to merger cases. This implies that EU merger control has two key characteristics of a stringent competition policy: use of competition criteria and non-discrimination based on nationality.

This section carried out three case studies to examine whether EU merger control has the characteristics of stringent competition policy as opposed to strategic competition policy. If the creation of larger EU firms was a policy priority, the European Commission would have approved the proposed Volvo/Scania and Siemens/Alstom mergers. However, the Commission blocked both, defining relevant geographic markets rather narrowly and rejecting the international competitiveness defence. This finding provides evidence that the Commission pursues a stringent competition policy that prioritises the maintenance of market competition rather than the creation of larger EU firms. This does not necessarily mean that the Commission is more hostile than member states to all types of mergers. As the E.ON/Endesa case illustrates, the Commission generally 
promotes cross-border mergers, which is why the Commission confronts member states that try to protect their large domestic firms from foreign capital. This finding confirms that EU merger regulation aims to ensure non-discrimination, a key element of strategic competition policy.

\subsection{State aid control in times of economic crisis}

The EU's state aid control during and after the global financial crisis of 20072008 provides another good test of whether the EU pursues a stringent competition policy. There are two reasons why this case has been selected. First, state aid control is politically sensitive because it involves direct supranational actions against national governments and significantly constrains their economic policies, such as industrial policies. Such political sensitivity is evident in the fact that the EU's state aid control developed slowly and incrementally, as explained in Chapter 2. Therefore, it is worth examining whether the EU, especially the European Commission, adopts a stringent state aid policy, even if it risks a political backlash by EU member states. Second, it is widely recognised that economic crises pose a serious challenge to state aid control because governments tend to provide firms and other undertakings with massive state aid, such as subsidies, loans, and tax benefits, when their economies are in recession. Thus, the case of the global financial crisis that severely impacted the EU's economy helps to ascertain how resilient (or vulnerable) EU state aid control is to changes in macroeconomic conditions and prevailing politics.

As noted in Chapter 2, the main legal basis for EU state aid control is Articles 107-109 of the TFEU (formerly Articles 87-89 of the EC Treaty). Regarding these articles, there are two key points relevant to the following empirical analysis. First, in principle, EU member states must notify the European Commission of their state aid plans under Article 108(3) of the TFEU and obtain approval before implementing them, unless they are exempted from the EU's state aid rules. Second, Article 107 of the TFEU is particularly relevant to state aid control in the context of economic crises. On the one hand, the first paragraph of the article states that any aid granted by an EU member state that affects trade between EU member states and distorts market competition in the EU market shall be illegal. On the other hand, various exceptions to this general rule are listed in the second and third paragraphs of the article. Article 107(3)(b) states that state aid that is intended to 'remedy a serious disturbance in the economy of a Member State' may be permitted under EU law. This provision allows a degree of flexibility in the enforcement of EU state aid rules.

The outbreak of the global financial crisis between 2007 and 2008 caused serious and lasting damage to the European financial sector. Numerous European banks and other financial institutions were on the brink of bankruptcy and urgently needed financial assistance by EU member states (Doleys 2012: 554). For example, in late 2007 and early 2008, Northern Rock (United Kingdom), Roskilde (Denmark), and WestLB (Germany) were bailed out by 
governments. The crisis escalated in September 2008 because investment bank Lehman Brothers filed for bankruptcy protection in the United States. In the same month, the Belgian and Dutch governments rescued Fortis and Dexia, and this showed the real impact of the financial crisis on major European financial institutions. The total amount of state aid by EU member states sharply increased between 2008 and 2009. While the amount accounted for $0.54 \%$ of the total gross domestic products of the member states in 2007, it soared to $2.51 \%$ in 2008 and 3.62\% in 2009 (European Commission 2011a: 20).

This series of events had two significant implications for EU state aid control. First, the European Commission received a flood of state aid notifications by EU member states within a strict time frame. The European Commission had to find a way to cope with this unprecedented level of administrative overload. Second, uncoordinated government responses to domestic financial problems began to have negative external effects on other countries, such as capital outflows from their markets (Doleys 2012: 554-555). In order to address this problem, the finance ministers of EU member states met at the meeting of the EU Council ('Ecofin Council') on 7 October 2008 and collectively called on the European Commission to clarify how it intended to apply EU state aid rules to the financial sector (EU Council 2008: 3).

Against this background, the European Commission issued four temporary communications between 2008 and 2009 to provide EU member states with guidelines on its state aid control in the face of the global financial crisis. On 25 October 2008, the Commission adopted the 'banking communication', which was concerned with the application of state aid rules to measures taken in relation to financial institutions in the context of the crisis (European Commission 2008). While state aid to firms in difficulties are normally assessed under Article 87(3)(c) of the EC Treaty, this communication clearly stated that the treaty provision on economic crises would be applicable to crisis-related state aid to financial institutions:

In the light of the level of seriousness that the current crisis in the financial markets has reached and of its possible impact on the overall economy of Member States, the Commission considers that Article 87(3)(b) is, in the present circumstances, available as a legal basis for aid measures undertaken to address this systemic crisis.

(European Commission 2008, paragraph 9)

At the same time, the communication stressed that Article 87(3)(b) could be invoked 'only in genuinely exceptional circumstances where the entire functioning of financial markets is jeopardised' (paragraph 11). Subsequently, to provide additional guidelines, the European Commission adopted three communications that were concerned with the recapitalisation of financial institutions, the treatment of impaired assets in the banking sector, and the assessment of restructuring measures, respectively (European Commission 2009a, 2009b, 2009c). In these 
documents, the European Commission explained what EU member states could do under existing state aid rules and clarified conditions that must be met before invoking Article 87(3)(b). In these ways, the Commission facilitated the rescue of financial institutions by EU member states.

The financial crisis impacted not only the financial sector, but also the real economy. Therefore, the European Commission amended its state aid rules to ensure that they would not obstruct EU member states' timely provision of state aid to non-financial firms. On 22 January 2009, the Commission adopted a temporary framework under Article 87(3)(b) of the treaty to allow the speedy granting of a limited amount of aid to firms and other undertakings severely impacted by the global financial crisis (European Commission 2009d). This framework applied from 17 December 2008 to 31 December 2010 and temporarily permitted EU member states to provide state aid that did not exceed a cash grant of 500,000 euros per undertaking without obtaining approval from the European Commission in advance. As the exemption threshold was 200,000 euros before the crisis, the framework gave more discretion to member state governments to grant state aid to firms in difficulties. After the expiry of this temporary framework, a similar communication was adopted by the European Commission in January 2011 and applied until December 2011 (European Commission 2011b).

During the crisis, the Competition Commissioner, Neelie Kroes, played a key practical and discursive role in the maintenance of supranational state aid control (Cini 2014: 32-34). Regarding policy practices, the Commission issued the above-mentioned communications during her term. Regarding policy discourse, she resisted mounting pressure from member states to relax EU competition policy and consistently insisted that they must comply with EU state aid rules to avoid the serious distortion of market competition. Referring to past economic crises such as the Great Depression, she stressed the danger of protectionism and the importance of maintaining competition even in a time of crisis (Kroes 2009).

Overall, the case of the global financial crisis showed the resilience of the EU's supranational state aid control. There are three key pieces of evidence of this point. First, concerning the real economy, the relaxation of EU state aid rules was temporary. As noted above, the temporary framework of 2009 was prolonged by one year, but there was no additional extension. Second, the EU's regulation of state aid to financial institutions followed a similar pattern. In the early phase of the financial crisis, the Commission temporarily authorised all crisis-related state aid to financial institutions, deviating from its own 2004 Rescue and Restructuring Guidelines. However, in the above-mentioned communication of July 2009 on the assessment of restructuring measures, the European Commission required banks and other financial institutions to submit restructuring plans in exchange for the temporary authorisation of crisis-related state aid. By obliging beneficiaries of emergency state aid to implement their restructuring plans (e.g. the divestment of non-core assets), the European Commission ensured that competition in the EU financial sector would not be distorted significantly in the long run (Botta 2016: 272-274; Doleys 2012: 561-562). Third, 
the European Commission's competence on state aid control was preserved, despite mounting pressure from member states. At a European Council meeting in September 2008, French President Nicolas Sarkozy proposed the exemption of crisis-related aids to financial institutions from EU state aid rules (Botta 2016: 269). Such exemption could have considerably undermined the European Commission's decision-making power. However, this French initiative failed because most member states increasingly recognised that uncoordinated national measures to rescue their own financial institutions could trigger a 'subsidy war' and jeopardise a speedy economic recovery of the EU economy (Botta 2016: 269). As the proposed decision under Article 82(2) of the EC Treaty required unanimity, France ultimately abandoned the idea.

While EU state aid control was largely passive during the global financial crisis, the European Commission gradually began to take a proactive state aid policy in the mid-2010s under the leadership of the Competition Commissioner Joaquín Almunia (2010-2014) and his successor, Margrethe Vestager (2014-present). In 2013, the Commission started to investigate the tax ruling practices of member states to address the issue of tax avoidance. While the EU member states retain their taxation competence, the Commission insisted that state aid rules apply to the favourable tax treatment of certain firms that distorts competition in the EU market. On 11 February 2014, Almunia delivered a speech at the European Competition Forum, a flagship event organised by DG Competition, and stressed the Commission's determination to tackle this salient issue in the context of state aid control. He emphasised the importance of fair taxation, referring to policy debates over corporate-tax regimes in the OECD and the Group of Twenty, which intensified after the global financial crisis (Almunia 2014).

Between 2015 and 2020, the European Commission adopted eight decisions on state aid cases concerning the tax ruling practices of EU member states, as shown in Table 3.1. In October 2015, the European Commission ordered the Governments of Luxembourg and the Netherlands to recover aid granted to Fiat (Italy) and Starbucks (United States), respectively. These were the first Commission decisions concerning tax rulings. While the amount of aid to be recovered was relatively small (23 and 26 million euros, respectively), these two cases set a precedence in this regulatory area. In January 2016, the Commission decided that Belgium's tax exemption scheme, which benefited 39 multinational companies, violated EU state aid law. In August 2016, the Commission ordered Ireland to recover 14.3 billion euros from Apple (United States). This case attracted widespread media coverage because of the record-breaking amount of aid to recover. Furthermore, between 2017 and 2018, the Commission adopted decisions on three cases and asked Luxembourg to recover approximately 1.3 billion euros in total from the beneficiaries-Amazon (United States), ENGIE (France), and McDonald's (United States). The United Kingdom did not comply with the Commission's decision of 2 April 2019 and withdrew from the EU without recovering its aid to certain multinational companies. The European Commission brought this case to the Court of Justice in March 2021. 
TABLE 3.1 The European Commission's state aid decisions concerning tax rulings as of 31 March 2021

\begin{tabular}{|c|c|c|c|}
\hline Member states involved & Case title & Decision date & Case number \\
\hline The United Kingdom & $\begin{array}{l}\text { UK tax scheme for } \\
\text { multinationals: controlled } \\
\text { foreign company rules }\end{array}$ & 02.04 .2019 & SA.44896 \\
\hline Luxembourg & Alleged aid to McDonald's & 19.09.2018 & SA.38945 \\
\hline Luxembourg & $\begin{array}{l}\text { State aid implemented by } \\
\text { Luxembourg in favour of } \\
\text { ENGIE }\end{array}$ & 20.06 .2018 & SA.44888 \\
\hline Luxembourg & $\begin{array}{l}\text { State aid granted by } \\
\text { Luxembourg to Amazon }\end{array}$ & 04.10 .2017 & SA.38944 \\
\hline Ireland & $\begin{array}{l}\text { State aid implemented by } \\
\text { Ireland to Apple }\end{array}$ & 30.08 .2016 & SA.38373 \\
\hline Belgium & $\begin{array}{l}\text { Excess profit exemption in } \\
\text { Belgium: Article } 185(2)(\mathrm{b})\end{array}$ & 11.01.2016 & SA.37667 \\
\hline The Netherlands & $\begin{array}{l}\text { State aid implemented by the } \\
\text { Netherlands to Starbucks }\end{array}$ & 21.10.2015 & SA.38374 \\
\hline Luxembourg & $\begin{array}{l}\text { State aid which Luxembourg } \\
\text { granted to Fiat }\end{array}$ & 21.10.2015 & SA.38375 \\
\hline
\end{tabular}

Source: Adapted from DG Competition website 'Tax rulings': https://ec.europa.eu/competition/ state_aid/tax_rulings/index_en.html, accessed 31 March 2021.

On the one hand, this assertive state aid policy of the European Commission has been questioned from numerous legal experts (Gormsen 2019). On the other hand, the policy has been partly challenged by the General Court of the EU. In the Fiat judgement of 24 September 2019, the General Court upheld the European Commission's decision against Luxembourg. ${ }^{15}$ Conversely, in the Starbucks judgement, the General Court annulled the Commission's decision against the Netherlands on the grounds that the decision did not show how tax rulings provided by the Netherlands disadvantaged competitors of Starbucks. ${ }^{16}$ Furthermore, in July 2020, the General Court overturned the Commission's decision regarding Ireland's tax rulings addressed to Apple, saying that the Commission failed to show why Ireland's practice had discriminatory effects. ${ }^{17}$ The Commission appealed the case to the Court of Justice of the EU (European Commission 2021). While this judgement is widely regarded as a major setback in the European Commission's stringent state aid control relating to taxation, it should also be noted that the court did not question the EU's competence in this area. The Commission continues investigating other cases related to tax rulings.

In summary, EU state aid control was temporarily relaxed during the global financial crisis, but its overall structure was largely preserved despite political pressure from member states such as France. Since the mid-2010s, the European Commission has adopted a strict state aid policy regarding the tax practices of member states. It seemed that the Commission would once again pursue a stringent state aid policy. However, the outbreak of the coronavirus pandemic prompted EU member states to grant massive state aid, posing a major challenge 
to EU state aid control (for more details, see Chapter 6). Overall, the evidence shows that, among the four main sub-fields of EU competition policy, state aid control is most sensitive to macroeconomic conditions and prevailing politics.

\section{Conclusion}

The disallowance of the proposed Volvo/Scania and Siemens/Alstom mergers in 2000 and 2019 suggests that the European Commission prioritises the maintenance of market competition rather than the creation of larger EU firms. The Commission tends to define geographic markets narrowly while adopting decisions based solely on the competition criteria. This does not necessarily mean that the Commission is more hostile than member states to all types of mergers. As the E.ON/Endesa case in 2006 and the subsequent court battle between the Commission and Spain illustrate, the Commission generally promotes cross-border mergers and confronts member states that try to protect their large domestic firms from foreign capital. The analysis of state aid control has offered more nuanced insights. After the global financial crisis of 2007-2008, EU state aid rules were temporarily relaxed. Subsequently, the Commission once again began to ensure strict law enforcement and tackled the issue of tax rulings. However, the ongoing outbreak of COVID-19 posed one of the biggest challenges to EU state aid control. Further research is necessary to thoroughly evaluate the impact of the economic crisis caused by the current ongoing pandemic.

\section{Notes}

1 Case COMP/M.1672, Volvo/Scania, Commission decision of 14 March 2000, OJ L143/74, 29 May 2001.

2 Case M.8677, Siemens/Alstom.

3 A joint statement by France, Austria, Croatia, Czech Republic, Estonia, Finland, Germany, Greece, Hungary, Italy, Latvia, Luxembourg, Malta, the Netherlands, Poland, Romania, Slovakia, and Spain [Online]. Available at: https://www.bmwi.de/ Redaktion/DE/Downloads/F/friends-of-industry-6th-ministerial-meetingdeclaration.pdf?__blob=publicationFile $\& v=6$ [accessed: 31 March 2021].

4 Case M.8677, Siemens/Alstom, Commission decision of 6 February 2019, C(2019)921 final.

5 A Franco-German Manifesto for a European industrial policy fit for the 21st Century [Online]. Available at: https://www.gouvernement.fr/sites/default/files/locale/ piece-jointe/2019/02/1043_-_a_franco-german_manifesto_for_a_european_ industrial_policy_fit_for_the_21st_century.pdf [accessed: 31 March 2021], p. 3.

6 Ibid., p. 4.

7 Case M.9779, Alstom/Bombardier Transportation, Commission decision of 31 July 2020, C(2020)5412 final.

8 Bundeskartellamt, Cases B8-109/01 and B8-149/01.

9 Case COMP/M.4110, E.ON/Endesa, OJ L114/4, 16 May 2006.

10 Case COM/M.4197, E.ON/Endesa, C(2006)4279 final, 26 September 2006, paragraph 18.

11 Case COM/M.4197, E.ON/Endesa, C(2006)4279 final, 26 September 2006.

12 Case COM/M.4197, E.ON/Endesa, C(2006)7039 final, 20 December 2006.

13 Court of Justice, Case C-196/07, Commission v. Spain, ECLI:EU:C:2008:146. 
14 Case COMP/M.4685, Enel/Acciona/Endesa, OJ C212/2, 11 September 2007.

15 Joined Cases T-775/15 and T-759/15, Grand Duchy of Luxembourg and Fiat Chrysler Fiance Europe v. European Commission, ECLI:EU:T:2019:670.

16 Joined Cases T-760/15 and T636/16, Kingdom of the Netherlands and Others v. European Commission, ECLI:EU:T:2019:669.

17 Joined Cases T-778/16 and T-892/16, Ireland and Others v European Commission, ECLI:EU:T:2020:338.

\section{References}

Almunia, J. (2014). Fighting for the Single Market. Speech at the European Competition Forum, Brussels, 11 February [Online]. Available at: https://ec.europa.eu/commission/ presscorner/detail/en/SPEECH_14_119 [accessed: 31 March 2021]

Barker, A. (2019). Regulator Raises Antitrust Doubts Over Siemens-Alstom Tie-up; Rail Merger. Financial Times (USA Edition). 14 January.

Botta, M. (2016). Competition Policy: Safeguarding the Commission's Competences in State Aid Control. Journal of European Integration, 38(3), pp. 265-278.

Bundeskartellamt (2002a). Bundeskartellamt Prohibits E.ON/Gelsenberg (Ruhrgas) Merger, Press Release, 21 January.

Bundeskartellamt (2002b). Bundeskartellamt Prohibits E.ON's Acquisition of Majority Stake in Ruhrgas, Press Release, 28 February.

Chassany, A. S., Johnson, K. and Kahn, G. (2006). France Moves to Block Italian Suitor for Suez. Wall Street Journal. 27 February.

Cini, M. (2014). Economic Crisis and the Internationalisation of EU Competition Policy. In: M. J. Rodrigues and E. Xiarchogiannopoulou (eds), The Eurozone Crisis and the Transformation of EU Governance. Surrey: Ashgate, pp. 29-39.

Cini, M. and McGowan, L. (2009). Competition Policy in the European Union, 2nd ed. Basingstoke: Palgrave Macmillan.

Doleys, T. (2012). Managing State Aid in a Time of Crisis: Commission Crisis Communications and the Financial Sector Bailout. Journal of European Integration, $34(6)$, pp. $549-565$.

Eberlein, B. (2008). The Making of the European Energy Market: The Interplay of Governance and Government. Journal of Public Policy, 28(1), pp. 73-92.

EU Council. (2008). Immediate Responses to Financial Turmoil: Council Conclusions: Ecofin Council of 7 October 2008, 13930/08, Presse 284.

EURACTIV. (2006). Spain Warned over Endesa Merger Blockage. 28 August.

EURACTIV. (2017). Alstom, Siemens Merge to Create New European Rail Champion. 27 September.

EURACTIV. (2018). 19 EU Countries Call for New Antitrust Rules to Create "European Champions". 19 December.

EURACTIV. (2019a). Juncker Prepares the Ground for Alstom-Siemens Merger Rejection. 5 February.

EURACTIV. (2019b). German 2030 Industrial Strategy: Altmaier Backs "European Champions". 7 February.

EURACTIV. (2019c). Six Takeaways from Siemens-Alstom Rejection. 7 February.

EURACTIV. (2019d). France, Germany Call for a Change of European Regulatory Rules. 20 February.

European Commission. (1999). Commission Opens In-depth Inquiry into Volvo/Scania Merger, Press Release, IP/99/793. 
European Commission. (2000a). The Commission Prohibits Volvo's Acquisition of its Main Competitor Scania, Press Release, IP/00/257.

European Commission. (2000b). Commission Clears Volvo's Acquisition of Renault's Truck Business Subject to Significant Undertakings, Press Release, IP/00/962.

European Commission. (2006a). Mergers: Commission Approves Acquisition by E.ON of Endesa, Press Release, IP/06/528.

European Commission. (2006b). Free Movement of Capital: Commission Opens Infringement Proceedings Against Spain Regarding Law Amending Functions of Spanish Electricity and Gas Regulator, Press Release, IP/06/569.

European Commission. (2006c). Free Movement of Capital: Commission Calls on Spain to Modify the Law Amending the Functions of the Spanish Electricity and Gas Regulator, Press Release, IP/06/1264.

European Commission. (2006d). Mergers: Commission Rules Against Spanish Energy Regulator's Measures Concerning E.ON's Bid for Endesa, Press Release, IP/06/1265.

European Commission. (2006e). Mergers: Commission Opens Infringement Procedure Against Spain for not Lifting Unlawful Conditions Imposed by CNE on E.ON's Bid for Endesa, Press Release, IP/06/1426.

European Commission. (2006f). Mergers: Commission Decides that Spanish Measures in Proposed E.ON/Endesa Takeover Violate EC Law, Press Release, IP/06/1853.

European Commission. (2007). Communication from the Commission: Inquiry Pursuant to Article 17 of Regulation (EC) No 1/2003 into the European Gas and Electricity Sectors (Final Report), COM(2006)851 final.

European Commission. (2008). Communication from the Commission: The Application of State Aid Rules to Measures Taken in Relation to Financial Institutions in the Context of the Current Global Financial Crisis, OJ C270/8, 25 October 2008.

European Commission. (2009a). Communication from the Commission: The Recapitalization of Financial Institutions in the Current Financial Crisis: limitation of the Aid to the Minimum Necessary and Safeguards against Undue Distortions of Competition, OJ C10/2, 15 January 2009.

European Commission. (2009b). Communication from the Commission on the Treatment of Impaired Assets in the Community Banking Sector, OJ C72/1, 26 March 2009.

European Commission (2009c). Commission Communication on the Return to Viability and the Assessment of Restructuring Measures in the Financial Sector in the Current Crisis under the State Aid Rules, OJ C195/9, 19 August 2009.

European Commission. (2009d). Temporary Community Framework for State Aid Measures to Support Access to Finance in the Current Financial and Economic Crisis, OJ C16/1, 22 January 2009.

European Commission. (2011a). Report on Competition Policy 2010, COM(2011)328 final.

European Commission. (2011b). Communication of the Commission: Temporary Union Framework for State Aid Measures to Support Access to Finance in the Current Financial and Economic Crisis, OJ C6/5, 11 January 2011.

European Commission. (2018). Mergers: Commission Opens In-depth Investigation into Siemens Proposed Acquisition of Alstom, Press Release, IP/18/4527.

European Commission. (2019). Mergers: Commission Prohibits Siemens' Proposed Acquisition of Alstom, Press Release, IP/19/881.

European Commission. (2020). Mergers: Commission Clears Alstom's Acquisition of Bombardier, Subject to Conditions, Press Release, IP/20/1437. 
European Commission. (2021) State Aid: Commission Refers United Kingdom to European Court for Failure to Fully Recover Illegal Tax Exemption Aid of up to Around $€ 100$ Million in Gibraltar, Press Release, IP/21/1266.

Ewing, J. (2019). E.U. Blocks Siemens-Alstom Plan to Create European Train Giant. New York Times. 6 February.

Gormsen, L. L. (2019). European State Aid and Tax Rulings. Cheltenham: Edward Elgar.

Green, R. (2009). European Union Regulation and Competition Policy Among the Energy Utilities. In: X. Vives (ed), Competition Policy in the EU: Fifty Years on from the Treaty of Rome. Oxford: Oxford University Press, pp. 284-313.

Harker, M. (2007). Cross-Border Mergers in the EU: The Commission V the Member States. European Competition Journal, 3(2), pp. 503-535.

Henriksson, E. (2005). Assessing the Competitive Effects of Convergence Mergers: The Case of the Gas-Electricity Industries. Licentiate Thesis, Luleå University of Technology.

Jacoby, M. (2006). EU's Kroes Rejects Talk of Protectionist Battle. Wall Street Journal. 30 March.

Juncker, J. C. (2019). Keynote Speech. Speech at the EU Industry Days 2019, Brussels, 5 February [Online]. Available at: https://ec.europa.eu/commission/presscorner/ detail/en/SPEECH_19_870 [accessed: 31 March 2021].

Kroes, N. (2006a). Challenges to the Integration of the European Market: Protectionism and Effective Competition Policy. Speech at the Institute of Electrical Engineers, London, 12 June [Online]. Available at: https://ec.europa.eu/commission/ presscorner/detail/en/SPEECH_06_369 [accessed: 31 March 2021].

Kroes, N. (2006b). Cross-border Mergers and Energy Markets. Speech at Villa d'Este Forum, Cernobbia, 2 September [Online]. Available at: https://ec.europa.eu/ commission/presscorner/detail/en/SPEECH_06_480 [accessed: 31 March 2021].

Kroes, N. (2009). Lessons Learned from the Economic Crisis. Speech at the European Parliament, Brussels, 29 September [Online]. Available at: https://ec.europa.eu/ commission/presscorner/detail/en/SPEECH_09_420 [accessed: 31 March 2021].

Latour, A. (1999). Volvo to Buy Majority Stake in Scania for $\$ 7.4$ Billion. Wall Street Journal. 6 August.

Miller, S. and Lindroth, J. (2000). Volvo-Scania Deal Appears Doomed: Latest Concession May Be Too Late. Wall Street Journal. 9 March.

Milner, M. (2000). Volvo Hardens its Stance on Bid for Rival Scania: Truck Maker at Impasse with EU Competition Body. Guardian. 9 March.

Mitchener, B. (2000). EU Commission Is Unmoved By Rare Plea From Stockholm. Wall Street Journal. 17 February.

Monti, M. (2001). Market Definition as a Cornerstone of EU Competition Policy. Speech at Helsinki Fair Centre, Helsinki, 5 October [Online]. Available at: https://ec.europa.eu/commission/presscorner/detail/en/SPEECH_01_439 [accessed: 31 March 2021].

Oster, T. (2020). European Industrial Policy vs. European Competition Law: State of Play 18 Months after the Siemens-Alstom Decision [Online]. Available at: https:// www.twobirds.com/en/news/articles/2020/global/european-industrial-policy-vseuropean-competition-law-state [accessed: 31 March 2021].

Siemens and Alstom (2017). Siemens and Alstom Join Forces to Create a European Champion in Mobility, Joint Press Release [Online]. Available at: https://assets.new. siemens.com/siemens/assets/api/uuid:a4c5055b-1954-4eda-80f0-501904dd73ea/ pr2017090442coen.pdf [accessed: 31 March 2021]. 
Thatcher, M. (2014). European Commission Merger Control: Combining Competition and the Creation of Larger European Firms. European Journal of Political Research, 53(3), pp. 443-464.

Toplensky, R., McGee, P. and Keohane, D. (2019). Death of Planned Alstom-Siemens Merger Shows Limits of Political Brute Force; Antitrust decision. Financial Times (USA Edition). 8 February.

Winestock, G. (2000). European Commission Bars Volvo, Scania From Merging. Wall Street Journal. 15 March. 


\section{4}

\section{THE ISSUE OF DISCRIMINATION AGAINST NON-EU FIRMS}

The issue of nationality-based discrimination is seldom discussed in the political science literature on EU competition policy, although it is a crucial issue, especially for non-EU firms. To fill this gap in the literature, this chapter empirically ascertains whether EU competition policy discriminates against non-EU firms. This chapter has three sections: cartels, abuse of dominance, and mergers. Each section consists of two parts: an analysis of the European Commission's overall law enforcement records and case studies. The former aims to provide a global picture of EU competition policy, mainly from the 1990s to the 2010s, and the latter examines high-profile cases involving non-EU firms. The case studies will explain the context, trace the decision-making process, and discuss whether the cases provide any evidence of nationality-based discrimination. To make balanced arguments, this chapter will engage with discussions about EU competition policy in Japan and the United States. In terms of material, the chapter will draw on a wide range of sources, including the EU's statistics and publications, publications of the Japanese government and business associations, an interview with the Japanese delegation to the EU, speeches of senior US officials, and news articles published by European and non-European media. The empirical findings show that, while EU competition policy has many shortcomings, it is nondiscriminatory, as hypothesised in Chapter 1.

\subsection{Cartels}

A starting point for discussion is the observation that EU cartel control has significant external implications. Today, the EU often fines non-EU firms involved in international cartels. This development is attributable to three main factors. First, it responds to the increasing number of cross-border cartels. Second, the EU has gained the power to apply its cartel rules extraterritorially because of 
the development of legal doctrines explained in Chapter 2. Third, the European Commission's capacity to detect complex international cartels has significantly increased thanks to the introduction and revision of the leniency programme in the 1990s and the 2000s, as noted in Chapter 2. According to a report by the OECD (2014: 32-33), 35\% of EU cartel decisions during 1990-2000 involved non-EU firms, and the proportion increased to 58\% between January 2001 and July 2013.

This development of EU cartel control's external dimension may give the impression that the European Commission targets non-EU firms, but that is not necessarily the case. It may be the case that many of the EU's cartel decisions involve both EU and non-EU firms. In fact, among the 100 cartels fined by the Commission between January 1990 and July 2013, 47 involved both EU and non-EU firms. Only five cases involved exclusively non-EU firms (OECD 2014: 33). These figures indicate that the internationalisation of cartel policy and nationality-based discrimination are not synonymous, although they are often confused with each other. Against this background, this section examines the discrimination issue by focusing on two questions. The first question is whether non-EU firms are involved more frequently than EU firms in the Commission's cartel decisions. The second question is whether fines against non-EU firms are disproportionately heavier than fines against EU firms.

\subsubsection{The discrimination issue in terms of frequency and fines}

The Japanese government and European Commission have expressed their opinions on whether non-EU firms are more frequently involved than EU firms in EU cartel cases. The Japanese government's position on this issue was explained most explicitly by the Japanese Ministry of Economy, Trade and Industry (METI). In 2008, METI established the Study Group regarding Competition Law Compliance, consisting of competition law experts, to conduct research on the international aspects of competition law and policy. The establishment of this group reflected the Japanese business community's concerns about the international enforcement of competition rules by the EU and other countries, as explained in greater detail below. In 2010, the study group prepared a report for METI, and the report found no clear evidence of nationality-based discrimination by the European Commission in cartel control (METI 2010: 10). According to the report, the Commission fined 278 firms during 2003-2009, 217 of which were EU firms. The remaining 61 firms consisted of 23 American firms, 23 Japanese firms, 11 Swiss firms, and 4 from other countries. In other words, non-EU firms accounted for only $22 \%$ of the cartel participants. More recent data on this issue were provided by European Competition Commissioner Margrethe Vestager (2015a). According to her speech in 2015, 195 firms were involved in the commission's cartel decisions between 1 January 2010 and 18 June 2015. Among these firms, 120 (62\%) were based in the EU, and 75 (38\%) were from non-EU countries. These two pieces of information from Japanese and EU sources show no clear evidence of discrimination against non-EU firms. 
Regarding the issue of cartel fines, Cremieux and Snyder (2016) and the EU's official statistics are insightful. Cremieux and Snyder conducted a comparative statistical analysis of EU and US cartel control. They examined 627 fines imposed by the EU and 267 fines imposed by the United States during 1994-2014. Their research suggests that the EU imposes fines irrespective of the nationality of firms, whereas the United States imposes higher fines on foreign firms than US firms (Cremieux and Snyder 2016: 797). Similarly, the EU's official statistics suggest that cartel fines on non-EU firms are not necessarily higher than those on EU firms. Table 4.1 provides a list of the 10 highest cartel fines per firm as of 31 March 2021. The table shows that 8 out of 10 fines were imposed on firms based in EU member states (France, Germany, Italy, the Netherlands, and Sweden). The only non-EU firms in the list are F. Hoffmann-La Roche (hereinafter 'Roche') based in Switzerland and LG Electronics based in South Korea. This is in sharp contrast to US cartel control, which targets foreign firms. In the United States, the top-10 cartel fines as of February 2015 were against non-US firms and their subsidiaries in the United States, according to a report by METI (2015: 10). ${ }^{1}$ The two non-EU firms in Table 4.1, namely Roche and LG Electronics, were involved in the vitamins case and TV and computer monitor tubes case, respectively. As explained below, neither of them provides evidence of discrimination against non-EU firms.

The vitamin cartel case (2001) involved one of the most serious cartels the EU has ever detected (European Commission 2001a). The European Commission started an investigation into this case in May 1999. In November 2001, the Commission decided to fine eight firms a total of 855 million euros for participating in price-fixing and market-sharing cartels from 1989 to 1999, which affected the market for various vitamin products such as health supplements, animal feed, pharmaceutical products, and cosmetics. ${ }^{2}$ This series of cartels

TABLE 4.1 The EU's 10 highest cartel fines by firm as of March 2021

\begin{tabular}{lllc}
\hline Year & Firm & Case & Fine (€ million) \\
\hline 2016 & Daimler (Germany) & Trucks & 1,009 \\
2017 & Scania (Sweden) & Trucks & 881 \\
2016 & DAF (Netherlands) & Trucks & 753 \\
2008 & Saint Gobain (France) & Carglass & 715 \\
2012 & Philips (Netherlands) & TV and computer monitor tube & 705 \\
2012 & LG Electronics (South Korea) & TV and computer monitor tube & 688 \\
2016 & Volvo/Renault Trucks (Sweden) & Trucks & 670 \\
2016 & Iveco (Italy) & Trucks & 495 \\
2013 & Deutsche Bank (Germany) & Euro interest rate derivatives & 466 \\
2001 & F. Hoffmann-La Roche & Vitamins & 462 \\
& (Switzerland) & & \\
\hline
\end{tabular}

Source: Adapted from DG Competition website '1. Cartel Statistics', p. 3: https://ec.europa.eu/ competition/cartels/statistics/statistics.pdf, accessed 31 March 2021.

Note: The table shows fines after adjustments following judgements of the EU courts. 
TABLE 4.2 Fines imposed in the vitamins case (2001)

\begin{tabular}{lcc}
\hline Firm & $\begin{array}{c}\text { Reduction under the } \\
\text { leniency notice }\end{array}$ & Fine (€ million) \\
\hline F. Hoffmann-La Roche (Switzerland) & $50 \%$ & 462 \\
BASF (Germany) & $50 \%$ & 296 \\
Aventis (France) & $100 \%$ (Vitamins A and E) & 5 \\
Solvay Pharmaceuticals (Netherlands) & and 10\% (the others) & 9 \\
Merck (Germany) & $15 \%$ & 9 \\
Daiichi Pharmaceutical (Japan) & $35 \%$ & 23 \\
Eisai (Japan) & $35 \%$ & 13 \\
Takeda Chemical Industries (Japan) & $30 \%$ & 37 \\
\hline
\end{tabular}

Source: The European Commission decision of 21 November 2001, OJ L6/1, 10 January 2003, points 768 and 665 .

mainly operated in Europe, North America, and Japan. Then Competition Commissioner Monti commented that this was 'the most damaging series of cartels the Commission has ever investigated' (European Commission 2001a). Roche, the world's largest vitamin producer, played a central role in organising and monitoring this international cartel, while BASF (Germany) and Takeda Chemical Industries (Japan) played the role of junior coordinators. Table 4.2 shows the names of these cartel participants, locations of their headquarters, and fines imposed by the Commission. It is not surprising that the heaviest fine was imposed on Roche, the non-EU firm, because it played a leadership role in this cartel. The table also shows that the Commission imposed severe fines on four EU firms, especially BASF (Germany). Therefore, this case shows no clear evidence that the Commission imposes higher fines on non-EU firms.

The same can be said about the TV and computer monitor tubes case. The European Commission began an investigation into this case and conducted unannounced inspections in November 2007. The Commission fined seven international groups of companies a total of 1.47 billion euros in 2012. ${ }^{3}$ The case involved major European, Japanese, and Korean manufacturers of electronic equipment. They conducted various anticompetitive practices (price fixing, market sharing, and customer allocation) globally between 1996 and 2006 in the market for 'cathode ray tubes', which are used to produce TV and computer screens. It seems that firms tried to address the decline of the cathode ray tube market by restricting market competition. These were among the most organised cartels the Commission had ever detected, and the participants were well aware that they were breaking EU competition law. For example, one document recording the cartel stated that 'producers need to avoid price competition through controlling their production capacity', while another document urged, 'Please dispose the following document after reading it' (European Commission 2012). The then Vice President of the European Commission responsible for competition policy, Joaquín Almunia, called it a 'textbook' cartel, which 
TABLE 4.3 Fines imposed in the TV and computer monitor tubes case (2012)

\begin{tabular}{lcc}
\hline Firm & $\begin{array}{c}\text { Reduction under the } \\
\text { leniency programme }\end{array}$ & Fine (€ million) \\
\hline Chunghwa (Taiwan) & $100 \%$ & 0 \\
Samsung (South Korea) & $40 \%$ & 151 \\
Philips (Netherlands) & $30 \%$ & 313 \\
LG Electronics (South Korea) & $0 \%$ & 296 \\
Philips (Netherlands) and LG Electronics & $30 \%$ (for Philips) & 392 \\
(South Korea) & $10 \%$ & 39 \\
Technicolor (France) & $0 \%$ & 157 \\
Panasonic (Japan) & $0 \%$ & 28 \\
Toshiba (Japan) & $0 \%$ & 87 \\
Panasonic, Toshiba, and MTPD (Japan) & $0 \%$ & 8 \\
Panasonic and MTPD (Japan) & & \\
\hline
\end{tabular}

Source: European Commission (2012).

featured 'all the worst kinds of anticompetitive behaviour that are strictly forbidden' (European Commission 2012). Table 4.3 shows cartel participants' names, the locations of their headquarters, and fines for each participant. While Asian firms actively participated in this cartel, so did two EU firms, namely, Philips (the Netherlands) and Technicolor (France). As the table shows, the fine against Philips was as heavy as that imposed on LG Electronics. It is also important to note that the first whistle-blower, Chunghwa of Taiwan, was granted full immunity from the fine under the Commission's leniency programme. In other words, this case showed that firms can benefit from this programme regardless of their locations, if they provide relevant information about cartels and cooperate with the commission. These points indicate that the Commission strictly applied its competition rules in this case, irrespective of the nationality of firms.

The trucks case of 2016-2017 also offers insight into the discrimination issue. As of March 2021, this is the largest cartel in the EU's history in terms of total fines. The case began with an application for the leniency programme by a German truck maker, MAN, and then the European Commission carried out unannounced inspections of major European truck makers in January 2011 (European Commission 2016a). The investigation into this complex case continued for more than five years. In July 2016, the Commission finally decided to impose a total fine of 2.93 billion euros on four firms: DAF (the Netherlands), Daimler (Germany), Iveco (Italy), and Volvo/Renault (Sweden). ${ }^{4}$ MAN (Germany) received full immunity from the fine because it was the first whistle-blower. While the Commission decision was based on the settlement procedure, it was not applied to Scania (Sweden), which refused to cooperate with the commission during the investigation (European Commission 2017a). In September 2017, the Commission fined Scania 880 million euros for participating in the cartel. ${ }^{5}$ The cartel continued for 14 years from 1997 to 2011 and involved price coordination. The firms also coordinated the timing for the introduction 
of emission technologies for medium and heavy trucks to comply with the EU's increasingly strict environmental standards. This case has two important political implications. First, the case exhibited the Commission's strong commitment to the fight against cartels. As Table 4.1 shows, 4 out of the 10 heaviest fines per firm in the EU's history were against members of this cartel. Second, the case was politically important for the relationship between the EU and third countries because the Commission was investigating the US firm Google at that time (EURACTIV 2016). Since all firms fined in this landmark case are based in the $\mathrm{EU}$, this case disproves the widespread claim that the EU was disproportionately tough on non-EU firms.

These pieces of evidence in this section reveal three points. First, while EU cartel control has been internationalised to a great extent, EU firms are still fined more frequently than non-EU firms. Second, the vitamins case and TV and computer monitor tubes case are famous for the involvement of non-EU firms, but EU firms were also fined in both cases. Third, many of the highest cartel fines have been imposed on EU firms, as the trucks case illustrates. So far, the analysis of this section has mainly relied on the EU's official publications. To analyse EU cartel control from an external and more critical perspective, the next part explores discussions about this policy in Japan.

\subsubsection{Complaints from the Japanese business community}

The EU's strict cartel control has received widespread media coverage in Japan since the mid-2000s. This publicity was due to the frequent involvement of Japanese firms in the EU's cartel cases and severe fines imposed on them. By April 2015, fines of more than 100 million euros were levied on seven Japanese firms: Panasonic, NTN, YKK, Yazaki, Mitsubishi Electric, Toshiba, and Asahi Glass (METI 2015: 8). Some of them participated in cartels related to the automobile sector: NTN, Yazaki, and Asahi Glass were involved in bearings, automotive wire harnesses, and car glass cartels, respectively. ${ }^{6}$ These cases in the politically sensitive high-tech sector further increased the publicity of EU cartel control. Major Japanese newspapers such as Nihon Keizai Shimbun and Yomiuri Shimbun frequently reported on the involvement of Japanese firms in EU cartel cases and stressed the European Commission's significant regulatory influence. The Japan External Trade Organization (JETRO), which is an independent administrative institution of the Japanese government, published several reports on EU cartel control in the late 2000s. For example, one report analysed the European Commission's 2006 guideline on the calculation of fines (JETRO 2006), and another report studied major EU cartel cases that involved Japanese firms (JETRO 2007). These publications indicated a growing concern about the EU's severe cartel fines in the Japanese business community.

In addition, a legal issue that affected EU-Japan competition relations. Yomiuri Shimbun (2008) reported that the European Commission investigated a gas-insulated switchgear cartel $^{7}$ without notifying the Japan Fair Trade 
Commission (JFTC). The cartel involved not only EU firms such as Siemens but also Japanese firms, namely, Mitsubishi Electric, Toshiba, Fuji Electric, Hitachi, and Japan AE Power Systems. Therefore, the Commission was supposed to notify the JFTC when it started the investigation in 2004. However, the JFTC became aware of the case only when the Commission fined the cartel members in 2007. In this case, the Commission seems to have violated Article 2 of the 2003 EU-Japan agreement concerning cooperation on anticompetitive activities. Article 2(1) states that ' $\mathrm{t}$ ] he competition authority of each Party shall notify the competition authority of the other Party with respect to the enforcement activities that the notifying competition authority considers may affect the important interests of the other Party'. According to Article 2(2), typical enforcement activities that may affect the important interests of the other party include investigations into firms based on the other party's territory. The gas-insulated switchgear case meets this criterion because the firms investigated by the Commission include Japanese firms. The EU-Japan agreement has neither dispute settlement mechanisms nor sanction clauses, but the JFTC took the Commission's neglect of its notification obligation seriously. At the ICN's annual conference in Kyoto in April 2008, the JFTC staff asked senior competition officials of the European Commission to fulfil the obligations of the agreement (Yomiuri Shimbun 2008).

All these factors reinforced a widespread suspicion in the Japanese business community that EU competition policy was disproportionately tough on non-EU firms. Consequently, the European Commission's senior officials felt it necessary to explain their cartel policy to Japanese stakeholders more clearly. For example, then Competition Commissioner Neelie Kroes talked about the discrimination issue in an interview conducted by officials of the EU Delegation to Japan in 2009. The interview was published in Europe, a quarterly magazine the delegation used to publish as part of its public relations activity. Taking the car glass cartel case of $2008^{8}$ as an example, Kroes (2009: 7) stressed that EU competition policy did not discriminate against Japanese firms based on their nationality. While this case involved Japanese firms, she underlined that a record-breaking fine of 880 million euros was imposed on a French firm, Saint Gobain. Alexander Italianer, then Director-General of DG Competition, also commented on the discrimination issue four years later. He made a threefold argument in his speech at Keidanren (Japan Business Federation) in Tokyo on 22 November 2013 (Italianer 2013: 11-12). First, while Japanese firms were involved in 26 out of 82 cartel cases in the EU between January 1999 and November 2013, this relatively frequent involvement of Japanese firms should have been no surprise given the large volume of trade and investment between the EU and Japan. Second, Japanese firms were fined around 1.6 billion euros in these cases, representing only $9 \%$ of the EU's total cartel fines during the period. Third, he took the TV and computer monitor tubes cartel case mentioned above as an example to illustrate that the EU was 'just as tough on European firms that break the rules'. 
Specifically, Italianer stressed that the firm that received the largest fine (705 million euros) in this case was Dutch firm Philips, whereas smaller fines were imposed on Japanese firms, namely, Toshiba (114 million euros), Panasonic (252 million euros), and their joint venture MTPD (94 million euros).

Since the publication of the METI report in 2010, neither METI nor JFTC has raised the discrimination issue. Today, Japanese firms' complaints about EU cartel control centre on three other issues: the calculation of cartel fines, transparency of the decision-making process, and speed of case handling. ${ }^{9}$ The first common complaint of Japanese firms about EU cartel control is that the fines are excessively high. ${ }^{10}$ This issue became salient in the 2000s. As explained in Chapter 2, EU cartel control became much stricter during the tenure of Neelie Kroes, who served as the European Commissioner for Competition between 2004 and 2010. The adoption of the 2006 guidelines on the method of setting fines was crucial in this respect because it allowed the Commission to impose heavier fines on cartels. Today, it is common for Japanese firms to appeal Commission decisions to the General Court and Court of Justice of the EU, asking for the reduction of fines. The second major complaint, which is closely related to the first one, is that DG Competition has too much administrative discretion over cartel control. This issue was addressed in the 2011 annual report of the Japan Business Council in Europe (JBCE), which represents the interests of major multinational corporations of Japanese parentage operating in the European market. ${ }^{11}$ In this report, the JBCE (2011: 21) argued that, while the 2006 European Commission guidelines clarified the method for calculating cartel fines to a certain extent, the Commission should enhance the transparency of its decision-making process further. Specifically, the degree of cartel members' cooperation with competition authorities carried weight in the calculation of fines, but how the Commission measured 'cooperation' was not very clear, the JBCE argued. METI's report also points out that the EU's cartel fines are hard to predict because of the Commission's broad discretion (METI 2015: 30). The third common complaint is that the EU's cartel investigations could have been faster. It often takes three to four years, whereas cartel cases in Japan are usually concluded in one or two years. Firms have the right to appeal Commission decisions to EU courts, but the judicial process may also take many years. Therefore, the whole process can be very costly and time-consuming for firms involved in EU cartel cases.

In summary, a critical view of EU cartel control is widely shared among Japanese firms and business associations operating in Europe. In response, senior officials of the European Commission have argued that the policy is impartial and tough on all firms. Today, neither the Japanese government nor the Japanese business community voices concerns about nationality-based discrimination. Their main criticisms of EU cartel control focus on other regulatory issues, such as the method of setting fines, transparency and predictability of the decision-making process, and speed of investigations. 


\subsection{Abuse of dominance}

In the area of abuse of dominance, the European Commission regulates firms using three main policy tools: commitment decisions, prohibition decisions, and fines for non-compliance with Commission decisions. Commitment decisions are a kind of legal settlement between the Commission and the firms under investigation. When firms propose adequate remedies to address competition concerns, the Commission makes these remedies ('commitments') legally binding. Commitment decisions allow the Commission to shape the behaviour of larger firms based on negotiations while reducing the risk of lengthy court battles with these firms. When firms severely infringe on Article 102 of the TFEU (formerly Article 82 of the EC Treaty) or fail to propose adequate commitments to address competition concerns, the Commission may resort to prohibition decisions that forbid certain business conduct that infringes on Article 102 of the TFEU. Most prohibition decisions include the imposition of fines. Furthermore, the Commission has the power to impose fines on firms that have breached these types of Commission decisions. While commitment decisions may be useful for the Commission, they do not include financial penalties. Therefore, the following analysis focuses on Article 102 cases concluded by the other two types of decisions.

Table 4.4 provides a list of all cases between 1999 and 2020 that involved fines for the infringement of Article 102 of the TFEU or European Commission decisions related to this article. The author collected this data using the case search engine of the DG Competition website, which allows case searches by the type of Commission decision. While there were 18 prohibition decisions between 1999 and 2020, Table 4.4 excludes two because they did not involve fines. The Commission's 16 prohibition decisions with fines were addressed to 8 EU firms, 7 American firms, and 1 Norwegian firm. All three fines for non-compliance with Commission decisions were imposed on a single American firm, Microsoft. In the history of EU competition policy, Microsoft is the only company that has been fined for non-compliance with the Commission's decisions related to Article 102.

The table indicates three key points. First, EU firms are as likely to be fined as non-EU firms. A total of $50 \%$ of prohibition decisions had been addressed to EU firms. Second, the vast majority of non-EU firms fined by the European Commission were American firms. Third, the highest fines were imposed on four American firms: Intel, Microsoft, Google, and Qualcomm. However, this does not necessarily mean that the Commission has an anti-US bias. There are two factors in this pattern. First, the Commission targets the information and technology sector, which is vital for the EU's economic growth, as clearly stated in the EU's grand economic strategy, Europe 2020. This interpretation is consistent with the observation that the Commission tends to investigate competition cases in specific sectors. For example, three prohibition decisions in Table 4.4 involved telecommunication firms and two involved energy firms. ${ }^{12}$ Second, many American firms are highly competitive in the information and technology sector. If there were large European technology firms that abuse their 
TABLE 4.4 The European Commission's fines for abusive dominance, 1999-2020

\begin{tabular}{|c|c|c|c|c|}
\hline Year & Case & $\begin{array}{l}\text { Nationality } \\
\text { of firms }\end{array}$ & Fine $(€$ million $)$ & Decision types \\
\hline 2004 & Microsoft & American & 497 & \multirow[t]{16}{*}{ Prohibition } \\
\hline 2006 & Prokent/Tomra & Norway & 24 & \\
\hline 2007 & Telefonica S.A (Broadband) & Spain & 152 & \\
\hline 2009 & Intel & American & 1,060 & \\
\hline 2011 & Telekomunikacja Polska & Poland & 128 & \\
\hline 2014 & Slovak Telekom & $\begin{array}{l}\text { German and } \\
\text { Slovak }\end{array}$ & 70 & \\
\hline 2014 & $\begin{array}{l}\text { OPCOM/Romanian } \\
\text { Power Exchange }\end{array}$ & Romanian & 1 & \\
\hline 2016 & ARA foreclosure & Austrian & 6 & \\
\hline 2017 & Google Search (Shopping) & American & 2,424 & \\
\hline 2017 & Baltic rail & Lithuanian & 28 & \\
\hline 2018 & BEH gas & Bulgarian & 77 & \\
\hline 2018 & Google Android & American & 4,343 & \\
\hline 2018 & $\begin{array}{l}\text { Qualcomm (Exclusivity } \\
\text { payments) }\end{array}$ & American & 997 & \\
\hline 2019 & Qualcomm (Predation) & American & 242 & \\
\hline 2019 & $\begin{array}{l}\mathrm{AB} \text { InBev (Beer trade } \\
\text { restrictions) }\end{array}$ & $\begin{array}{l}\text { Belgian and } \\
\text { Dutch }\end{array}$ & 200 & \\
\hline 2019 & Google Search (AdSense) & American & 1,490 & \\
\hline 2006 & Microsoft & American & 281 & \multirow{3}{*}{$\begin{array}{l}\text { Fines for } \\
\text { non- compliance } \\
\text { with European } \\
\text { Commission } \\
\text { decisions }\end{array}$} \\
\hline 2008 & Microsoft & American & 899 & \\
\hline 2013 & Microsoft (Tying) & American & 561 & \\
\hline
\end{tabular}

Source: Collected by the author using the case search engine of DG Competition website: http:// ec.europa.eu/competition/elojade/isef/index.cfm, accessed 31 March 2021.

dominant positions in the digital market, the Commission would investigate these. However, in reality, Silicon Valley has been extremely successful in fostering dominant firms in the information and technology sector (Pratley 2017). These two factors contribute to the relative frequency of American firms in the Commission's prohibition decisions on the abuse of dominance.

In-depth case studies are useful to further examine whether the EU's abusive dominance control has an anti-American bias. Thus, the following section analyses two cases that involved Microsoft and three cases that involved Google. These cases are officially referred to as Microsoft, Microsoft (Tying), Google Search (Shopping), Google Android, and Google Search (AdSense). ${ }^{13}$ These were selected for case studies for three reasons. First, the European Commission repeatedly imposed severe fines on Microsoft and Google. Therefore, they are the most likely victims if the Commission discriminates against American firms. Second, the cases concerned key substantive issues that have significant implications for the digital economy. These issues include interoperability between computers, the tying of software products, online shopping, and online 
advertisements. Third, the Commission initially made a commitment decision on the Microsoft (Tying) case, but the company was fined later for a breach of this decision. Therefore, this case was selected for a case study. The other four cases were concluded by the Commission's prohibition decisions, as shown in Table 4.4.

\subsubsection{Microsoft: interoperability and tying}

Microsoft Corporation ('Microsoft') is an American software company with the largest market share in the personal computer (PC) operating system (OS) industry. On 10 February 2000, the European Commission requested Microsoft to provide them with information about the technical features of its PC OS, Windows 2000. The Commission took this initiative because of complaints from end-users, small and medium-sized enterprises in the information and technology sector, and competitors of Microsoft (European Commission 2000a). They complained that Microsoft tied Windows 2000 to other products, most notably the company's work group server OS. Some functions of Windows 2000 required connection to Microsoft's server OS. However, Microsoft did not disclose sufficient information about the link ('interface') between these products to competitors in the server OS market. Consequently, they were put at a serious disadvantage. Thus, the Commission sent a formal request for information to Microsoft to examine this case. Those who complained to the Commission wished to remain anonymous.

On 3 August 2000, the European Commission officially instituted legal proceedings against Microsoft. The Commission explained its preliminary findings in its first 'statement of objections' to Microsoft (European Commission 2000b). Microsoft had a market share of approximately 95\% in the PC OS market at the time. The company leveraged this dominant position onto the work group server OS market. Since most PCs were embedded into networks controlled by servers, 'interoperability' (i.e. the ability of PCs to operate with servers) was crucial in the computer software industry. Microsoft limited the interoperability of Windows 2000 to exclude competitors from the market. Specifically, Microsoft provided competitors with interface information only on a partial and discriminatory basis. The Commission's preliminary findings showed that this conduct ('refusal to supply') constituted a breach of Article 82 of the EC Treaty (now Article 102 of the TFEU). The European Competition Commissioner, Mario Monti, articulated the Commission's position on this case as follows:

The Commission welcomes all genuine innovation and advances in computer technology - wherever they come from [...] However, we will not tolerate the extension of existing dominance into adjacent markets through the leveraging of marker power by anti-competitive means and under the pretext of copyright protection.

(European Commission 2000b) 
The Commission acknowledged that this case was opened following a complaint by another American software company, Sun Microsystems ('Sun'), in December 1998 (European Commission 2000b). Sun requested Microsoft to disclose interface information about its OS software, such as Windows 95, Windows 98, and NT 4.0, but Microsoft rejected the request in October 1998. According to Sun, the launch of Windows 2000 in February 2000 was the final step in Microsoft's strategy to drive all major competitors out of the server OS market. In addition to the issue of interoperability raised by Sun, the Commission examined the issue of tying with its own initiative. Microsoft sold Windows 2000 with Windows Media Player - software that played music and video. The Commission's preliminary findings showed that Microsoft's tying of these products artificially reduced other firms' incentive to develop new media players (European Commission 2003). The Commission sent its third statement of objections to Microsoft on 6 August 2003 and provided the company its last opportunity to defend its conduct. Microsoft's chief executive, Steven Ballmer, visited Brussels in March 2004 to negotiate with the commission. However, they failed to reach a settlement. The Commission insisted on provisions that would significantly constrain Microsoft's future conduct, and Ballmer refused such provisions (Landler 2004).

On 24 March 2004, the Commission concluded that Microsoft abused its dominant position in the PC OS market and infringed on Article 82 of the EC Treaty (European Commission 2004). The Commission ordered Microsoft to provide competitors with interface information within 120 days and to offer a full-functioning version of Windows without Windows Media Player to PC manufacturers and end-users within 90 days. In addition, the Commission ordered Microsoft to propose a monitoring mechanism for these commitments and a monitoring trustee independent from the company. Furthermore, Microsoft was fined 497 million euros, a record against a single firm. ${ }^{14}$ This decision clearly showed the Commission's determination to scrutinise the anticompetitive business practices of dominant players in the information and technology sector. Microsoft's chief lawyer, Brad Smith, maintained that interface information related to server software was its intellectual property protected by law. Furthermore, he argued that Windows and other software products would not work properly without Windows Media Player (Dombey 2004; Kanter, Clark, and Wilke 2004).

On 7 June 2004, Microsoft appealed to the Court of First Instance and demanded the annulment of the European Commission's decision. Furthermore, Microsoft applied for a suspension of the orders specified in the decision. However, the president of the Court of First Instance dismissed this application on 22 December 2004 on the grounds that Microsoft failed to explain the urgency to obtain interim relief. ${ }^{15}$ Regarding the appeal of 7 June, the court upheld most parts of the Commission's decision on 17 September 2007. ${ }^{16}$ The court only annulled the Commission's order to Microsoft to propose a monitoring mechanism and to bear the costs associated with the appointment of a monitoring trustee. 
Despite the Commission's decision and the Court of First Instance's judgement, Microsoft refused to disclose interoperability information to competitors adequately. Consequently, the Commission imposed fines on Microsoft in July $2006^{17}$ and February $2008^{18}$ for non-compliance with the Commission's decision. These fines amounted to 1.17 billion euros in total. European Competition Commissioner Neelie Kroes stated that Microsoft was 'the first company in fifty years of EU competition policy that the Commission has had to fine for failure to comply with an antitrust decision' (European Commission 2008).

The European Commission instituted another legal proceeding against Microsoft on 14 January 2008 and sent a statement of objections to the company on 17 January 2009. This case concerned the tying of Microsoft's web browser, Internet Explorer, to Windows. Because of such tying, Internet Explorer was available on over $90 \%$ of PCs worldwide. The Commission considered that this conduct significantly distorted competition and discouraged innovation in the web browser market (European Commission 2009). This case was opened following a complaint by a Norwegian web browser developer, Opera Software ('Opera'), in December 2007. Microsoft's competitors and various business associations, such as the European Committee for Interoperable Systems (ECIS), welcomed the Commission's legal action (EURACTIV 2008, 2009). The ECIS, a non-profit association founded in 1989, represented the interests of information and communications technology software and hardware providers. The members of the association included major US firms such as Adobe, Corel, IBM, Opera, RealNetworks, Red Hat, and Sun, as well as a few non-US firms such as Corel (Canada) and Nokia (Finland).

After extensive discussions with the European Commission, Microsoft proposed to ensure that PC manufacturers and end-users in the EU would be able to install any web browser of their choice when they purchase Windows XP, Windows Vista, and Windows 7 software. Microsoft further committed not to retaliate against PC manufacturers that pre-install non-Microsoft web browsers on PCs. The Commission accepted these proposals and adopted a commitment decision under Article 9 of Regulation 1/2003 on 16 December 2009. ${ }^{19}$ The decision made Microsoft's proposals legally binding for five years. Consequently, Microsoft was obliged to invite Windows software users to choose from 12 web browsers, including Internet Explorer, Apple Safari, Google Chrome, Mozilla Firefox, and Opera (European Commission 2010a). However, the Commission later discovered that Microsoft did not adequately implement its commitments. One of the main OS products of the company, Windows 7 Service Pack 1, did not display a browser choice screen between February 2011 and July 2012. Hence, the Commission reopened legal proceedings on 17 July 2012 and fined Microsoft 561 million euros on 6 March 2013. ${ }^{20}$ This was the first time that the Commission fined a firm for non-compliance with agreed commitments in the area of abuse of dominance (European Commission 2013a).

The key finding of these case studies is that the main competitors of Microsoft were non-EU firms. The complainant in the first case was an American firm, 
Sun. Numerous firms that were admitted by the European Commission as 'interested third parties' were also Microsoft's American rivals such as Time Warner, Lotus, Novell, and RealNetworks (paragraph 11 of the Commission's decision). Regarding the second case, the complainant was a Norwegian firm, Opera, and a majority of Microsoft's competitors in the web browser market were American firms such as Google, Apple, and Mozilla. Thus, it is unlikely that the European Commission targeted Microsoft to foster dominant EU firms. No EU firm could compete with Microsoft in the OS, media player, and web browser markets.

The cases examined provide no evidence of nationality-based discrimination. They have demonstrated the Commission's commitment to the strict enforcement of competition law in the information technology sector and electronic commerce ('e-commerce'). Commitment is evident in the Commission's legal action against Microsoft, especially through the fines that were applied. Numerous press releases of the Commission also show its determination to fight the abuse of dominance in these economic sectors. For example, after sending the request for information to Microsoft in February 2000, the European Commission (2000a) stated that 'whoever gains dominance in the server software market is likely to control e-commerce too'. Similarly, after sending the first statement of objections to Microsoft in August 2000, the European Commission (2000b) commented that the resolution of this case was 'of the utmost importance as operating systems for servers constitute a strategic sector in the development of a global market for information technology and e-commerce'. The Microsoft cases paved the way for the Commission to tackle other serious cases in this sector (Damro and Guay 2016: 66). Recent cases involving Google have proved the continuing efforts of the EU to regulate monopolies in the digital market.

\subsubsection{Google: online shopping, mobile software, and online advertising}

As the court battle with Microsoft was ongoing, the European Commission opened investigations into the practices of another American technology company, Google. The Commission began legal proceedings against Google in November 2010, following complaints that the company had abused its dominant market position in the online search market (European Commission 2010b). The Commission informed Google of its preliminary findings in March 2013, and these findings showed that Google had violated Article 102 of the TFEU by privileging links to its own services within online search results and by imposing restrictive agreements about online advertisements on website providers and advertisers. Google proposed various commitments to address these concerns, and the Commission invited public comments on these commitments in April (European Commission 2013b). After further negotiations with the Commission, Google offered revised commitments in February 2014. The vice president of the European Commission in charge of competition policy, Joaquín Almunia, welcomed these commitments. He stated that Google's new 
proposal would adequately address the Commission's concerns, and that '[t]urning this proposal into a legally binding obligation for Google would ensure that competitive conditions are both restored quickly and maintained over the next years' (European Commission 2014). This indicated that Almunia was willing to make a commitment decision under Article 9 of Regulation 1/2003 to settle this case without resorting to financial penalties on Google. However, the Commission later changed its strategy and explored the possibility of imposing fines, most likely because numerous public and private actors had put pressure on the Commission (Damro and Guay 2016: 68). The critics in this case included not only Google's American rivals but also media firms such as Axel Springer (Germany) and Lagardère (France), government ministers of EU member states such as France and Germany, members of the European Parliament, and European Energy Commissioner Günther Oettinger.

Under the leadership of the new European Competition Commissioner, Margrethe Vestager, who succeeded Almunia in November 2014, the European Commission conducted further investigations into the alleged anticompetitive practices of Google. The Commission sent a statement of objections to Google on 15 April 2015, alleging that the company systematically favoured its online 'comparison shopping' service, Google Shopping, in its search results pages (European Commission 2015). On the same day, the Commission opened its second case against Google, which was concerned with restrictive practices in the mobile software market. Google has played a key role in the development of the Android mobile OS since the mid-2000s. While Android is an opensource system that can be freely used and developed by anyone, most smartphone and table producers active in the EU market use the Android mobile OS in conjunction with Google applications and services. Thus, the Commission examined whether Google had abused its dominant position in the Android mobile OS. Commissioner Vestager stressed the importance of mobile software in the digital economy. She commented that ' $[\mathrm{s}]$ martphones, tablets, and similar devices play an increasing role in many people's daily lives and I want to make sure the markets in this area can flourish without anticompetitive constraints' (European Commission 2015). After investigations, a statement of objections on this issue was delivered to Google on 20 April 2016 (European Commission 2016b). Three months later, the Commission opened its third case against Google, which was concerned with online advertisements. The Commission sent a statement of objections on this case to the company on 14 July 2016. The opening of the case followed a complaint that Google had imposed restrictions on the ability of certain website providers to display search advertisements of Google's competitors (European Commission 2016c). Today, numerous websites have search functions and display advertisements with search results. Through its 'AdSense for Search' platform, Google plays the role of an intermediary, connecting advertisers and website operators. These operators and Google receive a commission when users click advertisements associated with search results. 
The European Commission ultimately imposed severe financial penalties on Google three times between 2017 and 2019 for a breach of Article 102 of the TFEU. On 27 June 2017, the Commission fined Google 2.42 billion euros for abusing its dominant position in the general Internet search market. ${ }^{21}$ According to the Commission, Google privileged its comparison shopping service, Google Shopping, by showing it at or near the top of Internet search results. Conversely, Google disadvantaged rivals' shopping services. Even the most highly ranked rival service appeared on average only on the fourth page of Google's search results or even further down (European Commission 2017b). During the investigation into this case, Google stressed that it faced significant competition with online shopping sites such as Amazon.com and eBay (Fairless, Winkler, and Barr 2015). However, the Commission narrowly defined the relevant market and concluded that there was insufficient competitive pressure for Google in the comparison shopping market. ${ }^{22}$ On 18 July 2018, the Commission fined the company 4.34 billion euros for three restrictive practices concerning Android mobile software. ${ }^{23}$ First, Google tied its Android mobile devices to its 'Google Search' applications and 'Google Chrome' web browser. Second, Google granted significant financial incentives to mobile device manufacturers and mobile network operators on the condition that they exclusively pre-installed Google Search software. Third, Google prevented mobile device manufacturers from developing and distributing other types of Android OSs. These three types of abuse disadvantaged rival web browsers and search engines, such as Microsoft's Bing search engine on Windows Mobile devices, while reducing the incentive of mobile device producers to innovate new OSs (European Commission 2018). On 20 March 2019, the European Commission levied a fine of 1.49 billion euros on Google for its restrictive practices concerning online advertising. ${ }^{24}$ In this case, the company was accused of imposing restrictive clauses in contracts with website providers. The clauses prevent Google's rivals, such as Microsoft and Yahoo, from placing their search advertisements on these websites. In other words, Google significantly reduced competition in the online search advertising intermediation market. Google conducted this practice for a decade and ceased only after receiving the Commission's statement of objections in July 2016 (European Commission 2019).

These Google cases show two key points. First, unlike the Microsoft cases, the European Commission launched a formal investigation into Google following complaints by four firms and one association based in EU member states. According to paragraphs 39 to 42 of the Commission's 2017 decision, these were Foundem (United Kingdom); Ciao (Germany), whose complaint was transferred from the German competition authority to the Commission; eJustice (France); its parent company 1plusV (France), and a German association of business listings Verband freier Telefonbuchverleger (Germany). However, this does not necessarily mean that the Commission only represented the interest of EU firms. Other parties also communicated with the Commission during the investigative process. After the Commission initiated legal proceedings against Google in November 2010, numerous firms and groups submitted complaints or applied to 
be heard as third parties. According to paragraph 99 of the Commission's 2017 decision, there were 20 complainants and six interested third parties by October 2016. These included not only EU firms and business associations but also the European Consumer Organisation (BEUC) and US firms such as Microsoft, online platform provider Yelp, and online travel shopping company Expedia. Yelp's public policy director, Luther Lowe, stated that these US firms 'helped lead the charge by providing substantive evidence of Google's harm to consumers' (Foo and Auchard 2015).

Second, the chief beneficiaries of the European Commission's decisions on the second and third cases were Google's American rivals. One of the main competitors in the mobile devices market is Apple, as Google itself has stated. Another key competitor is Microsoft, which produces Windows Mobile devices with the Bing web browser. In the area of online search advertisements, Microsoft and Yahoo have been the main rivals of Google. If the main purpose of the European Commission was to foster dominant EU firms at the expense of US rivals, it could have concentrated on the first case, which was most relevant to the initial European complainants such as the comparison shopping company Foundem. These findings cast doubt on the claim that the European Commission's legal action against Google aimed to create dominant EU firms. It is more reasonable to interpret the Google cases as a sign of the Commission's determination to tackle the abuse of dominance in the information and technology sector, regardless of a firm's country of origin.

\subsection{Mergers}

Concerning mergers, it is important to understand the overall stable trend first. The EU's official statistics provide an overview of the European Commission's enforcement record. ${ }^{25}$ Between 1990 and 2020, the European Commission received 7,962 merger notifications. More than 7,000 cases were approved in Phase I of the review process with or without conditions, while some cases were withdrawn or considered out of the scope of EU merger control. The Commission initiated Phase II investigations into 282 cases. Regarding Phase II, 63 cases were cleared, and 137 cases received conditional approvals under Article 8(2) of Regulation 139/2004. Thirty cases were prohibited under Article 8(3) of the regulation, accounting for fewer than $0.4 \%$ of all notifications. These figures show that the European Commission has given green light to a large majority of cases since it assumed responsibility for merger control in 1990. This is a steady trend.

That being said, the economic impact of the European Commission's conditional approvals and prohibition decisions should not be underestimated. Regarding conditional approvals, firms' commitments are legally binding. The breach of these commitments may result in fines, which can be up to $10 \%$ of the firms' annual worldwide turnover. Prohibition decisions also have enormous impacts on firms, constraining their business strategies to a great extent. Table 4.5 provides a list of all mergers prohibited by the European Commission 
TABLE 4.5 Mergers disapproved by the European Commission, 1990-2020

\begin{tabular}{lll}
\hline Year & Case & Nationality of firms \\
\hline 1991 & Aerospatiale/Alenia/De Havilland & French, Italian, Canadian \\
1994 & MSG Media Service & German \\
1995 & RTL/Veronica/Endemol(HMG) & Dutch \\
1995 & Nordic Satellite Distribution & Norwegian, Danish, Swedish \\
1996 & Kesko/Tuko & Finnish \\
1996 & Saint-Gobain/Wacker-Chemie / NOM & French, German, Dutch \\
1996 & Gencor/Lonrho & South African, British \\
1997 & Blokker/Toys “R”us (II) & Dutch, American \\
1998 & Bertelsmann/Kirch/Premiere & German, Luxembourg \\
1998 & Deutche Telekom/BetaResearch & German \\
1999 & Airtours/First Choice & British \\
2000 & MCI WorldCom/Sprint & American \\
2001 & Volvo/Scania & Swedish \\
2001 & Tetra Laval/Sidel & Dutch, French \\
2001 & Schneider/Legrand & French \\
2001 & CVC/Lenzing & Luxembourg, Austrian \\
2001 & SCA/Metsä Tissue & Swedish, Finnish \\
2001 & General Electric/Honeywell & American \\
2004 & ENI/EDP/GDP & Portuguese, Italian \\
2007 & Ryanair/Aer Lingus & Irish \\
2011 & Olympic/Aegean Airlines & Greek \\
2012 & Deutche Börse/NYSE Euronext & German, American \\
2013 & Ryanair/Aer Lingus (III) & Irish \\
2013 & UPS/TNT Express & American, Dutch \\
2016 & Hutchison 3G UK/Telefónica UK & British \\
2017 & HeidelbergCement/Schwenk/Cemex Hungary/ & German, Hungarian, \\
& Cemex Croatia & Croatian \\
2017 & Deutsche Börse/London Stock Exchange Group & German, British \\
2019 & Siemens/Alstom & German, French \\
2019 & Tata Steel/ThyssenKrupp/JV & Indian, German \\
2019 & Wieland/Aurubis Rolled Products/ & German \\
& Schwermetall & \\
\hline & & \\
\hline & & \\
10 &
\end{tabular}

Source: Compiled by the author using the case search engine of DG Competition website: http:// ec.europa.eu/competition/elojade/isef/index.cfm, accessed 31 March 2021.

between 1990 and 2020. The data was collected by the author using the case search engine of DG Competition website, which allows case search by the type of Commission decisions. Three points should be noted. First, the decisions on Airtours/First Choice, Tetra Laval/Sidel, and Schneider/Legrand were overturned by the Court of First Instance in 2002, as explained in Chapter 2, but the EU courts usually uphold the Commission's decision to block mergers. Therefore, the Commission's decisions are crucial to the fate of notified mergers. Second, the table indicates that EU merger control has significant external implications. While 21 cases concerned purely European transactions, 9 cases involved non-EU firms. Two out of nine exclusively involved American firms. These two cases, MCI WorldCom/Sprint (2000) and GE/Honeywell (2001), exhibited the Commission's regulatory capacity to block mega mergers between non-EU 
firms. Third, the data indicates that EU merger control does not discriminate against non-EU firms. 70\% of cases disapproved by the Commission exclusively concerned EU firms. While this finding is significant, a further analysis is necessary to draw a conclusion about the discrimination issue.

Against this background, this section aims to ascertain whether the European Commission uses its merger rules to create larger EU firms at the expense of non-EU firms. If EU merger control has the characteristics of a strategic competition policy, the Commission may hinder the acquisition of EU firms by non-EU firms because such transactions make it difficult to foster large and internationally competitive EU firms. The Commission may also intervene more frequently in mergers that exclusively involve non-EU firms because these mergers may pose a threat to EU firms active in the same market.

Bradford, Jackson, and Zytnick (2018) explored this issue in their recent research. They conducted a statistical analysis to ascertain whether the European Commission is more likely to intervene when the acquirer is a non-EU firm and the firm acquired ('seller') is an EU firm. For this purpose, they first accessed the European Commission's unpublished and comprehensive data about more than 5,000 merger cases between 1990 and August 2014 and then made an original dataset using other economic databases as well. Next, the authors identified major factors that affect the likelihood of Commission interventions in mergers. The main factors they identified included transaction value, market size, degree of market concentration, and involvement of financial sponsors. Finally, by controlling these variables, the authors conducted a regression analysis to examine whether firm nationalities are correlated with the likelihood of Commission interventions. The authors found no correlation between them and disproved the claim that the Commission is more likely to hinder mergers involving EU sellers and non-EU acquirers (Bradford et al. 2018: 176-182). Their findings also show that the EU is less likely to intervene in mergers between non-EU firms than in mergers exclusively involving EU firms.

The following analysis aims to complement their research by conducting a case study of GE/Honeywell. It will be argued that even this controversial case shows no evidence of nationality-based discrimination, although it is widely thought of as the EU's exercise of competition rules for industrial purposes. GE/Honeywell provides insight into the analysis of the external aspects of EU merger control because it is the only case that exclusively involved non-EU firms and caused a serious political conflict. While the EU blocked another merger between US firms, MCI WorldCom and Sprint, the United States also disapproved it. Therefore, this case did not cause jurisdictional conflicts. Conversely, the EU and the United States reached opposing decisions on GE/Honeywell. The EU disapproved this merger, although the United States approved it with minor conditions. This is why the case provoked outrage in the United States and caused confrontation between EU and US policymakers.

There are two other reasons why GE/Honeywell was politicised to a great extent. The first reason was the tremendous size of the merger plan. GE's bid to 
acquire Honeywell was valued at 42 billion dollars. Second, the case raised the controversial issue of extraterritoriality. From a legal point of view, there was no doubt that the EU had jurisdiction over this merger because it clearly met the 'EU dimension' test defined by Regulation 139/2004. Both firms operate worldwide and are active in the EU market. Nevertheless, the EU's decision was widely criticised by US politicians, practitioners, and experts. In short, this was a reminder of the risk of interjurisdictional conflicts in the global economy and vividly illustrated the EU's regulatory capacity to block a merger between non-EU firms. Therefore, GE/Honeywell can make an interesting case study for a critical examination of the external dimension of EU merger control.

\subsubsection{GE/Honeywell}

GE is an industrial corporation operating in a wide range of areas such as aircraft engines, electrical appliances, and financial services. Honeywell manufactures aerospace-controlling computer systems ('avionics') and many other products such as automotive products and electronic materials. Honeywell put itself up for sale in mid-2000 because its business was not going well. GE and another American firm, United Technologies, bid for Honeywell, and GE ultimately won the competition. On 22 October 2000, GE and Honeywell signed an agreement by which the former would acquire the entire share capital of the latter. It was an agreement to make Honeywell a wholly owned subsidiary of GE. This 42-billion-dollar acquisition plan attracted wide media coverage because it would have been the world's largest industrial merger in history. Jack Welch, then chief executive of GE, postponed his retirement to complete this deal with Honeywell.

The European Commission received the notification of the merger plan on 5 February 2001 and launched a Phase-I review based on Regulation 4064/89, which was the EU's main merger rule at that time. In the Phase-I review, the Commission found a risk that the merger might restrict competition in the market for aircraft components such as jet engines, avionics, and non-avionics products. Therefore, on 1 March 2001 the Commission decided to open a full investigation into the proposed merger. In a press release, the Commission announced that its Phase-II review would focus on the question of whether the combination of GE's strong position in the engine market and Honeywell's strong market position in avionics and other products would lead to the creation or strengthening of dominance in these areas (European Commission 2001b). Under Regulation 4064/89, the Commission was obliged to make a final decision within four months after the launch of the Phase-II review. Meanwhile, the Antitrust Division of the US Justice Department also conducted a review of this merger because both GE and Honeywell are headquartered in the United States. When the European Commission decided to open the in-depth investigation, the review process on the American side was still ongoing. The US authorities approved the merger in May 2001. 
In the final weeks of the European Commission's review, the case was politicised to a great extent. On 14 June, GE proposed a set of measures as a concession to the European Commission to address competition concerns. However, GE failed to convince the Commission that these measures would fully address all issues. Since it became clear by mid-June that the Commission was very likely to block the merger, the US government began to publicly put political pressure on the EU. The US president, George W. Bush, expressed his concern about this case at a news conference in Moscow (Meller and Deutsch 2001). Furthermore, during his Gothenburg visit to the EU leaders, he urged them to give 'fair treatment' to GE and Honeywell (EURACTIV 2001a). Similarly, John Rockefeller, then chairman of the US Senate's aviation committee, sent a letter to the European Commission and stated that the EU's prohibition of the merger would have a 'chilling effect on transatlantic aerospace and aviation cooperation'. He also said that the United States might retaliate against the EU if it blocked the merger (EURACTIV 2001b). The European Commissioner for Competition, Mario Monti, and the European Commissioner for Transport, Loyola de Palacio, responded that the EU's merger review was based on hidden political motives and protectionism was 'wholly unfounded' (Mitchener and Murray 2001).

Despite such political pressure from the US government, the EU kept its position on the case. Commissioner Monti denounced the political pressure from the United States and stressed that the merger would be judged only on its economic and legal merit (EURACTIV 2001a). The EU's Advisory Committee, which consists of representatives of national competition authorities, supported the European Commission's draft decision and recommended the prohibition of the merger to the College of Commissioners on 25 June. While the committee's discussions are confidential, it was reported that some member states, including France and Germany, wanted to give more time to GE for further negotiations. Nevertheless, all member states except Ireland ultimately supported the Commission's draft decision (EURACTIV 2001a). During the investigative process, GE's Chairman and Chief Executive Officer Jack Welch met Commissioner Monti and attempted to reach an agreement. However, this attempt did not work mainly because Welch refused to accept the European Commission's request to sell off the company's financial and airplane-leasing division, GE Capital Aviation Services (GECAS) (Sorkin 2001). He thought that the merger would become meaningless if it involved too much divestment. On 28 June, representatives of GE had an 11-hour negotiation with Commission staff and proposed additional concessions, including the partial divestment of GECAS (EURACTIV 2001c). Again, this last-minute proposal, which was submitted after the official deadline, could not change the Commission's position.

The College of Commissioners unanimously decided to prohibit the proposed merger on 3 July, ${ }^{26}$ causing heated controversy both in the United States and Europe. Recognising the political sensitivity of this case, the European Commission attempted to justify its decision. For example, in its press release, the European Commission (2001c) emphasised that 'it was only the 15th time' 
that it had blocked a merger since 1990 and 'only the second time' that it had blocked a merger involving only American companies. ${ }^{27}$ Commissioner Monti put the blame for the failed merger on GE, saying that 'I regret that the companies were not able to agree on a solution that would have met the Commission's competition concerns'. He meant that GE should have agreed to divest some parts of its business, especially GECAS, as proposed by the European Commission. In addition, he denied that the EU's decision was based on a political motive rather than a purely economic and legal analysis. He remarked that 'each authority has to perform its own assessment' and the EU and US authorities drew different conclusions simply because they interpreted facts differently and forecast the effects of the merger in different ways (European Commission 2001c).

Despite these explanations, the European Commission's prohibition of the merger was widely criticised in the United States. There were many kinds of responses from American experts and policymakers. Some of them were based on politicians' outrage at the EU's interference in American economic affairs, while others highlighted differences between EU and US competition policies. ${ }^{28}$ One of the most outspoken critics of the European Commission was the US Treasury Secretary, Paul O'Neill. In an interview with the Washington Times, he said that EU merger control was 'flawed in the sense that the people who are making the judgments are not elected by anyone and their judgments are not subject to a judicial review or any kind of relief'. He added that 'there is a need to make some correction in their [regulatory and antitrust review] mechanism... especially in those cases where they are making judgments about business combinations of companies that are completely located outside their jurisdiction' (Washington Times 2001). He overlooked the fact that the United States had more experience than the EU in the extraterritorial application of competition law, including merger rules. In addition, he did not notice that firms have the right to appeal European Commission decisions to the EU courts. Nevertheless, his comment was not entirely unreasonable. Unlike the US competition authority, the European Commission can block mergers without prior court approval. The decision could be overturned by EU courts, but court battles often take many years. To O'Neill, this system and the Commission's dominant role in the handling of competition cases looked inappropriate. Criticisms from a more technical viewpoint were expressed by senior officials of the US competition authority, most notably Charles James, then Assistant Attorney General of the Antitrust Division, US Department of Justice. At the OECD Global Forum on Competition in Paris on 17 October 2001, he argued that the economic analysis employed by the EU in the GE/Honeywell case was 'neither soundly grounded in economic theory nor supported by empirical evidence, but rather, [was] antithetical to the goals of sound antitrust enforcement'. He added that '[w]e fear that it will result in some procompetitive mergers being blocked, and others never being attempted, to the detriment of consumers in many countries' (James 2001). It is very rare that the US government criticises other countries' competition decisions to this extent. 


\subsubsection{Causes and implications of the transatlantic divide}

Studies suggest three key reasons why the European Commission and the US Department of Justice made opposing decisions in this case. First, the European Commission and the US Department of Justice communicated extensively during their investigations based on the competition cooperation agreement of 1991, as both sides repeatedly said. Therefore, it is unreasonable to claim that the transatlantic divide resulted from a lack of communication between competition authorities (Morgan and McGuire 2004: 42).

Second, one of the determining factors that contributed to the transatlantic divide was the difference between EU and US merger policies in terms of substantive assessment. On the one hand, the US authority used the 'substantial lessening of competition' test for the assessment and took into consideration the merger's positive economic effects ('efficiency gains'). On the other hand, the EU authority used the 'dominance test' for assessment and exclusively focused on the merger's anticompetitive effects (Morgan and McGuire 2004: 51). In other words, the United States and the EU focused on consumer welfare and the maintenance of market competition, respectively. Another difference is that the US authority exclusively assessed short-term economic effects, whereas the EU evaluated long-term effects as well (Vivest and Staffiero 2008: 32). Specifically, the European Commission was concerned about the merger's conglomerate effects, such as the bundling of products in related markets. ${ }^{29}$ Many experts both in Europe and the United States criticised this economic analysis, saying that it was speculative and not supported by concrete evidence (Baxter, Dethmers, and Dodoo 2006; Morgan and McGuire 2004). In other words, after the merger, GE could have bundled its aircraft engines and related services with Honeywell's avionics products, but that was just a possibility, critics said.

Third, another key factor in the outcome of the merger was GE's poor negotiation strategy (Damro and Guay 2016: 50-51; Sorkin 2001). GE led by Welch rushed to make a deal with Honeywell because GE's American rival, United Technologies, was also considering the acquisition of Honeywell. The merger negotiation was concluded in only three days, indicating that GE did not conduct a sufficient legal assessment of the deal before signing it. The company could have consulted with counsel in Brussels before concluding the agreement. Furthermore, while merging firms may have held confidential meetings with the European Commission before formal merger notifications, GE did not take this opportunity. Instead, GE launched a publicity campaign, especially one of media exposure, while expecting the US government to put pressure on the European Commission. This strategy clearly failed and showed GE's limited understanding of the Commission's commitment to autonomous decision-making.

While the GE/Honeywell merger was abandoned, the European Commission's decision was severely criticised by the Court of First Instance four years later (Baxter et al. 2006). In December 2005, the court rejected the Commission's argument about the merger's conglomerate effects. ${ }^{30}$ According to the judgement, 
the Commission failed to show how exactly the financial strength and vertical integration resulting from the merger would lead to the abuse of dominance. Consequently, the court concluded that 'the Commission made a manifest error of assessment in holding that the financial strength and vertical integration of the merged entity would bring about the creation or strengthening of dominant positions on the markets for avionics or non-avionics products' (paragraph 364). The court also denounced the Commission's claim about the possibility of bundling by the merged entity. According to the judgement, the Commission failed to explain why bundling was likely to occur after the merger. The Commission also overlooked the deterrent effect of Article 82 TEC (now Article 102 TFEU) on the abuse of dominant positions (paragraph 387). For these reasons, among others, the court concluded that 'the Commission made a manifest error of assessment in finding that the merged entity's future use of bundling would lead to the creation or strengthening of dominant positions on the markets for avionics or non-avionics products, or to the strengthening of GE's pre-merger dominant position on the markets for large commercial jet aircraft engines' (paragraph 473). The only major point supported by the court was that the merger would have had anticompetitive effects because of horizontal market integration. While the Commission's decision to prohibit the merger was upheld for this reason, the judgement posed a serious challenge to the credibility of the Commission's handling of merger cases.

The GE/Honeywell case provides three insights into the external dimension of EU merger control. First, with regard to the review of individual competition cases, the European Commission is resistant to external political pressure, even when it comes from the United States. This is remarkable, but not entirely new. It was already evident in a preceding case in the aerospace industry, Boeing/McDonnell Douglas in 1997 (Damro and Guay 2016: 42-45). The Commission stood firm in its position and imposed conditions on this merger between American firms, although the Clinton administration and US Congress strongly condemned the Commission's interference in the case.

Second, there is no clear evidence that the EU blocked the GE/Honeywell merger to protect European firms. When the European Commission reviewed the merger, then US Senator Ernest Hollings accused the Commission of using its merger rules as a tool to protect and promote European industry at the expense of US competitors (Wilke 2001). However, those who complained to the Commission about the merger included not only EU firms, such as RollsRoyce (United Kingdom), but also American ones, such as United Technologies and Rockwell International (Wilke 2001). Therefore, it is hard to interpret the EU's merger prohibition as the use of competition policy for industrial policy purposes.

Finally, the GE/Honeywell case revealed that the main problem of EU merger control is not discrimination against non-EU firms but rather the quality of the European Commission's economic and legal analysis. In fact, the Commission makes errors at times, regardless of the nationality of firms. During 
Commissioner Monti's tenure between September 1999 and November 2004, the European Commission prohibited eight mergers, and the Court of First Instance overturned four of the eight decisions (Levy 2005: 100). It is ironic because Monti was the first European Commissioner for Competition with work experience as a professor of economics. The four overturned decisions involved both European and non-EU firms. They were Airtours (United Kingdom)/First Choice (United Kingdom), Schneider (France)/Legrand (France), Tetra Laval (Sweden/Switzerland)/Sidel (France), and MCI WorldCom (United States)/ Sprint (United States). ${ }^{31}$ Mainly in response to these judgements and the controversy over GE/Honeywell, the European Commission conducted a series of reforms, as explained in Chapter 2. The reforms included the appointment of a Chief Competition Economist, the introduction of new guidelines on the assessment of horizontal mergers, and the adoption of Regulation 139/2004, which allows the Commission to examine merger cases using a more flexible time frame. It should be noted that the Commission also makes errors at times in the opposite direction. During the term of Monti's successor, Neelie Kroes, the court overturned the Commission's approval of a merger. The Commission approved a proposed joint venture between subsidiaries of Sony (Japan) and Bertelsmann (Germany) in 2004, ${ }^{32}$ but the court ordered the Commission in 2006 to assess the case again. The judgement harshly criticised the Commission's decision, saying that it relied on insufficient evidence and a weak assessment with manifest errors. ${ }^{33}$ Consequently, the Commission had to reopen the case for a thorough analysis. The notified merger was finally clarified in 2007. As all these cases illustrate, Commission decisions have been subject to close scrutiny, especially since the early 2000s.

In summary, the European Commission's prohibition of GE/Honeywell is best understood as a controversial decision that was made when the Commission was struggling with a transition from a legalistic approach to a new approach that relies more heavily on economic analyses. On the one hand, the decision-making process has demonstrated that the Commission is resistant to external political pressure to a great extent. On the other hand, EU court decisions and discussions on both sides of the Atlantic caused the Commission to substantially revise its merger rules. Some politicians claim that GE/Honeywell exemplified the Commission's discrimination against American firms, but this opinion remains speculative. The main cause of the EU-US disagreement in this case was the difference between their merger policies in terms of substantive assessments.

\section{Conclusion}

Past and present European Commissioners for Competition have stressed the impartiality of EU competition policy at times in their public speeches. One of the leading proponents of this discourse is Margrethe Vestager, the European Commission's Executive Vice-President for 'A Europe Fit for the Digital Age' 
and Competition. For example, in her speech in New York on 20 April 2015 she stated the following:

Deng Xiaoping [said] that it does not matter whether a cat is black or white as long as it catches mice. The antitrust enforcer version of this saying should be that it does not matter where the company comes from, as long as it competes - by the rules.

(Vestager 2015b)

As articulated in this statement, the European Commission's official line is that the EU enforces its competition law regardless of the nationality of firms. According to this argument, the EU's main goal is to keep its internal market open, competitive, and level because that would result in greater competitiveness and more innovation, at least in the long run.

By using data from both EU and non-EU sources, this chapter investigated whether EU competition policy is non-discriminatory, as the EU claims. The analysis focused on three policy areas: cartels, abuse of dominance, and mergers. The empirical findings show that the European Commission treats EU and non-EU firms equally. This is most likely because, as suggested in Chapter 1, the EU's priority is the fight against anticompetitive business practices rather than the protection of EU firms from their non-EU rivals.

Regarding cartel control, the sharp increase in fines since the 2000s attracted widespread media coverage in third countries, particularly in Japan. Nevertheless, the EU's strict approach to cartels is a general trend and does not necessarily mean that the European Commission imposes higher fines on non-EU firms. The quantitative data and case studies show no evidence of nationality-based discrimination. The Japanese government and business community have been critical of EU cartel control for other reasons, but they do not raise the discrimination issue any longer.

In the area of abuse of dominance, a relatively large number of American firms have been subjected to the European Commission's commitment decisions and prohibition decisions. This fact is attributable to two main factors, namely, the EU's focus on the regulation of digital markets and the strong presence of American firms in these markets. As the Microsoft and Google cases illustrate, the main rivals of American firms fined by the European Commission are often headquartered in the United States. Therefore, it is not reasonable to argue that the EU targets non-EU firms to create or strengthen dominant EU firms.

With regard to mergers, the European Commission regularly clears a vast majority of merger notifications, and the number of prohibition decisions is comparatively small. However, these decisions are insightful because they illustrate how the European Commission treats large mergers, including those that exclusively involve non-EU firms. There is a persistent claim that the hidden goal of EU merger control is the protection of EU firms; however, this claim is not based on concrete evidence. As the case study of GE/Honeywell has shown, the main 
cause of occasional jurisdictional conflicts between the EU and the United States is not discrimination, but the difference between their merger policies in terms of substantive assessment. It should be noted that the European Commission's controversial merger decisions were mainly made during the transitional period, the time when DG Competition was trying to shift from a legalistic approach to a new approach that relies more on economic analyses. The main challenges faced by the European Commission have been the improvement of its economic analysis and provision of sufficient evidence to support that analysis.

To provide a balanced argument, this chapter has reviewed discussions in Japan and the United States over the external aspects of EU competition policy. These discussions were mainly prompted by high-profile cases, especially those studied in this chapter. The discrimination issue was occasionally raised in both countries. However, claims about the issue have not been developed, and they remain speculative. More convincing criticism of EU competition policy centres on two broad issues. The first is the problem of governance, including the insufficient transparency of the decision-making process, comparatively slow case handling, and the problematic legal and economic analysis of individual cases. The second major issue is divergent procedures and substantive rules across jurisdictions, including the EU, the United States, and Japan.

Overall, the empirical findings support the central argument of this book that EU competition policy is 'stringent' rather than 'strategic'. In theory, the European Commission could have discriminated against non-EU firms to enhance the international competitiveness of EU firms, but that is not the case. The Commission is tough on all firms, regardless of their country of origin. This implies that the main goal of EU competition policy is the maintenance of market competition rather than the direct creation and strengthening of dominant EU firms.

\section{Notes}

1 These fines were imposed on AU Optronics Corporation of Taiwan (Taiwan); Roche (Switzerland); Yazaki Corporation (Japan); Bridgestone Corporation (Japan); LG Display (South Korea) and its American subsidiary, Société Air France (France); Koninklijke Luchtvaart Maatschappij (the Netherlands); Korean Air Lines (South Korea); British Airways (United Kingdom); Samsung Electronics Company (South Korea) and its American subsidiary; and BASF (Germany).

2 Case COMP/E-1/37.512, Vitamins, Commission decision of 21 November 2001, OJ L6/1, 10 January 2003.

3 Case COMP/39.437, TV and Computer monitor tubes, Commission decision of 5 December 2012, OJ C303/13, 19 October 2013.

4 Case AT.39824, Trucks, Commission decision of 19 July 2016.

5 Case AT.39824, Trucks, Commission decision of 27 September 2017.

6 Cases COMP/39.125, Car glass; AT.39922, Bearings; AT.39748, Automotive Wire Harnesses.

7 Case COMP/F/38.899, Gas Insulated Switchgear.

8 Case COMP/39.125, Car glass, Summary of Commission decision of 12 November 2008, OJ C173/13, 25 July 2009. 
9 This is based on an interview with a First Secretary of the Japanese Mission to the EU in Brussels on 23 May 2014.

10 Note that there is an opposing opinion on this issue. Some experts, especially economists, argue that the European Commission's fines should be even higher to effectively deter cartels.

11 The JBCE was established in 1999. It makes policy recommendations to EU institutions. As of March 2021, the JBCE represents the interests of 90 multinational companies of Japanese parentage active in Europe. For more details, see JBCE (2020) and the JBCE website: https://www.jbce.org/about-us/who-we-are/ about-jbce/.

12 Telefonica S.A (broadband), Telekomunikacja Polska, and Slovak Telekom cases concern the telecommunications sector. OPCOM/Romanian Power Exchange and $\mathrm{BEH}$ gas cases concern the energy sector.

13 Cases COMP/C-3/37.792, AT.39530, AT.39740, AT.40099, and AT.40411.

14 Case COMP/C-3/37.792, Microsoft, Commission Decision of 24 May 2004, OJ L/32/23, 6 February 2007.

15 Order of the President of the Court of First Instance, Microsoft v. Commission, ECLI:EU:T:2004:372.

16 Microsoft v. Commission, ECLI:EU:T:2007:289.

17 Case COMP/C-3/37.792, Microsoft, Summary of Commission Decision of 12 July 2006, OJ C138/10, 5 June 2008.

18 Case COMP/C-3/37.792, Microsoft, Commission Decision of 27 February 2008, OJ C166/20, 18 July 2009.

19 Case COMP/39.530, Microsoft (Tying), Summary of Commission Decision of 16 December 2009, OJ C/36/7, 13 February 2010.

20 Case COMP/39.530, Microsoft (Tying), Summary of Commission Decision of 6 March 2013, OJ C120/15, 26 April 2013.

21 Case AT.39740, Google Search (Shopping), Commission decision of 27 June 2017, C(2017)4444 final.

22 For a critical analysis of this decision, see Eben (2018).

23 Case AT.40099, Google Android, Commission decision of 18 July 2018, C(2018) 4761 final.

24 Case AT.40411, Google Search (AdSense), Commission decision of 20 March 2019.

25 DG Competition's website, https://ec.europa.eu/competition/mergers/statistics.pdf, accessed 31 March 2021.

26 Case COMP/M.2220, General Electric/Honeywell, Commission decision of 3 July 2001, OJ L48/1, 18 February 2004.

27 The first merger between American companies blocked by the EU was MCI WorldCom/Sprint in 2000 (Case COM/M.1741). The United States also prohibited it, and that is the difference between this case and GE/Honeywell.

28 See Gerber (2003), who surveyed US responses to the EU's GE/Honeywell decision and reflected on their underlying assumptions.

29 For more details, see Giotakos et al. (2001), which was written by staff members of DG Competition.

30 Case T-210/01, General Electric v. Commission, ECLI:EU:T:2005:456.

31 Case COMP/M.1542, Airtours/First Choice, Commission decision of 22 September 1999, OJ L93/1, 13 April 2000; Case COMP/M.2283, Schneider/Legrand, Commission decision of 30 January 2002, OJ L101/134, 6 April 2004; Case COMP/M.2416, Tetra Laval/Sidel, Commission decision of 30 October 2001, OJ L42/13, 13 February 2004; COMP/M.1741, WorldCom/Sprint, Commission decision of 28 June 2000, OJ L300/1, 18 November 2003.

32 Case COMP/M.3333, Sony/BMG, Commission decision of 19 July 2004, OJ L62/30, 9 March 2005.

33 Case T-464/04, Impala v. Commission, ECLI:EU:T:2006:216. 


\section{References}

Baxter, S., Dethmers, F. and Dodoo, N. (2006). The GE/Honeywell Judgment and the Assessment of Conglomerate Effects: What's New in EC Practice? European Competition Journal, 2(1), pp. 141-167.

Bradford, A., Jackson, R. J. Jr. and Zytnick, J. (2018). Is E.U. Merger Control Used for Protectionism? An Empirical Analysis. Journal of Empirical Legal Studies, 15(1), pp. 165-191.

Cremieux, P. and Snyder, E. A. (2016). Enforcement of Anticollusion Laws Against Domestic and Foreign Firms. Journal of Law and Economics, 59(4), pp. 775-803.

Damro, C. and Guay, T. R. (2016). European Competition Policy and Globalization. Basingstoke: Palgrave Macmillan.

Dombey, D. (2004). Brussels Spells Out Future for Microsoft: The European Commission Delivers its Own Rule Book in an Effort to Transform the Way the Software Giant Conduct. Financial Times, 26 March.

Eben, M. (2018). Fining Google: A Missed Opportunity for Legal Certainty? European Competition Journal, 14(1), pp. 129-151.

EURACTIV. (2001a). Advisory Committee Blocks GE-Honeywell Merger. 26 June.

EURACTIV. (2001b). US Anger over EU's Handling of GE-Honeywell Merger. 21 June.

EURACTIV. (2001c). EU Rejects Last-minute GE-Honeywell Offer. 29 June.

EURACTIV. (2008). EU Opens New Antitrust Probe Against Microsoft. 15 January.

EURACTIV. (2009). Brussels Threatens Microsoft with Fresh. 19 January.

EURACTIV. (2016). Truck Cartel to Get Heavy EU Fine: Sources. 18 July.

European Commission. (2000a) Commission Examines the Impact of Windows 2000 on Competition, Press Release, IP/00/141.

European Commission. (2000b). Commission Opens Proceedings Against Microsoft's Alleged Discriminatory Licensing and Refusal to Supply Software Information, Press Release, IP/00/906.

European Commission. (2001a). Commission Imposes Fines on Vitamin Cartels, Press Release, IP/01/1625.

European Commission. (2001b). Commission Opens Full Investigation into the General Electric/Honeywell Merger. Press Release, IP/01/298.

European Commission. (2001c). The Commission Prohibits GE's Acquisition of Honeywell, Press Release, IP/01/939.

European Commission. (2003). Commission Gives Microsoft Last Opportunity to Comment Before Concluding its Antitrust Probe, Press Release, IP/03/1150.

European Commission. (2004). Commission Concludes on Microsoft Investigation, Imposes Conduct Remedies and a Fine, Press Release, IP/04/382.

European Commission. (2008). Antitrust: Commission Imposes $€ 899$ Million Penalty on Microsoft for Non-compliance with March 2004 Decision, Press Release, IP/08/318.

European Commission. (2009) Antitrust: Commission Confirms Sending a Statement of Objections to Microsoft on the Tying of Internet Explorer to Windows, Memo, MEMO/09/15.

European Commission. (2010a). Antitrust: Commission Welcomes Microsoft's Roll-out of Web Browser Choice, Press Release, IP/10/216.

European Commission. (2010b). Antitrust: Commission Probes Allegations of Antitrust Violations by Google, Press Release, IP/10/1624.

European Commission. (2012). Antitrust: Commission Fines Producers of TV and Computer Monitor Tubes $€ 1.47$ Billion for Two Decade-long Cartels, Press Release, IP/12/1317. 
European Commission. (2013a). Antitrust: Commission Fines Microsoft for Noncompliance with Browser Choice Commitments, Press Release, IP/13/196.

European Commission. (2013b). Antitrust: Commission Seeks Feedback on Commitments Offered by Google to Address Competition Concerns, Press Release, IP/13/371.

European Commission. (2014). Antitrust: Commission Obtains from Google Comparable Display of Specialised Search Rivals, Press Release, IP/14/116.

European Commission. (2015). Antitrust: Commission Sends Statement of Objections to Google on Comparison Shopping Service; Opens Separate Formal Investigation on Android, Press Release, IP/15/4780.

European Commission. (2016a). Antitrust: Commission Fines Truck Producers $€ 2.93$ Billion for Participating in a Cartel, Press Release, IP/16/2582.

European Commission. (2016b). Antitrust: Commission Sends Statement of Objections to Google on Android Operating System and Applications, Press Release, IP/16/1492.

European Commission. (2016c). Antitrust: Commission Takes Further Steps in Investigations Alleging Google's Comparison Shopping and Advertising-related Practices Breach EU Rules, Press Release, IP/16/2532.

European Commission. (2017a). Antitrust: Commission Fines Scania $€ 880$ Million for Participating in Trucks Cartel, Press Release, IP/17/3502.

European Commission. (2017b). Antitrust: Commission Fines Google €2.42 Billion for Abusing Dominance as Search Engine by Giving Illegal Advantage to Own Comparison Shopping Service, Press Release, IP/17/1784.

European Commission. (2018). Antitrust: Commission Fines Google €4.34 Billion for Illegal Practices Regarding Android Mobile Devices to Strengthen Dominance of Google's Search Engine, Press Release, IP/18/4581.

European Commission. (2019). Antitrust: Commission Fines Google $€ 1.49$ Billion for Abusive Practices in Online Advertising, Press Release, IP/19/1770.

Fairless, T., Winkler, R. and Barr, A. (2015). Europe Charges Google Over Searches: Antitrust Complaint Tied to Firm's Comparison-shopping Service Could Lead to Broader Action. Wall Street Journal. 16 April.

Foo, Y. C. and Auchard, E. (2015). EU Antitrust Case Against Google Based on 19 Complainants: Sources. Reuters. 27 April.

Gerber, D. J. (2003). The European Commission's GE/Honeywell Decision: U.S. Responses and Their Implications. Zeitschrift für Wettbewerbsrecht, 1(1), pp. 87-95.

Giotakos, D., Petitt, L., Garnier, G. and De Luyck, P. (2001). General Electric/ Honeywell: An Insight into the Commission's Investigation and Decision. Competition Policy Newsletter, 3, pp. 5-13.

Italianer, A. (2013). European Competition Policy and Japan. Speech at KEIDANREN (Japan Business Federation), Tokyo, 22 November [Online]. Available at: https://ec. europa.eu/competition/speeches/text/sp2013_10_en.pdf [accessed: 31 March 2021].

James, C. (2001). International Antitrust In The 21st Century: Cooperation And Convergence. Speech at the OECD Global Forum on Competition, Paris, 17 October [Online]. Available at: https://www.justice.gov/atr/speech/international-antitrust21st-century-cooperation-and-convergence [accessed: 31 March 2021].

JBCE. (2011). 2011 年 JBCE 報告書.

JBCE. (2020). EU-Japan Cooperation: Catalyst for a Strong Recovery: JBCE Annual Report 2020 [Online]. Available at: https://www.jbce.org/wp-content/ uploads/2020/11/JBCE-RA20-web.pdf?x59080 [accessed: 31 March 2021].

JETRO. (2006). カルテル事件等に対する制裁金算定ガイドラインの改定 [Online]. Available at: https://www.jetro.go.jp/ext_images/jfile/report/05001346/05001346_ 001_BUP_0.pdf [accessed 31 March 2021]. 
JETRO. (2007). EU における最近のカルテル制裁の動向. [Online]. Available at: https://www.jetro.go.jp/ext_images/jfile/report/05001446/05001446_001_BUP_0. pdf [accessed 31 March 2021].

Kanter, J., Clark, D. and Wilke, J. R. (2004). EU Imposes Sanctions on Microsoft - Fine, Disclosure Penalties Aim to Undercut Dominance; Continued Pressure Signaled. Wall Street Journal. 25 March.

Kroes, N. (2009). 消費者に利益もたらす競争政策. Europa (Delegation of the European Union to Japan), 257, p. 7.

Landler, M. (2004). A Slayer of Monopolies, One Corporation at a Time. New York Times. 25 March.

Levy, N. (2005). Mario Monti's Legacy in EC Merger Control. Competition Policy International, 1(1), pp. 99-132.

Meller, P. and Deutsch, C. H. (2001). Europe Opens Door For G.E., Just Slightly. New York Times. 16 June.

METI. (2010). 競争法コンプライアンス体制に関する研究会報告書一国際的な競争法 執行強化を踏まえた企業·事業者団体のカルテルに係る対応策.

METI. (2015). 各国競争法の執行状況とコンプライアンス体制に関する報告書一国際 的な競争法執行強化を踏まえた企業·事業者団体のカルテルに係る対応策.

Mitchener, B. and Murray, M. (2001). EU's Monti Stands Firm On GE Deal: Commissioner Rejects Claims That Review Was Politically Tainted. Wall Street Journal. 27 June.

Morgan, E. J. and McGuire, S. (2004). Transatlantic Divergence: GE-Honeywell and the EU's Merger Policy. Journal of European Public Policy, 11(1), pp. 39-56.

OECD. (2014). Challenges of International Cooperation in Competition Law Enforcement [Online]. Available at: https://www.oecd.org/daf/competition/ Challenges-Competition-Internat-Coop-2014.pdf [accessed: 31 March 2021].

Pratley, N. (2017). Google Fine: EU is not Waging Underhand Trade War Against US Tech Firms; The European Commission is Not Showing Signs of Anti-American Bias; Its Actions will Benefit Consumers Worldwide. Guardian. 27 June.

Sorkin, A. R. (2001). Failure to Acquire Honeywell Is Sour Finish for G.E. Chief. New York Times. 3 July.

Vestager, M. (2015a). Independence is Non-negotiable. Speech at the Chatham House Competition Policy Conference, London, 18 June [Online]. Available at: https:// wayback.archive-it.org/12090/20191129202709/https://ec.europa.eu/commission/ commissioners/2014-2019/vestager/announcements/independence-non-negotiable_ en [accessed: 31 March 2021].

Vestager, M. (2015b). Enforcing Competition Rules in the Global Village. Speech at New York University, New York, 20 April [Online]. Available at: https:// wayback.archive-it.org/12090/20191129202144/https://ec.europa.eu/commission/ commissioners/2014-2019/vestager/announcements/enforcing-competitionrules-global-village_en [accessed: 31 March 2021].

Vivest, X. and Staffiero, G. (2008). The GE-Honeywell Merger in the EU. Occasional Paper (IESE Business School), OP-160, pp. 1-36.

Washington Times (2001). O’Neill Rebukes EU for Blocking GE Merger. 3 July.

Wilke, J. (2001). U.S. Antitrust Chief Criticizes EU Decision to Reject Merger of GE and Honeywell. Wall Street Journal. 5 July.

Yomiuri Shimbun (2008). 重電カルテル 欧州委、日本へ通達急る 公取、数十億円取れ ず. 14 April. 


\section{SYSTEMIC CONSTRAINTS ON THE EU'S ROLE AS A GLOBAL RULE-MAKER}

The empirical findings of Chapters 3 and 4 suggest that the EU pursues a non-discriminatory and comparatively strict competition policy with the exception of state aid control. Such stringent regulations could put EU firms at a competitive disadvantage. Thus, this chapter explores the proposition that the EU externally promotes competition law and policy to alleviate the competitioncompetitiveness dilemma. Section 1 explains the key political and economic reasons for the EU's commitment to external competition relations. Section 2 provides an in-depth analysis of the EU's failed attempt to create the WTO competition law from the late 1990s to early 2000s. Furthermore, this section examines the implications of two competition-related trade disputes brought to the WTO: Japan-Film (1996-1998) and Mexico-Telecoms (2002-2004). Section 3 first explains the ICN's history and governance mode, and based on this insight, examines how this global regulatory network constrains the EU's role as a global rule-maker. Subsequently, the section provides an overview of the EU's current institutional instruments for bilateral and interregional competition relations and analyses how useful they are for the EU's external transfer of its competition rules. Overall, evidence shows that the EU has been consistently committed to the international promotion of competition law and policy, as hypothesised in Chapter 1. However, the EU's rule transfer capability is significantly constrained by systemic constraints, such as the WTO negotiation deadlock, a growing trend for voluntary competition cooperation based on soft law, and competition with the United States. 


\subsection{Political and economic reasons for the EU's external engagement}

The EU's external competition policy has three key aspects. First, the EU applies its competition law extraterritorially. Second, the competition authorities of the EU and its member states cooperate with their non-EU counterparts at the bilateral, interregional, and multilateral levels. Third, in the context of its enlargement policy, the EU asks candidate states and potential candidate states to establish competition laws and institutions compatible with its own supranational competition law.

The EU began to proactively build external competition relations in the 1990s. Internal and external factors were involved in this development. Internally, EU competition policy substantially developed in the late 1980s and 1990s (Wilks 2010: 138). The European Commission became more active in the enforcement of existing competition rules, whereas the EU Council adopted the first merger regulation in 1989 (Regulation 4064/89). Additionally, the legal doctrines that underpin the EU's extraterritorial jurisdiction have developed through case law, including the Woodpulp judgement in 1988 (see Chapter 2). These internal policy developments were a precondition for the EU's external activism. Externally, the problem of international anticompetitive business practices has become more serious due to the increasing economic interdependence between the member states and their major trading partners. In the 1992 annual report on competition policy, the European Commission (1993: 15) stated that ' $[t]$ he globalisation of markets and the knock-on effects of certain anti-competitive behaviour outside the Community mean that policy must broaden to take account of the international dimension', and that the Commission would 'seek to encourage the application of similar policies by the Community's main trading partners' based on bilateral agreements and multilateral negotiations. This shows that the European Commission was already aware of the importance of international competition cooperation in the early 1990s.

Today, the EU's external competition policy pursues various political and economic interests, which concern law enforcement in individual cases and the international promotion of competition rules. Concerning law enforcement, the European Commission applies its competition rules beyond EU territory to tackle business practices that have adverse effects on the EU market. By exercising extraterritorial jurisdiction, the Commission aims to protect the economic interests of EU firms and consumers. At the same time, the Commission has a political interest in building bilateral competition relations to reduce the risk of interjurisdictional conflicts, which could be caused by the extraterritorial application of EU competition law. The EU's first competition cooperation agreement with the United States entered into force in 1995, but the agreement was insufficient to prevent a fundamental disagreement between them regarding the proposed merger of American firms (Boeing and McDonnell Douglas in 1997) (Damro 2001). Consequently, the European Commission became even more 
active in bilateral competition cooperation to reduce the risk of political conflict with major trading partners. Competition cooperation agreements are also intended to ensure the effective enforcement of law in international competition cases, such as cartels and mergers that affect multiple jurisdictions.

In addition to participating in law enforcement cooperation, the EU externally promotes competition rules to ensure that its stringent competition regulations do not put EU firms at a competitive disadvantage. Blauberger and Krämer (2013: 174) demonstrated this point in their research on the EU's state aid and public procurement policies. If the European Commission strictly enforces internal economic regulations, it would be criticised for disadvantaging EU firms in the global market. Conversely, if the Commission pursues lax enforcement for the interest of large EU firms, competition in the EU market would be distorted. To cope with this dilemma, the Commission attempts to export its economic regulations to other countries and international institutions to ensure a levelplaying field in the global market. The policy goal of the Commission is evident in various EU documents. For example, a staff working document attached to the European Commission's report on competition policy from 2019 states that the main goal of the EU's external competition policy is to advocate a global competition culture, promoting competition conditions to allow companies to compete on the merits of fair and equal terms across the world. The policy also seeks to 'reinforce the role of competition policy in international organisations' (European Commission 2020a: 40). These statements confirm the proposition that the EU aims to promote competition law and policy externally to alleviate the competition-competitiveness dilemma.

This policy goal is inextricably linked to the economic interests the EU pursues in a common commercial policy. This is evident in the European Commission's 2006 trade policy document Global Europe: Competing in the World ("the Global Europe trade strategy'). In this strategy, the European Commission (2006: 2) stated that the 'rejection of protectionism at home must be accompanied by activism in creating open markets and fair conditions for trade abroad' to strengthen the competitive position of the EU industry in the global economy. To achieve this objective, the EU needs 'a sharper focus on barriers to trade behind the border', such as the absence of competition and state aid rules in third countries. The absence of these rules would substitute tariffs and other tariff barriers and limit access to non-EU markets. Therefore, the EU 'has a strategic interest in developing international rules and cooperation on competition policies to ensure European firms do not suffer in third countries from unreasonable subsidisation of local companies or anti-competitive practices' (European Commission 2006: 7). Analysing the Global Europe trade strategy and other EU documents, Aydin (2012: 668-669) suggests that, through the international transfer of competition rules to other countries, the European Commission aims to achieve three main goals: to provide market access to EU firms around the world, to prevent anticompetitive conduct outside EU territory from negatively affecting the EU market, and to ensure the fair treatment of EU firms in other jurisdictions. 
While the European Commission aims to transfer its competition rules or their equivalents to other countries and international institutions, the effectiveness of this attempt depends on the means the Commission employs and the relationship between the EU and the target countries or institutions. One of the most effective mechanisms of the EU's external competition regulations is the transfer of its competition rules to neighbouring countries and candidate states for EU membership (Aydin 2012: 673-675). For example, through the establishment of the European Economic Area in 1994, the EU ensured that Iceland, Liechtenstein, and Norway enacted competition laws compatible with the EU's supranational competition law. This externalisation of EU rules in a hierarchical way has been relatively effective, although the problem of domestic implementation in the three countries remains (Bender 2019: 89-115). A series of EU enlargements after the end of the Cold War (1995, 2004, 2007, and 2013) also had a considerable impact on neighbouring countries. A majority of Central and Eastern European countries introduced competition laws compatible with those of the EU in the 1990s in pursuit of EU membership. Most of them experienced a transformation into a centrally planned economy, where state aid played an essential role, but there were no longer significant differences in compliance with EU state aid rules between new and old member states (Hölscher, Nulsch, and Stephan 2017). Additionally, research shows that accession to the EU improved the regulatory quality of competition policies in new member states (Böheim and Friesenbichler 2016). These pieces of evidence demonstrate the effectiveness of the EU's rule transfer based on conditionality.

That being said, there are two significant constraints on the EU's capability to transfer competition rules based on the enlargement policy. First, a credible prospect for membership is crucial for effective rule transfers to candidate states. Therefore, the capability would decrease as EU enlargement loses momentum (Aydin 2012: 675). Second, EU membership inherently has a geographic limit. For these reasons, the EU advocates multilateral competition cooperation within the framework of international organisations and global regulatory networks.

\subsection{The EU's failed attempt to establish the WTO competition law}

The EU advocated the creation of the WTO competition law from the mid1990 s to the early 2000s. This initiative can only be understood in a historical context. Multilateral competition cooperation is not a new phenomenon; it was discussed by the United Nations in the 1940s and began in the OECD in the 1960s. Additionally, UNCTAD promoted competition laws and policies while providing technical assistance to developing countries. These efforts have resulted in the incremental development of international competition rules. However, neither the OECD nor UNCTAD provides a comprehensive and enforceable legal framework for global competition regulations. 


\subsubsection{A patchwork of international competition rules}

The first attempt to create international competition rules was made in the 1940s. Fifty-three states signed the Havana Charter in 1948 for the establishment of the International Trade Organization (ITO) within the United Nations system. The ITO was expected to complement the Bretton Woods institutions, the International Monetary Fund and World Bank. The Havana Charter was an ambitious international agreement that covered not only traditional trade issues, such as tariffs and quotas, but also trade-related regulatory issues, including competition. It is widely believed that the signing of such an ambitious agreement was possible because the leaders of the signatory states still had fresh memories of the devastating damages caused by the Great Depression and protectionism during the interwar period. Chapter 5 of the Havana Charter was dedicated to competition rules, and Article 46 stated that each member state shall, in cooperation with the ITO, take appropriate measures to prevent 'business practices affecting international trade, which restrain competition, limit access to markets, or foster monopolistic control'. The article also provided an indicative list of restrictive business practices, such as price fixing and market sharing, while Article 50 specified the various obligations of the member states in this area. The ITO had the potential to become the first international organisation with binding competition rules.

However, the ITO did not come into existence because the Havana Charter's ratification process failed in the United States, one of the main advocates of the ITO. The United States Senate dismissed the charter twice without voting because of numerous requests for amendments from senators. Many of them were concerned about the loss of national sovereignty and opposed the establishment of international trade law associated with a dispute settlement mechanism (Wilcox 1949: 195-196). The opponents were also dissatisfied with the fact that the ITO adopted the 'one country, one vote' principle despite a huge discrepancy between the signatories in terms of economic, political, and military power (Wilcox 1949: 196-197). Subsequently, the issue of ratifying the charter was marginalised in the United States and other countries because the Cold War in Europe intensified in the late 1940s, and the Korean War broke out in June 1950 (Diebold 1952: 6). In parallel to the Havana Charter negotiation, multilateral trade negotiations among fewer countries took place, resulting in the General Agreement on Tariffs and Trade (GATT), which was signed in 1946 and came into effect in 1947. The GATT was originally designed as a temporary legal framework, whose mandate of trade liberalisation was supposed to be taken over by the ITO after its establishment. After the failure of the ITO plan, the GATT evolved into a major forum for multilateral trade negotiations. However, unlike the Havana Charter, the GATT had a rather limited scope, at least in its initial form, and lacked a competition chapter.

Since the 1960s, rising economic interdependence among developed countries has increased the importance of international policy coordination. Therefore, 
the OECD and UNCTAD incrementally developed soft law in this area to establish key principles and regulatory standards while facilitating law enforcement cooperation. The OECD Competition Committee facilitates the identification and dissemination of best practices in competition regulations. For example, the committee has issued numerous recommendations on international cooperation agreements and other substantive issues, such as cartel investigations and merger reviews. Furthermore, the committee has published numerous reports on the law enforcement records of selected countries and major policy developments for greater transparency. Technical and specialised discussions in the OECD have been particularly useful for developing countries, including the EU and its member states (Bender 2019: 141-160). UNCTAD also has a long history of competition law and policy promotion and offers technical assistance to developing countries. For example, in 1980, UNCTAD issued a resolution on competition policies, entitled the Set of Mutually Agreed Equitable Principles and Rules for Control of Restrictive Business Practices (United Nations Resolution 35/63, 5 December 1980). This resolution ('the Set') provided general principles and regulatory standards and served as a major reference point for developing countries, especially those that did not have competition laws and institutions yet. Today, the UNCTAD Intergovernmental Group of Experts on Competition Law and Policy regularly holds meetings and facilitates international policy discussions on salient issues. Overall, the OECD and UNCTAD have certainly contributed to experience sharing and benchmarking exercises among competition authorities on a multilateral basis.

However, there are significant constraints on the capacity of these organisations to develop international competition rules. First, the recommendations and reports of the OECD and UNCTAD on competition issues are non-binding. Second, UNCTAD focuses on the establishment of minimum regulatory standards and does not develop detailed rules that are essential for multilateral competition cooperation. This shortcoming is primarily due to UNCTAD's global membership and consensus-based decision-making processes. Third, the OECD has a legitimacy problem as a global rule-maker. Only developed countries can join the OECD, and their recommendations are mainly based on the experiences of these countries. Therefore, there is a wide belief among developing countries that the prescriptions offered by the OECD are biased or, at best, not universally applicable (Hollman and Kovacic 2011: 68-69).

Meanwhile, the number of jurisdictions with competition laws and institutions increased exponentially from the 1990s onward. While only 9 jurisdictions had competition laws at the end of the 1970s, the number increased to 23 by 1990 and reached 127 by October 2013 (OECD 2014: 26). This rapid and global diffusion resulted in considerable national diversity of competition laws in terms of goals, substantive and procedural rules, and institutional designs. A combination of this trend and growing economic interdependence increased the risk of interjurisdictional disagreements about competition law enforcement (OECD 2014: 39-46). 


\subsubsection{The WTO negotiation deadlock regarding competition rulemaking}

Against this background, the issue of trade and competition policy was raised at the WTO in the mid-1990s. At the WTO ministerial conference in Singapore in 1996, a group of developed countries, most notably the EU, officially proposed a set of new agenda points for the next round of multilateral negotiations, which was later named the Doha Round (or Doha Development Agenda). The proposal consisted of four agenda points ('the Singapore issues'): (1) trade and competition, (2) trade and investment, (3) transparency in government procurement, and (4) trade facilitation concerning customs rules. The proposal was derived from the proponents' strong concerns about behind-the-border regulatory issues as opposed to traditional on-the-border measures, such as tariffs and quotas. The Singapore issues were not entirely new in international economic law (Woolcock 2003: 255). As noted above, the OECD and UNCTAD incrementally developed regulatory norms and standards relating to competition. The annex of the WTO's General Agreement on Trade in Services (GATS), which came into force in 1995, touches upon the issue of trade and competition in the telecommunications and financial sectors. Therefore, the key question was whether WTO members should adopt a general framework agreement for each issue.

Since the EU was the main advocate of the Singapore issues, including competition, it is important to understand what exactly the EU's preference was, and how it was shaped. There are three key points from a theoretical perspective. First, the EU's proposal of international competition rule-making at the WTO can be regarded as an attempt to achieve 'vertical policy export' that refers to the creation of international law congruent with certain national or regional rules. As noted in Chapter 1, the EU often adopts other strategies, such as policy promotion, policy protection, and policy import (Müller, Kudrna, and Falkner 2014), but the EU pursued an ambitious policy export strategy in WTO negotiations on trade and competition. Second, this strategic choice of the EU is consistent with the argument that the EU seeks to promote competition rules externally to alleviate the competition-competitiveness dilemma. As the EU's competition rules were more developed than that of many WTO members, it attempted to create international competition laws similar to its own rules to enhance the international competitiveness of EU firms. Third, the EU's selection of the WTO as the primary multilateral forum indicated the EU's commitment to 'binding multilateralism', which refers to multilateral cooperation based on international law rather than non-binding agreements and political declarations (Damro 2006a: 209). The EU's commitment to binding multilateralism reflects its own experience in establishing supranational competition laws and policies for regional economic integration since the 1950s (Damro 2006a: 213-214). The EU's preference for the WTO is also consistent with the governance mode of its enlargement policy. The EU signs treaties with potential candidate states and conducts negotiations in a formal and highly institutionalised way. As the 
enlargement policy has been one of the most established methods for the EU to transfer its competition rules to neighbouring countries, there was no surprise that the EU preferred the WTO, one of the most institutionalised and judicialised international organisations. ${ }^{1}$

The former European Competition Commissioner Karel Van Miert and a group of experts played a key role in shaping the European Commission's concrete WTO policy regarding the issue of trade and competition. Van Miert was vice president of the European Commission (1993-1999), responsible for EU competition policy, and a strong advocate of competition rule-making at the WTO. He stressed the European Commission's commitment to multilateral economic cooperation in various speeches and initiated internal policy discussions on international competition relations. In 1994, he established the 'wise men group', which consisted of three external experts and six European Commission officials. $^{2}$ This group was mandated to design an institution of international competition rules, as well as to create effective implementation procedures once foreseen in the Havana Charter, while developing an approach based on the EU's experience in regional economic integration (European Commission 1995: 24). This reference to the Havana Charter and the EU's market integration experience indicated that the European Commission preferred multilateral rule-making in the WTO rather than cooperation based on soft law in other institutions.

After conducting extensive research and discussions, the wise men group submitted a final report to Van Miert in 1995. This report was entitled 'Competition policy in the new trade order: strengthening international cooperation and rules', and is commonly referred to as the Van Miert Report. The report explained the importance of international competition cooperation and made the following recommendations (European Commission 1995: 21-22):

1. Countries and groups of countries should be encouraged to introduce competition laws while ensuring effective law enforcement. Where necessary, developed countries, including the EU and its member states, should provide technical assistance to less experienced countries, especially developing countries.

2. On the one hand, bilateral cooperation between competition authorities should be maintained and strengthened. On the other hand, a plurilateral framework should be established, building on bilateral cooperation experiences between major competition agencies. Such a framework should acknowledge the basic principles of competition regulation, set up an effective dispute settlement mechanism, and have a limited geographical coverage at the beginning while keeping the membership potentially open to other countries.

3. The bilateral and plurilateral efforts noted above are complementary and reinforce each other. Therefore, they should be developed in parallel.

As the former deputy director-general of DG Competition Jean-François Pons (1999) noted in his speech, the report set ambitious long-term goals for the EU while also suggesting cautious smaller steps toward these goals. Regarding 
the short-term goals, the report strongly recommended a 'building block' approach consisting of two closely linked elements: a two-track approach and an incremental approach. The proposal of a two-track approach is evident in the second and third recommendations of the report mentioned above. Regarding the incremental approach, the report consistently used the term 'plurilateral' rather than 'multilateral' in order to emphasise the restrictive membership of the proposed international competition forum (European Commission 1995: 14-17, 21-22). As this word choice indicates, the wise men group considered that the idea of establishing binding competition rules in the WTO was premature and unrealistic. Referring explicitly to the WTO, the report stated that it would be 'counterproductive' to propose the creation of a multilateral legal framework, whose fate would fully depend on potential partners' willingness to participate (European Commission 1995: 22). Alternatively, the report suggested building a bridge between smaller regional blocks in which international cooperation in competition law enforcement was already active (e.g. the United States and Canada, Australia and New Zealand, and the EU itself). The group maintained that such efforts would be a significant step towards the creation of a plurilateral cooperation framework, possibly accommodating other OECD countries and interested parties.

However, the European Commission did not follow the experts' main advice. Instead of adopting the building block approach proposed in the report, the commission decided to pursue a more ambitious goal of establishing a WTO competition law. In other words, the European Commission ultimately made its own decision regarding the overall direction of the policy while following only a few recommendations that matched its own preferences (e.g. the reinforcement of existing bilateral cooperation). In retrospect, the European Commission was optimistic about the prospect of multilateral competition rule-making and failed to predict the profound opposition of numerous developing countries regarding this issue.

The process of the failure of WTO competition rule-making can be analytically divided into two phases: the first phase of initial exploratory discussions between 1996 and 1999 and the second phase of more substantial discussions between 1999 and 2004. The first phase began at the Singapore Ministerial Conference in 1996, which was the first major event of the WTO after its foundation in 1995. The Ministerial Conference is the highest decision-making body of the WTO and normally takes place every two years. At the conference in 1996, the EU proposed discussing Singapore issues in the next round of multilateral trade negotiations. Consequently, the issues of competition and investment were mentioned in paragraph 20 of the Singapore Ministerial Declaration adopted on 13 December 1996 (WTO 1996).

Regarding the issue of competition, the paragraph delivered three key messages. First, the WTO decided to establish a Working Group on the Interaction between Trade and Competition Policy. ${ }^{3}$ Second, the establishment of a working group would not presuppose the opening of official negotiations on trade and competition. This implied a disagreement among WTO members regarding the 
commencement of formal negotiations on competition rules. The lack of consensus among the members was reflected in the limited mandate of the working group. It was merely mandated to 'identify any areas that may merit further consideration in the WTO framework'. Third, the paragraph stated that an 'explicit consensus' would be required for the commencement of negotiations on competition matters. Put simply, all WTO members - around 130 at that time - were granted veto power regarding this issue. The explicit consensus is more demanding than the WTO's standard decision-making procedure, an implicit consensus, according to which proposals are approved without voting unless opposition is clearly expressed.

Furthermore, paragraph 20 stated that the progress of the working group would be reviewed by the General Council (i.e. an ambassador-level body of the WTO that supports the Ministerial Conference). Under the chairmanship of French economist Frédéric Jenny, the newly established working group conducted research on existing competition laws in various jurisdictions and explored the possibility of addressing trade-related competition issues within the WTO's legal framework. The working group submitted annual reports to the General Council from 1997 to 2003, based on discussions at regular meetings. The following analysis of the WTO's discussions on competition issues mainly draws on these reports and communications submitted by WTO members.

Between the Singapore Ministerial Conference in 1996 and the Doha Ministerial Conference in 2001, the working group focused on the study of three broad topics addressed by the chairperson in his memo, 'A Checklist of Issues Suggested for Study' (WTO 1997: 3). These topics were (1) the stocktaking and analysis of existing instruments, standards, and activities regarding trade and competition policy; (2) the relationship between the objectives, principles, concepts, scope, and instruments of trade and competition policy; and (3) the interaction between trade and competition policy.

As the working group held discussions on these substantial issues, it became clear that WTO members held widely divergent opinions (WTO 1999a: 10-12). On the eve of the 1999 Seattle Ministerial Conference, many states expressed their opinions in written communications. For example, the EU and its member states believed that 'the time has come for the WTO' to officially commence a multilateral negotiation on 'a basic framework of binding principles and rules of competition law and policy' (WTO 1999b: 1). Despite this optimistic view, only a few countries, such as Japan and the Republic of Korea (South Korea), supported the EU's call for official negotiations on binding competition rules and core principles (WTO 1999c, 1999d). The United States was highly critical of the EU's proposal (see below for details). Furthermore, a vast majority of WTO members strongly opposed the EU's proposal. As the communication from Cuba articulated, these opponents maintained that the exploratory discussions should continue in the working group without presupposing the commencement of official negotiations. They also argued that the WTO's priority should be the reinforcement of technical assistance programmes for developing and leastdeveloped countries rather than rule-making (WTO 1999e: 1-2). 
After the Seattle Ministerial Conference in 1999, the disagreement proved fundamental and irreconcilable. In the process of preparing a draft ministerial declaration for the 2001 Doha Ministerial Conference, some WTO members harshly criticised the EU's proposal. For example, the Commerce Secretary of India Prabir Sengupta delivered a speech at the General Council meeting in 2001 and stated that 'the manner in which the four Singapore issues are dealt with' was 'extremely disturbing'. India and many other countries repeatedly expressed serious concerns about the commencement of official negotiations on the competition issue 'without acquiring at least some minimum experience in implementing domestic competition law'. However, the EU and its key allies attempted to present the commencement of negotiations as the only option in the draft ministerial declaration. Sengupta commented that this tactic by the EU was 'surprising', 'upsetting', and unacceptable (WTO 2001a: 1).

The WTO adopted the Doha Ministerial Declaration on 14 November 2001 (WTO 2001b) and announced the launch of a post-Uruguay Round negotiation, the Doha Round. However, the fundamental disagreement between the WTO members on the Singapore issues remains unresolved. While the issue of competition was noted in paragraphs 23, 24, and 25 of the declaration, there was no substantial change. Paragraph 23 merely repeated the reservation made in the Singapore Ministerial Declaration. According to the paragraph, WTO members agreed that official negotiations on competition rules would occur 'after the Fifth Session of the Ministerial Conference [in Cancun in 2003] on the basis of a decision to be taken, by explicit consensus, at that Session on modalities of negotiations'. Therefore, the explicit consensus condition continued to be the biggest obstacle to the inclusion of competition issues in the WTO's negotiation agenda. Concerning the role of the working group, paragraph 25 of the declaration stated that further work in the working group should focus on clarifying the following issues:

1. Core principles, including transparency, non-discrimination, procedural fairness, and provisions on hardcore cartels

2. Modalities of voluntary cooperation

3. Support for progressive reinforcement of competition institutions in developing countries through capacity building

At the Cancun Ministerial Conference in Mexico in September 2003, the WTO members once again discussed whether the Singapore issues should be incorporated into the WTO's negotiation agenda. At this conference, a large majority of developing countries, including emerging economies such as India, collectively and strongly reaffirmed their opposition to the commencement of official negotiations on the Singapore issues, especially competition and investment. There were five main reasons why a large majority of developing countries profoundly disagreed with the commencement of negotiations on multilateral competition rules (Bhattacharjea 2006: 295-303; 
Papadopoulos 2010: 232-242; Woolcock 2003: 252-253). First, these countries believed that they were clearly disadvantaged in this policy area. They were concerned that developed countries with more experience in competition law enforcement might set international standards based on their own interests, taking advantage of less experienced countries in WTO trade disputes. Second, there was a wide belief among developing countries that strict competition laws would significantly constrain their national industrial policies and hinder their economic development. According to this viewpoint, industrial policies rather than competition policies should be prioritised, at least in the early stages of economic development, and that is exactly what many developed countries did in the past. Therefore, it was considered unfair to impose international competition rules on developing countries. Third, there was a problem with domestic implementation. Since many developing countries did not have any competition law at that time, it would have been difficult for them to ensure domestic legislation in accordance with new WTO rules on competition (i.e. the problem of de jure implementation). Furthermore, the enforcement of domestic competition laws was considered even harder and more costly for these countries because they had no experience in competition law enforcement and lacked regulatory capacities for it (i.e. the problem of de facto implementation). Fourth, the Working Group on the Interaction between Trade and Competition Policy did not address certain issues that were potentially of interest to many developing countries. These issues included export cartels, which were often conducted by large firms in developed countries and caused serious damage to the economies of developing countries. Fifth, developing countries had a general distrust of developed countries and expected them to make more concessions in other policy areas, especially trade in agriculture, before raising new trade issues such as competition.

Research shows that developing countries exerted more influence on the Doha Round than in the GATT negotiations because of successful coalition building. At the Doha Ministerial Conference in November 2001, 14 developing countries ${ }^{4}$ formed the 'Like-Minded Group' and opposed the inclusion of the Singapore issues in the negotiation agenda while stressing the importance of development issues (Narlikar and Tussie 2004: 949). The pressure from this group was the main reason why the explicit consensus procedure was codified in the Singapore and Doha Ministerial Declarations. A similar position was taken by the Core Group, which consisted of 12 developing countries. ${ }^{5}$ For example, the group issued a joint statement on 8 July 2003 and opposed the EU's communication that assumed the commencement of negotiations on the Singapore issues after the Cancun Ministerial Conference (WTO 2003a). Furthermore, to form a majority, these two groups cooperated with African, Caribbean, Pacific, and least developing countries (Narlikar and Tussie 2004: 950). All these groups behaved as a cohesive coalition concerning the Singapore issues under the leadership of emerging economies, most notably India, which belonged to the likeminded group and core group. 
The United States was also highly critical of the EU's proposal for the WTO competition law. The Assistant Attorney General of the Antitrust Division of the United States Department of Justice Joel Klein harshly criticised the EU at the OECD's conference on trade and competition on 30 June 1999. In his speech, he pointed out three shortcomings of the EU's proposal (Klein 1999: 42-43):

1. The EU's proposal does not articulate what practical problems the WTO faces, and how exactly new competition rules can solve them. The ambiguity of the proposal is evident in the fact that the EU has used numerous terms, such as common rules, common criteria, and principles, in its policy documents.

2. Even if problems are specified, it is difficult to create multilateral competition rules. There is no consensus among WTO members regarding the economic and legal principles of sound competition policies. Moreover, nearly half of the WTO members have no competition law, and many other members have extremely limited experience in competition law enforcement.

3. The WTO is not suitable for the enforcement of international competition law because the WTO has no experience in this policy area. If new competition rules are subjected to the WTO's dispute settlement mechanism, the dispute settlement body may make decisions for political reasons at the expense of economic rationality and legal neutrality.

For these reasons, Klein (1999: 43) concluded that the 'WTO antitrust rules would be useless, pernicious, or both, and would serve only to politicise the long-term future of international antitrust enforcement, including through the intrusion of trade disputes disguised as antitrust problems'. The American opposition to the EU's proposal is unsurprising because the WTO's competition law associated with a dispute settlement mechanism would have limited the American competition authorities' ability to apply its antitrust law extraterritorially. The United States preferred international enforcement cooperation based on non-binding and executive agreements (Fox 1997: 10-12). According to former Deputy Director-General of the European Commission's DG Competition Jean-François Pons, another concern of the United States was that negotiations on competition matters would reopen discussions over related and controversial issues, such as antidumping, which were of great importance for many developing countries (Pons 1999). For all these reasons, the United States preferred the status quo, where its competition authorities exerted considerable external regulatory influence.

After facing profound opposition from developing countries and the United States, the EU modified its negotiating strategy at the Cancun Ministerial Conference in September 2003. While the four Singapore issues were initially presented as a package, the EU suggested treating them separately in the negotiations (Woolcock 2003: 250). However, this suggestion confused the EU's key allies in the negotiation, most notably Japan and South Korea, and failed to gain 
support from the coalition of developing countries. Consequently, the fundamental disagreement among WTO members over the Singapore issues remained and contributed to the failure of the entire trade negotiation in Cancun. The Foreign Minister of Mexico Luis Ernesto Derbez, who chaired the conference, held extensive consultations with the delegates of numerous countries to facilitate the negotiation, but the WTO members did not reach a consensus (WTO 2003b). The five-day-long conference ended on 14 September 2003 without any substantial progress. As the Singapore issues triggered heated debates, the delegates could not spend sufficient time on discussions about other key issues, such as trade in agriculture and market access to goods. The delegates did not even have time to decide on the date and venue of the next ministerial conference.

Concerning the EU's internal politics, research suggests that the European Commission was not truly cohesive regarding WTO negotiations (Damro 2006b: 878; Papadopoulos 2010: 242-245). The European Commission's DG for Trade ('DG Trade') favoured competition rule-making at the WTO because it is the organisation where DG Trade plays the role of chief negotiator within the Commission. In other words, DG Trade had an organisational interest in connecting trade and competition policies in the WTO's negotiations. Conversely, DG Competition merely plays a supporting role in the EU's common commercial policy and does not have a strong organisational interest in the issue linkage. DG Competition preferred other institutions that focused on enforcement cooperation rather than rule-making because such institutions would improve the effectiveness of DG Competition's competition law enforcement without constraining its administrative discretion. It is difficult to determine how much this internal divide of the European Commission contributed to the failure of its efforts to create the WTO competition law. However, the analysis of the preferences of the two DGs helps to understand why the EU was simultaneously committed to two contrasting projects: rulemaking at the WTO and the establishment of a less institutionalised network of competition authorities, the ICN.

As the Singapore issues were one of the sticking points of the trade negotiations at the Cancun Ministerial Conference, the WTO members abandoned the commencement of official negotiations on competition, investment, and transparency in government procurement rules. Among the four Singapore issues, only trade facilitation became an agenda point for official negotiations. The WTO's General Council adopted a decision on 1 August 2004 and officially announced this modification of the negotiation agenda. At point $1(\mathrm{~g})$ of the decision, the General Council declared that the issues of competition, investment, and transparency in government procurement 'will not form part of the Work Program set out in the [Doha] Declaration and therefore no work toward negotiations on any of these issues will take place within the WTO during the Doha Round' (WTO 2004). Consequently, the Working Group on the Interaction between Trade and Competition Policy stopped its activities, and it remains inactive to the present. Furthermore, the Doha Round negotiation as a whole stagnated. There were a few developments; for example, the Bali Ministerial Conference 
in 2013 resulted in an agreement on several issues, such as trade in agriculture and trade facilitation (Dee 2013). However, the Doha Round is unlikely to be concluded. The refusal of the Trump administration to appoint new members of the WTO's Appellate Body worsened the situation, putting the WTO's dispute settlement mechanism in crisis since December 2019. Considering the challenges faced by the WTO, it is safe to conclude that its members do not have an incentive to raise the competition issue again, even if the current debates about WTO reforms progress under the new leadership of Director-General Ngozi Okonjo-Iweala.

The analytical framework of policy export (Müller et al. 2014) explained in Chapter 1 helps to conceptualise key factors in the failure of the EU's proposal for a WTO competition law. These factors are concerned with two key concepts proposed by the policy export literature: 'global constellation' and 'global setting'. There are three key factors in the global constellation. The first is the divergence of the preferences of the EU and United States (Botta 2014). The second is the profound opposition from the vast majority of developing countries. The third is their effective coalition building to block negotiations on competition issues. Regarding the global setting, a major factor that significantly constrained the EU's rule export capability was the decision-making procedure. As noted above, the Singapore and Doha ministerial declarations stated that an explicit consensus would be required for the commencement of official negotiations on competition rules. The explicit consensus procedure is much more demanding than the WTO's standard procedure of an implicit consensus and contributed to the negotiation deadlock. Overall, the WTO saga vividly illustrates the limitation of the EU's role as a global rule-maker in the area of competition law and policy.

\subsubsection{Japan-film and Mexico-telecoms: WTO disputes over trade and competition}

Among the trade disputes brought to the WTO (formerly, the GATT), two cases are particularly relevant to the issue of interaction between trade and competition. One is the case of Japan-Film (DS 44) between 1996 and 1998 and the other is the case of Mexico-Telecoms (DS204) between 2002 and 2004. They were selected as case studies because Japan-Film is the first case related to the intersection of trade and competition, whereas Mexico-Telecoms is the first case in which the WTO's panel ruled against a member state based on competition-related articles of the GATS.

Japan-Film was a trade dispute between the United States and Japan between 1996 and 1998. In this case, the United States explored the possibility of raising competition issues based on the WTO's existing trade law. In other words, this case can be regarded as an attempt by the United States to address competition matters despite a lack of comprehensive competition rules in the WTO law. A root cause of this dispute was a rivalry between the Japanese firm Fuji Film and the American firm Kodak. The following description of the case mainly draws 
from the WTO's panel report of $1998^{6}$ and a report by the OECD (2014: 16) on international competition issues.

After the Second World War, Japan's tariffs on imported consumer photographic film and paper allowed major Japanese firms, especially Fuji Film and Konica, to grow without full exposure to international competition. In 1967, as a result of the Kennedy Round (1964-1967) of the GATT trade negotiations, the Government of Japan began to gradually reduce tariffs on photographic film and paper for both black-and-white and colour photographs. This issue was further discussed during the Tokyo Round (1973-1979) and the Uruguay Round (1986-1994) of the GATT trade negotiations. Finally, in 1994, the government agreed to remove all remaining tariffs on these products. In 1995, Fuji and Konica together controlled around 85 percent of the domestic photographic material market, while two non-Japanese firms, Kodak (United States) and Agfa (Germany), had roughly 10 percent and 5 percent market share, respectively. Kodak regarded the removal of tariffs as a business opportunity and sought to increase its sales in the Japanese market using various promotional instruments such as rebates and discounts. Its market share increased temporarily but soon declined to the pre-1967 level. Subsequently, Kodak accused the Japanese photographic film and paper market of not being fully open to foreign firms because of Fuji's exclusive agreements with distributors ('vertical constraints'). Furthermore, Kodak argued that the Government of Japan violated the WTO law by supporting Fuji's restrictive practices. In May 1995, Kodak requested the Office of the United States Trade Representative to initiate legal action against Japan's allegedly exclusive governmental measures and competition-restricting business practices in the market. In response to Kodak's allegation, the Government of the United States officially requested the Japanese competition authority, JFTC, to investigate Fuji's business practices. However, the JFTC published a report on the case and concluded that Fuji's behaviour did not violate Japan's competition law. The United States termed this report 'a whitewash' and criticised it for being 'weak and woefully insufficient' (Hansen 1999: 1625). However, rather than imposing unilateral sanctions, the United States brought this case to the WTO, which established a dispute settlement panel for the case on 16 October 1996. As the WTO law only applies to the actions of governments, the case focused on the Government of Japan's public measures rather than Fuji's conduct.

The United States complained that Japan tolerated an exclusive distribution system in the photographic film and paper industry and that the system was based on vertical business agreements between producers, wholesalers, and retailers. The complaint concerned three legal and administrative measures taken by Japan's Ministry of Trade and Industry (MITI) and the JFTC-(1) distribution countermeasures; (2) the Large Stores Law of 1973; and (3) the Premiums Law and related measures. Regarding distribution countermeasures, the United States argued that the MITI's administrative guidelines, especially the 1970 Guidelines for Rationalisation of Transaction Terms, violated the WTO laws. While these measures were intended to streamline the distribution system in the photographic 
film and paper industry, they excluded imported goods from such traditional distribution channels. In particular, the MITI promoted the use of transaction terms such as discounts and rebates, and encouraged manufacturers, wholesalers, and retailers in the domestic photographic industry to share facilities such as joint warehouses and distribution routes. From the American perspective, this MITI policy resulted in the establishment of a single-brand distribution system that disadvantaged foreign firms (paragraphs 4.2 to 4.5). Regarding the Large Stores Law, the United Stated maintained that larger retailing stores tended to provide a wide range of products and tended to sell more imported photographic material than smaller retailers did. Therefore, by restricting the establishment of larger retail stores, the law hindered the growth of alternative distribution channels for imported photographic material (paragraph 4.14). Regarding the issue of restrictions on premiums, Japan's Premiums Law and other measures issued by the JFTC under the Japanese Antimonopoly Law restricted sales promotion activities such as discounts, gifts, coupons, and other advertising campaigns. According to the United States, these measures were intended to disadvantage foreign producers that tended to have ample financial and human resources as well as the ability to translate them into extensive and innovative commercial campaigns (paragraphs 4.16 and 4.18).

In response to these accusations, the Government of Japan made the following arguments. First, the MITI guidelines concerning distribution systems were intended to modernise Japan's distribution system and did not discriminate against imported goods (paragraph 4.6). Furthermore, the choice of a single-brand distribution system was a voluntary decision by individual firms and was not a result of government measures (paragraph 4.9). Second, there was no evidence of correlation between the size of stores and the likelihood of selling foreign products. Therefore, the United States' allegation regarding the Large Stores Law was flawed (paragraph 4.15). Third, the Premiums Law restricted only excessive commercial promotions and made no distinction between domestic and foreign products. Thus, the law did not discriminate against foreign firms (paragraph 4.17).

The panel's final report was adopted by the WTO's Dispute Settlement Body on 22 April 1998 and dismissed the central arguments of the United States. The report drew three conclusions (paragraphs 10.402-10.404). First, the United States did not demonstrate that Japan's distribution measures (the Large Stores Law and restrictions on premiums and commercial promotion) individually or collectively caused financial damage to American firms. Second, Japan's distribution measures regarding the photographic material market were origin-neutral and did not discriminate against imported products. Therefore, the measures did not breach the principle of national treatment under Article 3(4) of the GATT. Finally, the United States did not demonstrate that Japan breached its legal obligation of publishing its administrative rulings adequately and promptly under Article 10(1) of the GATT.

Thus, the Unite States' first attempt to address a competition-related trade dispute within the WTO's legal framework failed. This case showed how difficult 
it is for plaintiffs to prove the violation of the WTO law related to competition matters. The case also exhibited the difficulty for the WTO to settle such a case without specific competition rules (Hansen 1999: 1641). A competition lawyer, Dabbah (2010: 613), commented that the outcome in this case 'confirmed the unsuitability of the WTO' to solve such cases. Overall, the Japan-Film case raised an interesting issue of trade and exclusive vertical agreements, but it ironically clarified the WTO's limitations to settle competition-related trade disputes as well.

The second case, the Mexico-Telecoms case, was a United States-Mexico trade dispute between 2002 and 2004. In this case, the United States brought a complaint to the WTO and declared that the Government of Mexico violated its commitment under the WTO law by not initiating action against anticompetitive practices of a Mexican telecommunications service provider Telmex. The United States alleged that Telmex's conduct resulted in an illegal barrier for trade and disadvantaged foreign firms that provided telecommunications service from their home countries to Mexico. A WTO dispute settlement panel for this case was established on 17 April 2002. The following description of the case mainly draws from the panel's final report circulated on 2 April 2004 and adopted by Dispute Settlement Body on 1 June 2004. ${ }^{7}$

Telmex, a former state-owned company, is the largest fixed-line phone carrier in Mexico City. Although anticompetitive practices of Telmex, such as price fixing and market sharing, were widely recognised, Mexico's competition authority (Comisión Federal de Telecommunicaciones) did not take any action against the firm. The United States argued that such practices by Telmex and the authority's non-enforcement of Mexico's competition rules against the firm violated the GATS Annex on Telecommunications and the reference paper that prohibited anticompetitive practices of telecommunications firms with adverse effects on international trade.

The GATS is accompanied by annexes that provide sector-specific rules to which WTO member states could choose to subscribe. Mexico was among the 69 WTO member states that subscribed to the Annex on Telecommunications and its reference paper in $1997 .{ }^{8}$ The annex regulates government measures affecting the use of and the access to public telecommunications networks and services. This annex was agreed upon by the WTO members in recognition of 'the specificities of the telecommunications services sector' and 'its dual role as a distinct sector of economic activity and as the underlying transport means for other economic activities' (Section 1). The annex consists of seven parts ${ }^{9}$ and Section 5 obliges the WTO members to ensure that foreign firms can access existing networks of domestic incumbents. Section 5(a) states that the WTO members 'shall ensure that any service supplier of any other Member is accorded access to and use of public telecommunications transport networks and services on reasonable and non-discriminatory terms and conditions'. Furthermore, the reference paper that accompanies the annex specifies Mexico's legal obligations regarding the regulation of the telecommunications market. Section 1.1 of this reference paper states that '[a]ppropriate measures shall be maintained for the purpose of 
preventing suppliers who, alone or together, are a major supplier from engaging in or continuing anticompetitive practices'. Therefore, Mexico should have prohibited anticompetitive measures by major suppliers of telecommunications service. Section 1.2 provides an indicative list of illegal anticompetitive business practices. Furthermore, Section 2.2 grants foreign firms access to Mexico's telecommunications transport network ('interconnection') in a non-discriminatory manner. The complaint of the United States was concerned with these two sets of rules: the annex and the reference paper.

In the final report from 2 June 2004, the panel partially upheld the complaint of the United States and ruled that Mexico violated Section 5 of the Annex on Telecommunications and Sections 1.1 and 2.2 of the reference paper (paragraph 8.1). While the final report is lengthy and complex, three points are noteworthy. First, for the first time, the WTO's panel applied the competition-related provisions in the GATS in this case and addressed issues at the intersection of trade policies that dealt with public restraints and competition policies that mainly dealt with private restraints (Fox 2006: 291-292). Second, this case directly addressed the issue of non-enforcement of competition law as de facto trade barriers-an issue that was not fully addressed in the Japan-Film case. The Government of Mexico was held liable not for its actions but for failing to take appropriate steps against Telmex's practices. Third, the panel report had an impact-Mexico changed its policy to comply with the report's conclusions. In this sense, the case showed that the WTO was 'able to adopt competition-relevant measures and to engage in competition-related work with material results' (Dabbah 2010: 615-616). However, the impact of the panel's decision in the Mexico-Telecoms case should not be exaggerated. There was a problem of enforceability because the key terms used in the reference paper are not clearly defined (Goyder and Albors-Llorens 2009: 598-602). For example, the paper obliges governments to prevent 'major suppliers' of telecommunications services from engaging in or continuing anticompetitive practices, but there is no clear definition of 'major suppliers'. The relationship between this concept and the concept of dominance in competition laws needs to be clarified. More fundamentally, the annex and reference paper only provide sector-specific rules to which the WTO member states voluntarily subscribe. Overall, the Japan-Film and the Mexico-Telecoms cases are the most important trade disputes in the history of the WTO regarding the interaction between trade and competition policy. However, at the same time, these cases illustrate the limits of the WTO's ability to address competition issues within its current legal framework.

\subsection{The EU's evolving strategy for external competition relations}

The EU's institutional frameworks for external competition relations have diversified, especially after its proposal of the WTO competition law met with uncompromising resistance from a vast majority of the WTO member states. 
Regarding multilateral competition cooperation, the rise of the ICN has been amongst the biggest changes seen over the past two decades. Therefore, this section examines how this network emerged, what it does, and its implications for the EU as global rule-maker. Subsequently, the section provides an overview of various institutional frameworks used by the EU for bilateral and interregional cooperation and considers their usefulness for the EU's external transfer of its competition rules.

\subsubsection{The rise of the ICN and its implications}

The ICN is a global regulatory network of competition officials. It was established on 25 October 2001 by 16 competition authorities from 14 jurisdictions: Australia, Canada, the EU, France, Germany, Israel, Italy, Japan, South Korea, Mexico, South Africa, the United Kingdom, the United States, and Zambia (ICN 2020a). This network has expanded rapidly and brought together most competition authorities around the world. As of September 2020, the ICN comprises 140 competition authorities from 129 jurisdictions (ICN 2020b).

Research shows that the United States, rather than the EU, played a key role in the establishment of the ICN (Fox 2009; Janow and Rill 2011). In November 1997, the United States Department of Justice appointed an advisory group, the International Competition Policy Advisory Committee (ICPAC), to address international competition issues. The ICPAC was mandated to make policy recommendations on three key issues: multijurisdictional mergers, international cooperation between the United States and other countries in cartel enforcement, and the interaction of trade and competition policies (ICPAC 2000: 34). After extensive discussions and public hearings involving experts, other stakeholders, and competition officials of other countries, the ICPAC submitted a detailed final report to the Attorney General Janet Reno and the Assistant Attorney General for Antitrust Joel Klein of the United States Department of Justice in February 2000. The report called for multilateral efforts to "create a new venue where government officials, as well as private firms, non-governmental organizations and others can exchange ideas and work towards common solutions of competition law and policy problems' (emphasis in the original, ICPAC 2000: 300). This proposal provided a blueprint for establishing the ICN, which was initially called the Global Competition Initiative.

Furthermore, the report severely criticised the attempt to create the WTO competition law and stated that the ICPAC regarded 'efforts at developing a harmonised and comprehensive set of multilateral competition rules administered by a new supranational agency as not only unrealistic but also unwise' (ICPAC 2000: 271). According to the ICPAC, such efforts were 'politically unrealistic' because competition laws differed substantially across jurisdictions, making the use of a one-size-fits-all approach extremely difficult. Furthermore, the idea of establishing the WTO competition law was 'unwise' because agreements on general principles for competition regulations, such as the prohibition of hardcore 
cartels, would not reduce the risk of interjurisdictional conflicts that primarily derive from specific procedural and substantive differences between national and supranational competition laws. These criticisms reinforced the American competition authorities' sceptical view of the EU's proposal for the creation of the WTO competition law.

Assistant Attorney General Klein accepted this proposal and presented it the EC Merger Control 10th Anniversary Conference on 14 September 2000 (Klein 2000). The next day, the European Competition Commissioner Mario Monti welcomed the American initiative and called it a 'constructive step' toward 'multilateralism in competition matters beyond OECD’ (Monti 2000). In February 2001, the International Bar Association hosted a meeting of around 40 senior competition officials and experts in Ditchley Park, England, for further discussions on the Global Competition Initiative. The participants reached an agreement on three points (Janow and Rill 2011: 34). First, the new institution should be an informal network of competition policy officials with minimum budgetary implications. Second, membership should be inclusive and cover developed and developing countries, the private sector, and competition professionals. Third, emphasis should be placed on open discussions and the publication of non-binding best practices regarding competition issues, such as merger reviews and competition advocacy.

Consequently, the ICN was established on 25 October 2011 with all these characteristics regarding institutional structures, membership, activities, and the mode of governance. Regarding institutional structures, the ICN is much less institutionalised than international organisations such as the WTO and possesses neither a legal personality nor a permanent secretariat. In other words, the ICN has the typical characteristics of transgovernmental regulatory networks ${ }^{10}$ that have flexible and inexpensive structures and facilitate direct communication among agencies on technical issues (Djelic 2011). The ICN's activities are coordinated by the Steering Group consisting of 18 competition authorities, ${ }^{11}$ whereas five working groups on key themes (advocacy, agency effectiveness, cartels, mergers, and unilateral conduct) hold discussions on substantial issues. ${ }^{12}$ The Steering Group has no legal power to impose its decisions on the ICN members; thus, the ICN is a highly decentralised institution.

Regarding membership, three points are noteworthy. First, only competition authorities are eligible to become ICN members; other governmental bodies, such as the ministries of trade, cannot join this network. Regarding the role of the EU, the European Commission's DG Competition and national competition authorities of the EU member states are ICN members. Second, there are no other substantial criteria for ICN membership. It is open to both developed and developing countries. The memorandum on ICN's establishment and operation agreed upon by the founding members in 2011 merely states that '[m]embers need to be national or multinational competition agencies trusted with the enforcement of antitrust laws' (ICN 2001: 1). The ICN's operational framework adopted in 2012 added that all applications for membership must be approved 
by the Steering Group (ICN 2012: 1), but in reality, virtually all competition authorities from countries and regional organisations can join this network if they wish. Owing to this openness, the ICN's membership has grown exponentially over the past two decades. Third, the ICN 'welcomes the participation of antitrust experts from relevant consumer, business, and academic constituencies, as well as from the legal and economic professions' as non-governmental advisors (ICN 2012: 6). Such advisors can participate in most ICN events, except for intergovernmental meetings for internal decisions (ICN 2001: 2).

Regarding activities, the ICN is devoted to competition matters, as stated in its slogan - 'It is all competition, all the time' (ICN 2009: 1). In this respect, it significantly differs from the OECD and UNCTAD, which address competition issues in the broader context of economic and development cooperation. While the ICN conducts numerous activities (ICN 2011: 4-6), they fall within the following four categories:

1. Information sharing, experience sharing, and networking activities

2. The administration of various workshops - mostly conducted online-and annual conferences

3. Technical assistance mainly based on a series of free and open-access training videos ('ICN Training on Demand') on various aspects of competition law enforcement

4. The facilitation of international convergence of competition laws and policies

Regarding the mode of governance, the ICN seeks to facilitate the international convergence of competition laws and policies based on non-coercive measures such as recommended practices, case-handling and enforcement manuals, repots, templates on legislation, databases, and toolkits (ICN 2011: 1). Members conduct bottom-up benchmarking exercises to produce these measures, and the ICN disseminates them once they are approved by the members consensually at working groups and annual conferences. Thus, the ICN significantly differs from the WTO, the organisation that the EU initially preferred for multilateral competition rule-making (see Table 5.1).

While the ICN has certainly enhanced multilateral competition cooperation, the emergence of this regulatory network constrains the EU's policy transfer capability in three ways. First, as the ICN's main goal is to facilitate voluntary policy convergence based on bottom-up benchmarking exercises, it is impossible for its members to export their own rules to others through formal negotiations. Bargaining tactics such as issue linkage and side payments cannot be used in the context of the ICN, unlike typical trade negotiations. This means that the EU cannot leverage the attractiveness of its large market to set global regulatory standards in this policy area. Research shows a certain degree of international policy convergence based on the ICN's outputs, especially in the area of merger reviews (Aydin 2010; Coppola 2011), but such convergence is partial and occurs on a purely voluntary basis. 
TABLE 5.1 Main differences between the WTO and the ICN

\begin{tabular}{|c|c|c|}
\hline & $W T O$ & $I C N$ \\
\hline Institutional structures & $\begin{array}{l}\text { A highly institutionalised } \\
\text { and judicialised } \\
\text { international organisation }\end{array}$ & $\begin{array}{l}\text { A less institutionalised } \\
\text { transgovernmental } \\
\text { regulatory network with no } \\
\text { legality }\end{array}$ \\
\hline Membership & $\begin{array}{l}\text { Governments represented by } \\
\text { ministries of trade or } \\
\text { equivalent }\end{array}$ & $\begin{array}{l}\text { Competition authorities of } \\
\text { countries and regional } \\
\text { organisations }\end{array}$ \\
\hline $\begin{array}{l}\text { Focus of the discussions } \\
\text { on competition issues }\end{array}$ & $\begin{array}{l}\text { The establishment of legal } \\
\text { principles and norms } \\
\text { concerning trade and } \\
\text { competition policy } \\
\text { (abandoned in 2004) }\end{array}$ & $\begin{array}{l}\text { Substantive and procedural law } \\
\text { and internal regulations of } \\
\text { competition authorities }\end{array}$ \\
\hline Modes of governance & $\begin{array}{l}\text { Rule-making based on } \\
\text { formal negotiations and law } \\
\text { enforcement based on the } \\
\text { dispute settlement system }\end{array}$ & $\begin{array}{l}\text { The enhancement of voluntary } \\
\text { policy convergence based on } \\
\text { bottom-up benchmarking } \\
\text { exercises and the } \\
\text { dissemination of non-binding } \\
\text { measures }\end{array}$ \\
\hline
\end{tabular}

Source: Developed from Bode and Budzinski (2005: 10-15) and Fox (2009: 157-165).

Second, the EU has a strong presence in the ICN, but there are also several other influential regulators. They include competition authorities of developed countries, most notably from the United States, whose influence is evident from the fact that the American Bar Association's Section of Antitrust Law financially supported the ICN's on-demand training course, and several videos of the course contain presentations by American competition officials. ${ }^{13}$ Furthermore, partners from large Anglo-Saxon law firms are over-represented as non-governmental advisors, exhibiting a strong influence on this network (Djelic 2011: 82). Emerging economies such as Mexico, Brazil, and South Africa also play important roles in the ICN's Steering Group and working groups.

Third, as the ICN dedicates itself to competition issues and makes decisions consensually, it is difficult for the EU to raise new and controversial issues that are at the intersection of traditional competition policies and other policies. For example, the European Commission's DG Competition and some EU member states, such as Germany, proposed the issue of state aid as one of the future priorities of the ICN,${ }^{14}$ and this issue was mentioned in a key document 'ICN's Vision for its Second Decade' that reflected upon this network's experience during the first ten years and for the first time set out its long-term strategy (ICN 2011: 18). However, the proposal did not gain enough support from the other ICN members most likely because many of them had no competence and experience in state aid control and did not have a strong interest in raising this politically sensitive issue.

Overall, the ICN exemplifies a growing trend for multilateral competition cooperation based on soft law. The ICN does not seek to establish multilateral 
competition rules; it has always focused on voluntary policy convergence based on the dissemination of non-binding measures such as recommended practices. Hence, it is difficult for the EU to use the ICN to transfer its own competition rules to other jurisdictions in a hierarchical manner.

\subsubsection{Bilateral and interregional cooperation}

Regarding bilateral and interregional relations, the EU uses three main types of international agreements on competition cooperation: (1) competition cooperation agreements, (2) memoranda of understanding, and (3) FTAs with competition provisions. The EU also concluded general agreements containing competition rules with several countries, groups of countries, and regional organisations. These general agreements include Stabilisation and Association Agreements with Balkan states; the Cotonou Agreement with African, Caribbean, and Asian countries; and interregional agreements with the Caribbean Community and Central American Economic Integration (SIECA). The European Economic Area Agreement with Iceland, Liechtenstein, and Norway also covers competition issues. ${ }^{15}$ A comprehensive survey of all agreements concluded by the EU is beyond the scope of this book (see Demedts 2018; Papadopoulos 2010; Sekine 2020 for more details). Instead of discussing differences between individual agreements, this section explains the features of the three main types of agreements to identify systemic constraints on the EU's external competition policy.

The EU concluded competition cooperation agreements with the United States (1995 and 1998), Canada (1999), Japan (2003), South Korea (2009), and Switzerland (2014). This indicates that the EU tends to use this type of agreement for substantial cooperation with experienced competition authorities. These are voluntary agreements and do not have dispute settlement mechanisms. The agreements are intended to enhance law enforcement cooperation in individual cases between competition authorities while reducing the risk of interjurisdictional conflicts. Competition cooperation agreements, including those of the EU, usually include provisions on the following key issues ${ }^{16}$ :

1. Mutual notifications: Each party notifies the other party when its enforcement activities are likely to affect the interests of the other party.

2. Exchange of information: The parties exchange information about the cases under investigation. While legal constraints on the disclosure of information pose a major challenge to such exchanges, the 'second-generation' agreements, such as the one between the EU and Switzerland, allow the parties to exchange confidential business information under certain conditions. ${ }^{17}$

3. The principle of negative (or traditional) comity: A party considers the interests of the other party at all stages of its enforcement activities.

4. The principle of positive comity: A party may request another party to investigate alleged anticompetitive activities that taking place within the latter's jurisdiction but negatively affecting the referring party's market. ${ }^{18}$ 
5. Coordination in enforcement activities: For example, the parties coordinate the timing of their cartel investigations and remedies they impose on the proposed mergers.

While competition cooperation agreements are concluded between governments, the EU and many other jurisdictions also use agency-to-agency agreements ('memoranda of understanding') to build international competition relations (OECD 2016). DG Competition representing the EU concluded such an agreements with Brazil (2009), Russia (2011), China (2012), India (2013), and South Africa (2016). The DG also signed a similar agreement ('administrative agreement on cooperation') with Mexico in 2018. It is difficult to make a clear distinction between the EU's competition cooperation agreements and memoranda of understanding in terms of content because there are numerous overlaps between them (Demedts 2012: 238-243). The main difference between the two types of agreements is the EU's partner countries. On the one hand, the EU has concluded competition cooperation agreements with developed countries that have experienced competition authorities. On the other hand, the EU uses memoranda of understanding to establish channels for regular dialogues, trust building, and enforcement cooperation with emerging economies.

In contrast to the first and second types of agreements, FTAs allow the EU to place competition rules in the broader legal framework for international economic cooperation. ${ }^{19}$ While the content of competition provisions of the EU's FTAs varies significantly depending on its partners, these provisions have two common characteristics. First, compared with competition-dedicated agreements, a greater emphasis is placed on the establishment of principles rather than the facilitation of law enforcement in individual cases. For example, the EU's recent FTA with Japan that came into force in 2019 codified legal principles, such as the operational independence of competition authorities, nondiscrimination, procedural fairness, and transparency in Articles 4, 5, 6, and 7 of Chapter 11. Second, the EU has a general tendency to include not only competition rules on traditional issues (e.g. cartels, abuse of dominance, and mergers), but also relatively detailed state aid rules in its FTAs (Sekine 2020). As the European Commission's report on competition policy 2019 states, the EU seeks to include both sets of rules when negotiating FTAs with its partners (European Commission 2020b: 26). This linkage is almost impossible in bilateral competition-dedicated agreements because most national competition authorities outside the EU do not have competence in the area of state aid.

Overall, at both the multilateral and bilateral levels, the EU's external competition relations mainly rely on voluntary cooperation. This is evident from the EU's engagement in activities of the ICN, the OECD, and UNCTAD, and its extensive use of non-binding agreements for bilateral relations. An exception to this general trend is FTAs. On the one hand, they provide binding international competition rules, including state aid rules. On the other hand, competition provisions of the EU's FTAs tend to be more abstract than competition-dedicated bilateral 
agreements and merely confirm general principles that are already widely shared among several jurisdictions. Therefore, except for state aid rules, these provisions generally do not have enough added value. Apart from a few bilateral general agreements with (potential) candidate states and interregional agreements, such as the European Economic Area agreement, the EU does not possess any effective legal framework for the external transfer of its competition rules.

\section{Conclusion}

The EU has consistently promoted competition law and policy externally since the 1990s. A key goal of the EU's external competition policy is to address the competition-competitiveness dilemma, which derives from a combination of increasing competitiveness pressure in the global market and stringent competition regulations within the union. The EU initially pursued the international transfer of its own competition rules to other countries, mainly based on formal negotiations and legal agreements, especially in the context of its enlargement policy. Furthermore, the EU attempted to establish international competition rules within the WTO's legal framework. However, there is a growing trend of voluntary international competition cooperation and policy convergence based on soft law, especially after the collapse of the WTO negotiations on competition rule-making. Consequently, the EU's current external competition relations rely heavily on non-binding agreements and less institutionalised regulatory networks, such as the ICN, rather than rule-making bodies. Therefore, it is difficult for the EU to translate its economic resources and regulatory capacity into direct influence on other countries. While it uses FTAs to promote competition law and policy externally, the role of competition provisions in these agreements is usually limited to the establishment of general principles. These findings suggest that the competition-competitiveness dilemma remains unresolved, despite the EU's political commitment to the externalisation of its own competition rules through various channels.

\section{Notes}

1 A speech by the former European Competition Commissioner Karel Van Miert about competition policies in relation to Central and Eastern European countries is indicative of the link between the EU's enlargement policy and external competition policy. See Van Miert (1998: 2).

2 The external experts of this group were professors Frédéric Jenny, Ulrich Immenga, and Ernst-Ulrich Petersmann. The selected European Commission officials were Claus-Dieter Ehlermann and Jean François Pons of DG IV (competition policy), Roderick Abbott of DG I (external relations), François Lamoureux and Jean-François Marchipont of DG III (industrial policy), and Alexis Jacquemin of the Forward Studies Unit.

3 Regarding the other Singapore issues, the Working Group on Trade and Investment and the Working Group on Transparency in Public Procurement were established soon after the Singapore ministerial conference. At the conference, it was decided that the WTO's existing institution, the Committee on Trade in Goods, would be 
responsible for the issue of trade facilitation, which was less controversial than the other Singapore issues.

4 The Like-Minded Group consisted of Cuba, the Dominican Republic, Egypt, Honduras, India, Indonesia, Kenya, Malaysia, Pakistan, Sri Lanka, Tanzania, Uganda, and Zimbabwe. Jamaica and Mauritius participated as observers.

5 The Core Group initially consisted of 12 countries: Bangladesh, Cuba, Egypt, India, Indonesia, Kenya, Malaysia, Nigeria, Pakistan, Venezuela, Zambia, and Zimbabwe.

6 WTO, Japan-Film (Japan-Measures affecting consumer Photographic Film and Paper), Report of the Final, WT/DS44/R, 31 March 1998.

7 WTO, Mexico-Telecoms (Mexico-Measures Affecting Telecommunications Services), Report of the Final, WT/DS204/R, 2 April 2004.

8 Fox (2006) provides a useful account of the establishment of these annexes.

9 The annex consists of seven sections: objectives, scope, definitions, transparency, access to and use of public telecommunications transport networks and services, technical cooperation, and relations with international organisations and agreements.

10 For general discussions on trans-governmental regulatory networks, see Abbott, Kauffmann, and Lee (2018) and Slaughter (2004).

11 As of 31 March 2021, heads of competition authorities of the following countries comprise the ICN's Steering Group: Germany (Chair), Mexico, Brazil, Colombia, Russia, South Africa, Canada, the United Kingdom, the United States (the Department of Justice and the Federal Trade Commission), France, Singapore, Belgium, Portugal, Hungary, South Korea, Italy, Australia, Japan, and Turkey.

12 For more details about the Steering Group and working groups, see ICN (2012).

13 The ICN website, 'ICN Training on Demand': https://www.internationalcompetitionnetwork.org/training/ [accessed: 31 March 2021].

14 This point is based on an interview with two officials of DG Competition in Brussels on 12 June 2014.

15 The latest list of the EU's international agreements containing competition rules can be found at https://ec.europa.eu/competition/international/bilateral/index.html.

16 See, for example, Articles 2-6, and 8 of the EU-United States agreement (1995). $\mathrm{OECD} / \mathrm{ICN}$ (2021) provides a general and detailed discussion on international competition cooperation.

17 See Articles 7-10 of the EU-Switzerland agreement (2014).

18 For more details about the meaning of negative and positive comities, see OCED (2014: 13).

19 For a general discussion on competition provisions of FTAs around the world, see OECD (2019).

\section{References}

Abbott, K. W., Kauffmann, C. and Lee, J. R. (2018). The Contribution of Transgovernmental Networks of Regulators to International Regulatory Cooperation. OECD Regulatory Policy Working Papers, 10, pp. 1-91.

Aydin, U. (2010). The International Competition Network: Cooperation and Convergence in Competition Law. Competition Journal, 11(3), pp. 51-78.

Aydin, U. (2012). Promoting Competition: European Union and the Global Competition Order. Journal of European Integration, 34(6), pp. 663-681.

Bender, B. (2019). Externalizing EU Competition Policy: Implementation and Coordination Realities in Non-EU Countries and Global Forums. Doctoral dissertation, University of Amsterdam.

Bhattacharjea, A. (2006). The Case for a Multilateral Agreement on Competition Policy: A Developing Country Perspective. Journal of International Economic Law, 9(2), pp. 293-323. 
Blauberger, M. and Krämer, R. U. (2013). European Competition vs. Global Competitiveness: Transferring EU Rules on State Aid and Public Procurement Beyond Europe. Journal of Industry, Competition and Trade, 13(1), pp. 171-186.

Bode, M. and Budzinski, O. (2005) Competing Ways Towards International Antitrust: the WTO Versus the ICN. Marburg Papers on Economics, 03-2005, pp. 1-31.

Böheim, M. H. and Friesenbichler, K. S. (2016). Exporting the Competition Policy Regime of the European Union: Success or Failure? Empirical Evidence for Acceding Countries. Journal of Common Market Studies, 54(3), pp. 569-582.

Botta, M. (2014). Competition Policy: The EU and Global Networks. In: G. Falkner and P. Müller (eds), EU Policies in a Global Perspective: Shaping or Taking International Regimes? Abingdon: Routledge, pp. 76-92.

Coppola, M. (2011). One Network's Effect: The Rise and Future of the ICN. Concurrences, 3, pp. 222-229.

Dabbah, M. M. (2010). International and Comparative Competition Law. Cambridge: Cambridge University Press.

Damro, C. (2001). Building an International Identity: the EU and Extraterritorial Competition Policy. Journal of European Public Policy, 8(2), pp. 208-226.

Damro, C. (2006a). Institutions, Ideas and a Leadership Gap: The EU's Role in Multilateral Competition Policy. In: O. Elgström and M. Smith (eds), The European Union's Roles in International Politics: Concepts and Analysis. Abingdon: Routledge, pp. 208-224.

Damro, C. (2006b). The New Trade Politics and EU Competition Policy: Shopping for Convergence and Cooperation. Journal of European Public Policy, 13(6), pp. 867-886.

Dee, M. (2013). The 9th WTO Ministerial Conference: A Victory for the WTO but What Next? GR:EEN Working Paper Series, 45, pp. 1-24.

Demedts, V. (2012). International Competition Law Enforcement: Different Means, One Goal? Competition Law Review, 8(3), pp. 223-253.

Demedts, V. (2018). The Future of International Competition Law Enforcement: An Assessment of the EU's Cooperation Efforts. Boston: Brill.

Diebold, W. (1952). The End of the ITO. Essays in International Finance: No. 16, Princeton, NJ: Princeton University, pp. 1-37.

Djelic, M. L. (2011). International Competition Network. In: T. Hale and S. Held (eds), Handbook of Transnational Governance: Institutions and Innovations. Cambridge: Polity, pp. 80-88.

European Commission (1993). XXIInd Report on Competition Policy 1992. Luxembourg: Office for Official Publications of the European Communities.

European Commission (1995). Competition Policy in the New Trade Order: Strengthening International Cooperation and Rules, COM(96)359 final.

European Commission (2006). Global Europe: Competing in the World: A Contribution to the EU's Growth and Jobs Strategy, COM(2006)567 final.

European Commission (2020a). Report on Competition Policy 2019: Commission Staff Working Document, SWD(2020)126 final.

European Commission (2020b). Report on Competition Policy 2019, COM(2020)302 final.

Fox, E. M. (1997). Toward World Antitrust and Market Access. American Journal of International Law, 91(1), pp. 1-25.

Fox, E. M. (2006). The WTO's First Antitrust Case-Mexican Telecom: A Sleeping Victory for Trade and Competition. Journal of International Economic Law, 9(2), pp. 271-292.

Goyder, J. and Albors-Llorens, A. (2009). Goyder's EU Competition Law. 5th ed. New York: Oxford University Press. 
Hansen, P. I. (1999). Antitrust in the Global Market: Rethinking Reasonable Expectations. Southern California Law Review, 72(6), pp. 1601-1650.

Hollman, H. M. and Kovacic, W. E. (2011). The International Competition Network: Its Past, Current and Future Role. In: P. Lugard (ed), The International Competition Network at Ten: Origins, Accomplishments and Aspirations. Cambridge: Intersentia, pp. 51-91.

Hölscher, J., Nulsch, N. and Stephan, J. (2017). State Aid in the New EU Member States. Journal of Common Market Studies, 55(4), pp. 779-797.

Fox, E. M. (2009). Linked-In: Antitrust and the Virtues of a Virtual Network. International Lawyer, 43(1), pp. 151-174.

ICN. (2001). Memorandum on the Establishment and Operation of the International Competition Network [Online]. Available at: https://www. internationalcompetitionnetwork.org/wp-content/uploads/2019/07/ICNMemo_ on_Establishment.pdf [accessed: 31 March 2021].

ICN. (2009). ICN Factsheet and Key Messages [Online]. Available at: https://www. internationalcompetitionnetwork.org/wp-content/uploads/2018/09/Factsheet2009. pdf [accessed: 31 March 2021].

ICN. (2011). The ICN's Visions for its Second Decade [Online]. Available at: https:// www.internationalcompetitionnetwork.org/wp-content/uploads/2018/07/ ICN2dDecade2011.pdf [accessed: 31 March 2021].

ICN. (2012). International Competition Network: Operational Framework [Online]. Available at: https://www.internationalcompetitionnetwork.org/wp-content/uploads/ 2018/07/ICNOperationalFramework.pdf [accessed: 31 March 2021].

ICN. (2020a). About [Online]. Available at: https://www. internationalcompetitionnetwork.org/about/ [accessed: 31 March 2021].

ICN. (2020b). News Release: ICN 2020 Annual Conference [Online]. Available at: https:// www.internationalcompetitionnetwork.org/featured/news-release-icn-2020annual-conference/ [accessed: 31 March 2021].

ICPAC. (2000). Final Report. Washington DC: US Government Printing Office.

Janow, M. E. and Rill, J. F. (2011). The Origins of the ICN. In: P. Lugard (ed), The International Competition Network at Ten: Origins, Accomplishments and Aspirations. Cambridge: Intersentia, pp. 21-37.

Klein, J. I. (1999). A Reality Check on Antitrust Rules in the World Trade Organization, and a Practical Way Forward on International Antitrust: Keynote Address. In: Trade and Competition Policies: Exploring the Ways Forward. Paris: OECD Publications, pp. 37-45.

Klein, J. L. (2000). Time for a Global Competition Initiative? Speech at the EC Merger Control 10th Anniversary Conference, Brussels, 14 September [Online]. Available at: https://www.justice.gov/atr/speech/time-global-competition-initiative [accessed: 31 March 2021].

Monti, M. (2000). The Main Challenges for a New Decade of EC Merger Control. Speech at the EC Merger Control 10th Anniversary Conference, Brussels, 15 September [Online]. Available at: https://ec.europa.eu/commission/presscorner/ detail/en/SPEECH_00_311 [accessed: 31 March 2021].

Müller, P., Kudrna, Z. and Falkner, G. (2014). EU-Global Interactions: Policy Export, Import, Promotion and Protection. Journal of European Public Policy, 21(8), pp. 1102-1119.

Narlikar, A. and Tussie, D. (2004). The G20 at the Cancun Ministerial: Developing Countries and Their Evolving Coalitions in the WTO. The World Economy, 27(7), pp. 947-966. 
OECD. (2014). Challenges of International Cooperation in Competition Law Enforcement [Online]. Available at: https://www.oecd.org/daf/competition/ Challenges-Competition-Internat-Coop-2014.pdf [accessed: 31 March 2021].

OECD. (2016). Inventory of Provisions in Inter-agency Cooperation Agreements (MoUs), DAF/COMP/WP3(2016)1/REV2.

OECD. (2019). Competition Policy within the Context of Free Trade Agreements, DAF/COMP/GF(2019)5.

OECD/ICN. (2021). OECD/ICN Report on International Cooperation in Competition Enforcement [Online]. Available at: http://www.oecd.org/competition/oecd-icnreport-on-international-cooperation-in-competition-enforcement-2021.htm [accessed: 31 March 2021].

Papadopoulos, A. S. (2010). The International Dimension of EU Competition Law and Policy. Cambridge: Cambridge University Press.

Pons, J. F. (1999). International Cooperation in Competition Matters: Where are We After Four Years After the Van Miert Report? Speech, Zurich, 9 July [Online]. Available at: https://ec.europa.eu/competition/speeches/text/sp1999_015_en.html [accessed: 31 March 2021].

Sekine, T. (2020). Possibility of Developing and Expanding the Regulation of Subsidies Through Free Trade Agreements (FTAs): Analysis Focusing on a Trend in FTAs Concluded by the EU. Public Policy Review, 16(5), pp. 1-33.

Slaughter, A. M. (2004). A New World Order. Princeton: Princeton University Press.

Van Miert, K. (1998). Competition Policy in Relation to the Central and Eastern European Countries: Achievements and Challenges. Competition Policy Newsletter, 2, pp. 1-10.

Wilcox, C. (1949). A Charter for World Trade. New York: Macmillan.

Wilks, S. (2010). Competition Policy: Towards an Economic Constitution? In: H. Wallace, M. A. Pollack and A. R. Young (eds), Policy-Making in the European Union, 6th ed. Oxford: Oxford University Press, pp. 133-155.

Woolcock, S. (2003). The Singapore Issues in Cancún: A Failed Negotiation Ploy or a Litmus Test for Global Governance. Intereconomics, 38(5), pp. 249-255.

WTO. (1996). Singapore Ministerial Declaration, WT/MIN(96)/DEC.

WTO. (1997). Report (1997) of the Working Group on the Interaction between Trade and Competition Policy to the General Council, WT/WGTCP/1.

WTO. (1999a). Report (1999) of the Working Group on the Interaction between Trade and Competition Policy to the General Council, WT/WGTCP/3.

WTO. (1999b). Communication from the European Communities, WT/GC/W/191.

WTO. (1999c). Communication from Japan, WT/GC/W/308.

WTO. (1999d). Communication from Korea, WT/GC/W/298.

WTO. (1999e). Communication from Cuba, WT/GC/W/389.

WTO. (2001a). Communication from India, WT/GC/W/459.

WTO. (2001b). Doha Ministerial Declaration, WT/MIN(01)/DEC/1.

WTO. (2003a). Comments on the EC Communication (WT/GC/W/491) on the Modalities for the Singapore Issues, WT/GC/W/501.

WTO. (2003b). Day 5: Conference Ends Without Consensus [Online]. Available at: https://www.wto.org/english/thewto_e/minist_e/min03_e/min03_14sept_e.htm [accessed: 31 March 2021].

WTO. (2004). Decision Adopted by the General Council on 1 August 2004, WT/L/579. 


\section{6}

\section{THE EU}

\section{Stuck between competition and competitiveness}

This book started by arguing that the EU struggles with a difficult choice between promoting competition for regional economic integration and enhancing the international competitiveness of EU firms. In other words, the EU is currently facing a competition-competitiveness dilemma. Against this background, the book examined how exactly the EU is coping with this dilemma internally and externally. To answer this broad question on a step-by-step basis, the book raised three more specific research questions: (1) Does EU competition policy seek to create or strengthen dominant EU firms at the expense of promoting competition? (2) Does this policy discriminate against non-EU firms for industrial policy purposes? (3) How effective is the EU's attempt to alleviate the dilemma by creating international rules congruent with its own law? Chapter 1 provided a theoretical framework for this research. Chapter 2 explained the institutional basis for the EU's internal and external competition regulations. Chapters 3, 4 , and 5 conducted empirical research to answer the three research questions, respectively.

This chapter first summarises the key findings of each chapter and draws conclusions. Theoretical and empirical contributions of this book to the existing literature are also explained. Section 2 provides further reflections on the internal and external implications of the EU's stringent competition policy. Section 3 suggests three important and underexplored topics for future research: the longterm regulatory influence of the EU on non-EU firms, the ongoing review of EU competition rules, and the impact of the current coronavirus (COVID-19) pandemic on EU competition policy. 


\subsection{Empirical and theoretical contributions to the literature}

To place this research in context, Chapter 1 sketched current political debates over EU competition policy while explaining the intended contributions of this book to the literature on this policy. Furthermore, the chapter reviewed the literature on regulatory states and, based on this insight, made two propositions. First, it was proposed that the EU's supranational institutional setting ensures a stringent competition policy that is non-discriminatory and comparatively strict. Two more specific hypotheses were generated based on this proposal: (1) Supranationally institutionalised competition policies, such as that of the EU, prioritise the promotion of market competition over the enhancement of local firms' international competitiveness. (2) The supranational institutional setting hinders the EU's discriminatory use of its competition policy against non-EU firms. Second, it was proposed that the EU promotes competition law and policy externally to address the competition-competitiveness dilemma.

Chapter 2 established three points to provide a basis for further analyses in subsequent chapters. First, the European Commission possesses strong investigative and decision-making powers in EU competition policy, although its law enforcement system has been decentralised to a certain extent since modernisation reforms in 2004. Second, the four main areas of EU competition policy (i.e. restrictive practices, abuse of dominance, mergers, and state aid) developed at different speeds and face different challenges; however, the European Commission is now equipped with strong legal measures, especially financial penalties, in all areas of this policy. Third, while EU competition policy originally focused on its internal aspects, a legal basis for extraterritorial jurisdiction has incrementally developed through case law. Furthermore, the European Commission started to proactively build external competition relations in the 1990s through bilateral and multilateral channels.

Chapter 3 focused on the internal aspects of EU competition policy and examined whether it prioritises the promotion of market competition over the enhancement of local firms' international competitiveness, as hypothesised in Chapter 1. The literature shows that merger and state aid policies are a frequent source of disagreement between national and supranational competition authorities regarding the balance between market competition and industrial competitiveness. To ascertain which goal takes precedence in practice, the chapter first analysed selected merger cases in three politically sensitive sectors: motor vehicles, rail transport, and energy. The disallowance of the proposed Volvo/Scania and Siemens/Alstom mergers in 2000 and 2019 suggests that the European Commission prioritises the maintenance of market competition rather than the creation of larger EU firms. This does not necessarily mean that the European Commission is more hostile than member states to all types of mergers. As the E.ON/Endesa case (2006) illustrates, the Commission generally promotes cross-border mergers and confronts member states that try to protect their large domestic firms from foreign capital. The analysis of state aid control offered 
more nuanced insights. After the global financial crisis of 2007-2008, EU state aid rules were temporarily relaxed. Subsequently, the European Commission once again began to ensure strict law enforcement and proactively tackled the issue of tax rulings. However, the current outbreak of COVID-19 posed one of the biggest challenges to EU state aid control. Further research is necessary to thoroughly evaluate the impact of the economic crisis caused by the pandemic.

Chapter 4 investigated whether EU competition policy discriminates against non-EU firms through an analysis of quantitative data and controversial cases that involved non-EU firms from the 1990s to the 2010s. The analysis focused on three policy areas: cartels, abuse of dominance, and mergers. The case studies included the vitamins cartel, the TV and computer monitor tubes cartel, Microsoft (interoperability and tying), Google (online shopping, Android mobile devices, and online advertising), and the proposed GE/Honeywell merger. To provide balanced arguments, the chapter engaged with discussions about EU competition policy in Japan and the United States. While the European Commission's competition decisions are sometimes criticised for their lack of rigorous economic and legal assessments, the analysis in Chapter 4 showed that there is no clear evidence of systematic discrimination against non-EU firms. The European Commission is tough on all firms, regardless of their country of origin. This is most likely because, as suggested in Chapter 1, the main goal of EU competition policy is the maintenance of market competition rather than the direct creation and strengthening of dominant EU firms.

Chapter 5 analysed the EU's external competition relations. The evidence showed that, instead of discriminating against non-EU firms, the EU attempts to address the competition-competitiveness dilemma by externally promoting competition law and policy. The EU initially used formal negotiations and legal agreements as the main method of international transfer of its own competition rules to other countries, especially in the context of its enlargement policy. Furthermore, the EU took an initiative with the WTO to create binding international competition rules. However, the EU's primary focus shifted to international cooperation and voluntary policy convergence through soft law, especially after the collapse of WTO negotiations on competition rule-making. Since the EU's current external competition relations rely heavily on regulatory networks such as the ICN rather than rule-making bodies, it is difficult for the EU to translate its economic resources and regulatory capacity into direct influence on other countries. While the EU uses FTAs to promote competition law and policy externally, the role of competition provisions in these agreements is generally limited to the establishment of general principles. These findings suggest that the EU's capability to transfer its own competition rules to other jurisdictions and international institutions is significantly constrained by systemic factors, such as the WTO negotiation deadlock, a growing trend for voluntary competition cooperation based on soft law, and competition with the United States.

In conclusion, the findings of this study suggest two key points. First, the supranational institutional structure, which was originally designed for internal 
competition regulations, significantly constrains both internal and external aspects of EU competition policy. This inside-out perspective is the key to the better understanding of the EU's distinctive supranational competition regulation and its external implications. In theory, the EU could use its competition rules in a neo-mercantilist manner to maximise its economic welfare. EU competition policy could prioritise the creation and strengthening of dominant EU firms and the promotion of their international competitiveness. However, the evidence of this book shows that the EU does not adopt this type of competition policy (a strategic competition policy). The maintenance of a level-playing field in the single market remains to be the EU's priority, despite the emphasis on the promotion of international competitiveness in its various political statements and policy documents, such as the Europe 2020 strategy for economic growth (European Commission 2010). This implies that EU competition policy is still essentially an internal economic policy rather than a foreign economic policy.

Second, the EU's regulatory influence relating to competition is asymmetric. The European Commission is largely resistant to internal and external political pressures in the review of competition cases and exerts enormous regulatory influence on individual firms and other undertakings. This regulatory influence is underpinned by the attractiveness of the EU market, the European Commission's considerable regulatory capacity, and the legal basis for extraterritorial jurisdiction. Case studies presented in Chapters 3, 4, and 5 of this book confirmed these points. Conversely, the EU's capability to set global competition rules and institutions is significantly constrained by various systemic factors. This is particularly evident in the failure of the EU's proposal of creating a WTO competition law and the rise of the ICN led by the United States. These findings suggest that the EU is still facing the competition-competitiveness dilemma, despite the EU's political commitment to the externalisation of its own competition rules through various channels.

Overall, this book has theoretically and empirically contributed to the literature on EU competition policy. Theoretically, the book developed an original concept of stringent competition policy that prioritises the maintenance of market competition rather than the enhancement of domestic firms' international competitiveness. Furthermore, the book demonstrated the usefulness of this concept in explaining the internal and external dimensions of EU competition policy as well as their interaction. Empirically, the book examined the underexplored issue of discrimination against non-EU firms using numerous sources of information. To provide a balanced argument, Chapter 4 used not only the EU's publications and database but also the publications of the Government of the United States, the Government of Japan, and a Japanese business association (the JBCE) among others. News articles were also used extensively for case studies. While the existing literature tends to focus on transatlantic relations in terms of case selection, this book analysed high-profile cases involving Japanese and South Korean firms as well as American and European firms.

It should be noted that this book proposed the notion of stringent competition policy as a heuristic analytical device rather than a normative benchmark. It is 
a notion that is useful to explain supranationally institutionalised competition policies, such as that of the EU. One may argue that strategic competition policies, which prioritise the promotion of international competitiveness, are more flexible and useful as foreign economic policies. The choice between these two types of competition policies depends on governments' goals and institutional designs for policy-making. Therefore, it is hard to state which type is generally superior to the other.

The supranational institutional setting that underpins the EU's stringent competition policy is a distinctive feature of the EU. Although other jurisdictions may also pursue a stringent competition policy for different reasons, the concept of strategic competition policy would be more useful to explain the policies of some governments. This concept suggests that governments aggressively apply their competition rules to foreign firms to complement their trade policies or, alternatively, pursue the lax enforcement of their competition rules for industrial development, especially in the early stages of economic development. In any case, it would be interesting to conduct further research on the interaction between competition, trade, and industrial policies of major economies from a comparative perspective. ${ }^{1}$ Different countries and regional organisations strike the balance between competition and competitiveness differently. Stringent competition policies could be the exception rather than the rule.

\subsection{Further reflections on the EU's stringent competition policy}

It is worth addressing two further questions to thoroughly evaluate the implications of this research. First, why does the European Commission firmly commit itself to a stringent competition policy? Second, does the EU's stringent competition policy constitute de facto barriers to trade with non-EU countries?

Regarding the first question, the European Commission's approach to competition regulations can be explained through the analysis of institutions, interests, and ideas. ${ }^{2}$ While all of these factors have been analysed in this book, a more explicit explanation would be useful to lay the foundation for future research. The significance of institutional structures in the formation EU competition policy has been particularly stressed in this book. As the literature on regulatory states suggests, the European Commission's relative independence from national and sectoral interests is primarily attributable to its nature as a supranational and non-majoritarian institution. Members of the European Commission (i.e. the commissioners and officials of DGs) are not directly elected by EU citizens. Therefore, they do not pursue short-term interests for elections. This allows the European Commission to play the role of independent referee who ensures comparatively strict and nationality-blind regulations. This would be extremely difficult, if not impossible, without an established supranational institutional basis. From the perspective of interests, there is little incentive for the European Commission to favour particular member states and firms in competition cases. 
As the European Commission consists of non-elected bureaucrats, its legitimacy heavily relies on its credibility as an independent regulator as well as its accountability and problem-solving capacities (Majone 1999: 12). Therefore, the European Commission has organisational interests in seeking strict and nondiscriminatory regulations to maintain such credibility. Regarding the role of ideas, a linkage between competition and internal market policies is the key to the better understanding of the EU's stringent competition policy. As explained in Chapter 2 of this book, EU competition policy seeks to promote regional economic integration by combatting anticompetitive business practices that affect trade between EU member states. This 'unification imperative' (Gerber 1994: 98) is evident in various official documents of the European Commission as well as case law (European Commission 2011: 4-5; Goyder and Albors-Llorens 2009: 11-12; Jones and Sufrin 2016: 35-36). This implies that the European Commission perceives competition regulations through the lens of a single market project. In other words, the Commission seeks to ensure that anticompetitive business practices do not substitute traditional trade barriers among EU member states. Thus, it makes sense that the Commission prioritises the promotion of competition rather than the enhancement of international competitiveness of EU firms in the enforcement of EU competition law.

The second question is whether the EU's stringent competition policy constitutes de facto barriers to trade with non-EU countries. A distinction between 'positive integration' and 'negative integration' in EU studies is useful to address this question. Positive integration refers to the creation of new common rules, such as environmental law and consumer law. In the case of positive integration, stringent regulations could constitute trade barriers because foreign firms must bear the cost of compliance with such regulations. In this sense, the EU's 'non-discriminatory' measures could negatively affect non-EU firms in practice. Conversely, negative integration, which refers to the elimination of trade barriers and distortions of competition, is unlikely to obstruct import and foreign direct investment. On the contrary, negative integration generally encourages such transactions by ensuring a level-playing field. As the establishment of supranational competition rules is a typical example of negative integration, the EU's stringent competition policy would not constitute barriers to trade. A potential source of barriers to entry is not the strict enforcement of competition law, but the lax enforcement of such law. This is evident in the complaints of the United States in the Japan-Film case and the Mexico-Telecoms case in the WTO analysed in Chapter 5.

\subsection{Venues for future research}

Building on the findings of this book, future research may focus on the following three topics. The first is the EU's role as a global rule-maker in the area of competition. More research on the effectiveness of the EU's rule transfer through bilateral and interregional agreements needs to be conducted to further our 
understanding of the EU's external competition relations. The literature on the EU's global regulatory influence (Young 2016) and the conceptual framework of Market Power Europe (Damro 2012) would be useful for further research on this topic. It would also be interesting to analyse the long-term impact of the EU's competition regulation on non-EU firms and business associations. There are already pieces of evidence that indicate such an impact. For example, in 2018, the JBCE that represents the interests of Japanese firms in Europe published a four-page-long document entitled 'JBCE Competition Law Compliance Guidelines'. This document states that it is 'the policy of Japan Business Council in Europe (JBCE) to comply strictly with all applicable EU and national competition rules', and any activities of JBCE or JBCE-related actions of its members that violate competition law are 'detrimental to the interests of the association and damage all of its members'. Therefore, such activities are 'contrary to JBCE policy' (JBCE 2018: 1). These statements indicate a degree of internalisation of EU norms by this business association. In fact, the JBCE encourages its members to establish competition law compliance programmes. Empirical research on this topic would enhance our understanding of the EU's global regulatory influence.

The second topic is ongoing debates over a reform of EU competition rules. In the mission letter of 1 December 2019, the President of the European Commission, Ursula von der Leyen, mandated Margrethe Vestager to 'evaluate and review' EU competition rules in her second term as the Competition Commissioner. Furthermore, von der Leyen mandated her to 'develop tools and policies to better tackle the distortive effects of foreign state ownership and subsidies in the internal market' as part of the EU's industrial strategy (von der Leyen 2019: 5-6). In October 2020, the European Commission published a work programme for 2021 and stated that it will 'continue its ongoing review of competition rules' and 'propose a legal instrument to level the playing field as regards foreign subsidies' in 2021 to ensure a fair business environment (European Commission 2020: 4). These official statements clearly show the European Commission's intention to amend its competition rules in two areas: state aid control regarding foreign subsidies and merger control regarding the acquisition of major EU firms by non-EU state-owned enterprises. This indicates that the EU would strengthen the connection between its competition, trade, and industrial policies to address the challenge of increasing economic competition and trade friction with the United States and China. It remains to be seen how exactly the EU will reform its competition policy.

The final research topic that deserves serious consideration is the impact of the ongoing outbreak of COVID-19 on EU competition policy, especially in the field of state aid control. This case provides a good test of how resilient (or vulnerable) EU competition policy is to changes in macroeconomic conditions and prevailing politics. Since early 2020, the pandemic has severely impacted the EU economy and prompted EU member states to grant massive state aid to their industries. In 2020, the European Commission approved 66 notified state aid measures under Articles 107(2)(b), 107(3)(b), and 107(3)(c) of the 
TFEU (European Commission 2021). Furthermore, the European Commission adopted a temporary framework ${ }^{3}$ on 19 March 2020 based on Article 107(3) (b) (i.e. the key provision on emergency state aid) to enable EU member states to support their economies in a more flexible way. After consulting with EU member states and other stakeholders, the European Commission has amended the temporary framework five times by the time of writing (March 2021) in order to prolong it and extend its scope. A total of 343 notified state aid measures from all member states were approved in 2020 based on this framework (European Commission 2021). ${ }^{4}$ Thus, in the initial phase of this economic crisis, the European Commission clearly relaxed its state aid rules, as it did during the global financial crisis of 2007-2008. A key question is whether this 'temporary' relaxation of state aid control would eventually lead to a fundamental change to EU competition policy in terms of decision-making processes and substantive rules. Regarding this issue, Meunier and Mickus (2020: 1082) predict that, 'post-pandemic, the EU will more aggressively protect and promote European competitiveness, in line with pre-pandemic arguments in favor of a EU-wide industrial policy'. If their prediction is accurate, that would mean a shift in EU competition policy from a stringent approach to a strategic one. Future research should explore this proposition, which is of paramount importance for the future of EU competition policy.

\section{Notes}

1 See Buigues, Jacquemin, and Sapir (1995) for discussions on this subject in the context of EU studies.

2 The author is grateful to Tetsukazu Okamoto and Shoichiro Ishibashi for their comments on this point.

3 Communication from the Commission: Temporary Framework for State aid measures to support the economy in the current COVID-19 outbreak, OJ C91 I/1, 20 March 2020.

4 This figure includes five state aid schemes notified by the United Kingdom after its withdrawal from the EU on 31 January 2020.

\section{References}

Buigues, P., Jacquemin, A. and Sapir, A. (eds) (1995). European Policies on Competition, Trade and Industry: Conflict and Complementarities. Aldershot: Edward Elgar.

Damro, C. (2012). Market Power Europe. Journal of European Public Policy, 19(5), pp. 682-699.

European Commission (2010). Europe 2020: A Strategy for Smart, Sustainable and Inclusive Growth, $\operatorname{COM}(2010) 2020$ final.

European Commission (2011). Report on Competition Policy 2010, COM(2011)328 final.

European Commission (2020). Commission Work Programme 2021: A Union of Vitality in a World of Fragility, COM(2020)690 final.

European Commission (2021). Coronavirus Outbreak: List of Member State Measures Approved Under Articles 107(2)b, 107(3)b and 107(3)c TFEU and Under the State 
Aid Temporary Framework (last update: 25 March 2021) [Online]. Available at: https://ec.europa.eu/competition/state_aid/what_is_new/State_aid_decisions_TF_ and_107_2b_107_3b_107_3c.pdf [accessed: 31 March 2021].

Gerber, D. J. (1994). The Transformation of European Community Competition Law. Harvard International Law Journal, 35(1), pp. 87-95.

Goyder, J. and Albors-Llorens, A. (2009). Goyder's EU Competition Law, 5th ed. New York: Oxford University Press.

JBCE (2018). JBCE Competition Law Compliance Guidelines [Online]. Available at: https://www.jbce.org/wp-content/uploads/2018/01/JBCE-Competition-LawCompliance-Guidelines.pdf?x59080 [accessed: 31 March 2021].

Jones, A. and Sufrin, B. (2016). EU Competition Law: Text, Cases, and Materials, 6th ed. Oxford: Oxford University Press.

Majone, G. (1999). The Regulatory State and Its Legitimacy Problems. West European Politics, 22(1), pp. 1-24.

Meunier, S. and Mickus, J. (2020). Sizing up the Competition: Explaining Reform of European Union Competition Policy in the Covid-19 Era. Journal of European Integration, 42(8), pp. 1077-1094.

von der Leyen, U. (2019). Mission Letter: Margrethe Vestager: Executive Vice-President for a Europe Fit for the Digital Age [Online]. Available at: https://ec.europa.eu/ commission/commissioners/sites/comm-cwt2019/files/commissioner_mission_ letters/mission-letter-margrethe-vestager_2019_en.pdf [accessed: 31 March 2021].

Young, A. R. (ed) (2016). The European Union as a Global Regulator? Abingdon: Routledge. 


\section{INDEX}

Italicized and bold page numbers refer to figures and tables. Page numbers followed by " $n$ " refer to notes.

Abbott, K. W. 133n10

Abbott, R. 132n2

abuse of dominance $2,5,7,15,22,25$, 30-32, 37, 41, 76, 84-92, 85, 99, 101, 131, 138, 139; fines for $84-85,85$

Adobe 88

Advisory Committee 25, 27

Agfa 122

Almunia, J. 5, 69, 79-80, 89

Altmaier, P. 57

Amazon 69, 91

American Bar Association: Section of Antitrust Law 129

Apple 5, 69, 70, 89, 92

Asahi Glass 81

Axel Springer 90

Aydin, U. 109

Bali Ministerial Conference (2013) 120-121

BASF 79

Belgium: tax exemption scheme 69

Bertelsmann 100

BEUC see European Consumer Organisation (BEUC)

bilateral cooperation 130-132

Blauberger, M. 16n1, 109

Boeing 108

Botta, M. 12-13, 17n10
Bradford, A. 94

Brazil 129, 131

Brittan, L. 24

Buch-Hansen, H. 7

Buigues, P. 144n1

Bush, G.W. 96

Canada 130

Cancun Ministerial Conference, Mexico (2003) 117, 119, 120

Caporaso, J. M. 17n8

cartels 76-83, 101; complaints from

Japanese business community $81-83$; discrimination issue, fines for $77-81$, 78-79; discrimination issue, frequency of 77-81, 78-79

'Checklist of Issues Suggested for Study, A,' 116

China 131; competition policy 5

Ciao 91

CNE see Comisión Nacional de Energía (CNE)

Cold War 110

collective dominance 31

College of Commissioners 10, 25, 52, 96

Comisión Nacional de Energía (CNE) 63 commitment decisions 28,31

competition-competitiveness dilemma 1 , 2, 15, 16n1, 21, 43, 48, 107, 109, 113, $132,137-140$

Consten-Grundig case 28-29

Constitutional Treaty of 20044

Corel 88 
Cotonou Agreement 130

Cremieux, P. 78

Dabbah, M. M. 124

DAF 80

Daimler 80

Damro, C. 7

DG Competition 13, 14, 17n11, 25, 30, 102, 120, 127, 129, 131; abuse of dominance 84 ; administrative burden 26 ; investigative powers 28 ; merger control 32, 93; state aid control 35; Volvo/Scania case 52

DGs see Directorate-Generals (DGs)

Directive 2003/54/EC 60

Directive 2003/55/EC 60

Directive 2009/72/EC 60

Directive 2009/73/EC 60

Directive 2014/104/EU on Antitrust Damages Actions 25, 43n2

Directive (EU) 2019/1, 27, 43n4

Directorate-Generals (DGs) 10

discrimination against non-EU firms, issue of 7, 76-103; abuse of dominance 84-92; cartels 76-83; mergers 92-100

Doha Ministerial Conference (2001) 116-118

eBay 91

EC see European Communities (EC)

ECIS see European Committee for Interoperable Systems (ECIS)

ECN see European Competition Network (ECN)

Ecofin Council 67

ECSC see European Coal and Steel Community (ECSC)

EC Treaty: Article 82 84, 86, 87, 99; Article 82(2) 69; Article 87(3)(b) 67, 68; Article 87(3)(c) 67; Articles 87-89, 66

EEC see European Economic Community (EEC)

Ehlermann, C.-D. 132n2

eJustice 91

ENGIE 69

E.ON/Endesa case 60-66

EU see European Union (EU)

EU Council 25, 26

EU-Japan agreement (2003): 130; Article 2 82; Article 2(1) 82; Article 2(2) 82

EURACTIV 5, 57

Europe 2020 4, 140

European Coal and Steel Community (ECSC) 4, 22
European Commission 22, 23, 101, 102, 108, 114, 139-144; abuse of dominance 31-32; on competition policy $1-6$, 8-10; 'Completing the Internal Market' white paper (1985) 24; DG for Trade ('DG Trade') 120; extraterritorial jurisdiction and external relations, legal and political basis for 39-43; Global Europe: Competing in the World ('the Global Europe trade strategy') (2006) 109; merger control 32-35, 49, 50, 92-100; policy instruments 14 ; political conflict with member states 14-15; position in EU competition law enforcement 27; prohibition decisions 13; Siemens/Alstom case 55-60; state aid control 35-37, 37, 66-71, 70; Volvo/Scania case $51-54$

European Committee for Interoperable Systems (ECIS) 88

European Communities (EC) 23

European Competition Commissioners 24

European Competition Network (ECN) 26-27; 'ECN plus' directive 27

European competition regulation, political debates about 3-6

European Consumer Organisation (BEUC) 92

European Economic Area 110

European Economic Area Agreement 130

European Economic Community (EEC) 4; Council of Ministers 22, 24, 25, 36,42

European Parliament 25

European single market 1, 8, 16n3, 23, 24, 29, 38, 53

European Union (EU): budget 9; capacity 12; cartel policies 7, 29; competition policy dilemma 1-17 (see also individual entries); exclusive competence in large cross-border mergers 64; external competition relations, evolving strategy for 125-132; external engagement, political and economic reasons for 108-110; external relations 8; failed attempt to establish WTO competition law 110-125; role as global rule-maker, systemic constraints on 107-133; stuck between competition and competitiveness 137-144; unity 12

EU-Switzerland agreement (2014): 130; Articles 7-10, 133n17 exclusivity principle 64 Expedia 92 
external relations, legal and political basis for 38-43

extraterritoriality 6, 38, 39, 40, 42, 95

extraterritorial jurisdiction, legal and political basis for 38-43

Falkner, G. 11

F. Hoffmann-La Roche: cartel control 78,79

Fiat 69, 70

First World War 22

Foreign Trade Antitrust Improvements Act of 198238

Foundem 91

Fox, E. M. 133 n 8

France 23, 25-26, 55-59, 90; European Commission's state aid decisions 69-70 free trade agreements (FTAs) 43, 130-132, 133n19, 139

FTAs see free trade agreements (FTAs)

Fuji Electric: cartel control 82

GATS see General Agreement on Trade in Services (GATS)

GATT see General Agreement on Tariffs and Trade (GATT)

GE Capital Aviation Services (GECAS) 96, 97

GECAS see GE Capital Aviation Services (GECAS)

GE/Honeywell case 95-100

General Agreement on Tariffs and Trade (GATT) 111, 118, 121; Article 3(4) 123; Article 10(1) 123; Kennedy Round (1964-1967) 122; Tokyo Round (1973-1979) 122; Uruguay Round (1986-1994) 122

General Agreement on Trade in Services (GATS) 113, 121; Annex on Telecommunications 124-125

Gerber, D. J. 103n28

Germany 55-59, 90

Giotakos, D. 103n29

global financial crisis of 2007-2008 2, $4,15,36,139$; state aid control and 66-71, 70

Google 5, 15, 89, 101; abuse of dominance 32, 84; Google Android 85; Google Search (AdSense) 85; Google Shopping 5, 85, 89-92; mobile software 89-92; online advertising 89-92

Great Depression 22, 111

Greven, G. 53
Group of Twenty 69

Guay, T. R. 7

Harker, M. 65

Havana Charter 111, 114; Article 46 111; Article 50111

Hitachi: cartel control 82

Hollings, E. 99

IBM 88

Iceland 110

ICN see International Competition Network (ICN)

ICPAC see International Competition Policy Advisory Committee (ICPAC) implementation doctrine 39

India 131

industrial policy $3,4,58-59$

integrationist policy 49

Intel: abuse of dominance 84

International Bar Association 127

International Competition Network (ICN) 2, 13, 16, 43, 82, 107, 131, 139; distinguished from WTO 129; implications of 126-130; rise of 126-130; Steering Group 127, 128, 133n11; Vision for its Second Decade 129

International Competition Policy Advisory Committee (ICPAC) 126

international competition rules, patchwork of 111-112

international competitiveness, politics of $55-60$

International Monetary Fund 111

International Trade Organization (ITO) 111 ; 'one country, one vote' principle 111

interregional cooperation 130-132

Italianer, A. 4

ITO see International Trade Organization (ITO)

Iveco 80

Jackson, R. J., Jr. 94

Jacquemin, A. 132n2, 144n1

James, C. 97

Japan 102, 116, 119, 130, 131; cartel complaints from business community 81-83; Japan Business Council in Europe (JBCE) 13, 15, 83, 103n11, 140, 143; Japanese Antimonopoly Law 123; Japan External Trade Organization (JETRO) 81; Japan Fair Trade Commission (JFTC) 81-83, 122; 
'JBCE Competition Law Compliance Guidelines,' 143; Large Stores Law of 1973 122, 123; Ministry of Economy, Trade and Industry (METI) 13, 77, $78,83,122,123$; perspective on EU competition policy 13; Premiums Law 122, 123

Japan AE Power Systems 82

Japan-Film case 121-125

Jenny, F. 116, 132n2

JETRO see Japan External Trade

Organization (JETRO)

Johansson, L. 51

Jones, A. 26

Juncker, J.-C. 5, 57

Kaeser, J. 55

Kauffmann, C. 133 n10

Klein, J. 119, 126, 127

Kodak 122

Korean War 111

Krämer, R. U. 16n1, 109

Kroes, N. 4, 30, 61, 64, 68, 82, 83, 88, 100

Kudrna, Z. 11

Lagardère 90

Lamoureux, F. 132n2

Lee, J. R. 133n10

Le Maire, B. 56, 58

Leucht, B. 43n1

LG Electronics: cartel control 78

Liechtenstein 110

Like-Minded Group 118

Lisbon Strategy 4

Lisbon Treaty of 20074

Lotus 89

Lowe, L. 92

Luxembourg: European Commission's state aid decisions 69, 70

Majone, G. 8

MAN 80

Marchipont, J.-F. 132n2

market: competition 139; definitions, politics of 51-54; dominance 31 ; liberalisation 24, 60; share 49-50

Market Power Europe 38, 143

'market-sharing' agreements 28

McDonald's 69

McDonnell Douglas 108

McGowan, L. 17n4

'merger-constraining' policy 49

merger control 3, 14-15, 24-25, 32-35, 40, 48-66, 92-100, 127, 143 mergers 92-100; disapproved by European Commission 1990-2020 93; GE/Honeywell case 95-97; transatlantic divide, causes and implications of 98-100

Meunier, S. 144

Mexico 129, 131

Mexico-Telecoms case 121-125

Mickus, J. 144

Microsoft 15, 91, 92, 101; abuse of dominance 31-32, 84, 85; interoperability 86-89; Tying 88-89

Mitsubishi Electric 82; cartel control 81 'modernisation reforms' of 200426 Monopoly Commission of Germany 61 Montebourg, A. 4-5

Monti, M. 33, 52-54, 79, 86, 96, 97, 100, 127

Mozilla 89

MTPD 83

Müller, P. 11

multilateralism 113

national neo-mercantilism and stringent supranational regulations, tension between 48-72; E.ON/Endesa case 60-66; Siemens/Alstom case 55-60; state aid control, economic crisis and 66-71, 70; Volvo/Scania case 51-54

neoliberalism 24

neo-mercantilist style of competition policy 7

Netherlands, the: European Commission's state aid decisions 69, 70

Nihon Keizai Shimbun 81

Nokia 88

Norway 110

Novell 89

NTN: cartel control 81

OECD see Organisation for Economic Cooperation and Development (OECD)

Oettinger, G. 90

oil crises of the 1970s 23

Okonjo-Iweala, N. 121

O’Neill, P. 97

'one-stop shop' principle 33

Opera 88, 89

Organisation for Economic Cooperation and Development (OECD) 13, 43, 69, 77, 110, 113, 115, 119, 122, 128, 131, 133n18, 133n19; Competition Committee 112 
Palacio, L. de 96

Panasonic: cartel control 81, 83

Persson, G. 52

Philips 80

1plusV 91

policy export 11-12; definition of 11

Pons, J.-F. 114, 119, 132n2

Poupart-Lafarge, H. 55

'price-fixing' agreements 27-28

prohibition decisions 31

Protocol No. 27, 4

Qualcomm: abuse of dominance 84 qualified effects doctrine 39

RealNetworks 88, 89

Red Hat 88

Regulation 1/2003 43n3; abuse of dominance 31; Article 2 26; Article 5 26; Article 7 28, 31, 43n5; Article 9 28, 31, 90; Article 11(6) 26; Article 23 43n5; Article 23(2) 28; Articles 17-21, 28; restrictive practices 28

Regulation 17/62, 23, 25

Regulation 139/2004 44n18, 95; Article 1 34, 40, 62, 64; Article 1(2) 34; Article 1(3) 34; Article 4 33; Article 633 ; Article 7 33; Article 8 33; Article 8(2) 92; Article 8(3) 92; Article 9 44n19, 64; Article 10 34; Article 14 34; Article 21 64; Article 22 44n19; merger control 33-34

Regulation 651/2014 35

Regulation 2015/1589 36, 44n22

Regulation 4064/89, 25

Regulation 659/1999 44n24

Reno, J. 126

Republic of Korea (South Korea) 116, 119, 130

Rescue and Restructuring Guidelines (2004) 68

restrictive practices $3,22,24-31,37,90$, 91, 122, 138

Rosengren, B. 53

Roth, W. H. 10, 11

Royal Decree-Law 4/2006 63

Russia 131

Saint Gobain: cartel control 82

Sapir, A. 144n1

Sarkozy, N. 4, 69

Seattle Ministerial Conference (1999) 116, 117

Second World War 21
Sengupta, P. 117

Sherman Antitrust Act 38

Siemens/Alstom case 55-60

Singapore issues 120; Committee on Trade in Goods 132-133n3; Singapore Ministerial Conference (1996) 116; Singapore Ministerial Declaration (1996) 115, 117; Working Group on Trade and Investment 132n3; Working Group on Transparency in Public Procurement 132n3

single economic entity doctrine 39

Single European Act 23, 25

Slaughter, A. M. 133n10

Smith, B. 87

Snyder, E. A. 78

Sony 100

South Africa 129, 131

Stabilisation and Association Agreements 130

Starbucks 69

state aid control 3, 4, 14-16, 35-37, 37, 107, 129, 138, 139, 143, 144; economic crisis and 66-71, 70

strategic competition policy 7, 49, 102; compared with stringent competition policy 11; definition of 10-11; merger control 50

strict and non-discriminatory regulation, institutional basis of 21-45; abuse of dominance 30-32; external relations, legal and political basis for 38-43; extraterritorial jurisdiction, legal and political basis for 38-43; merger control 32-35; restrictive practices 27-30; state aid control 35-37, 37; supranational governance 21-27 stringent competition policy 2, 7, 49, 141-142; compared with strategic competition policy 11; definition of 10 ; merger control 50

stringent supranational regulations and national neo-mercantilism, tension between 48-72; E.ON/Endesa case 60-66; Siemens/Alstom case 55-60; state aid control, economic crisis and 66-71, 70; Volvo/Scania case 51-54

Sufrin, B. 26

Sun Microsystems ('Sun') 87-89

supranational governance 21-27

Sutherland, P. 24

Switzerland 130

Szczepański, M. 16n2 
Takeda Chemical Industries 79

Technicolor 80

TFEU see Treaty on the Functioning of the European Union (TFEU)

Thatcher, M. 49

Time Warner 89

Toshiba: cartel control 81-83

transatlantic divide, causes and implications of $98-100$

Treaty of Paris of 1951 4, 22

Treaty of Rome of 1957: Article 3(f) 4; Article 82 31; Article 85 22-24; Article 85(3) 23; Article 86 22-24; Articles 85-94, 22

Treaty on the Functioning of the European Union (TFEU) 143-144; Article 3(1) 25; Article 101 22, 26-28; Article 101(1) 27; Article 101(3) 26, 28; Article 102 22, 26, 27, 30-32, 41, 84, 86, 89, 91, 99; Article 107(1) 35, 66; Article 107(2) 35; Article 107(2)(b) 143; Article 107(3) 35; Article 107(3)(b) 35, 66, 143; Article 107(3)(c) 143; Article 108(2) 26, 44n22; Article 108(3) 36, 66; Article 114 25; Articles 107-109, 35,66

Trump, D. 5

Trump administration 121

UN see United Nations (UN)

UNCTAD see United Nations Conference on Trade and Development (UNCTAD)

United Kingdom: European Commission's state aid decisions 69

United Nations (UN) 110; International Trade Organization 111

United Nations Conference on Trade and Development (UNCTAD) 13, 43, 110, 113, 128, 131; Intergovernmental Group of Experts on Competition Law and Policy 112; Set of Mutually Agreed Equitable Principles and Rules for Control of Restrictive Business Practices ('the Set') 112

United States (US) 15, 102, 107, 130, 139, 140; cartel control 78; cartel policies 7; competition policy 2,5 ; critiques of EU's proposal for the WTO competition law 119; Department of Justice 126; dismissal of Havana Charter 111; extraterritorial application of competition law 38-39; merger control 35, 94-98

US see United States (US)

Van Miert, K. 114, 132n1

Van Miert Report 114

Verband freier Telefonbuchverleger 91

Vestager, M. 5-6, 57, 69, 77, 90, 100-101

Volvo/Renault case 54

Volvo/Scania case 51-54

von der Leyen, U. 5, 143

von der Leyen Commission 35

Weimer Republic: competition law 22

Welch, J. 95

Western Europe 21; privatisation and market liberalisation trend in 8

Wigger, A. 7

World Bank 111

World Trade Organization (WTO) 2, 6, 16, 107, 139; competition law, EU's failed attempt to establish 110-125; disputes over trade and competition 121-125; international competition rules, patchwork of 111-112; negotiation deadlock regarding competition rulemaking 113-121; decision-making procedures and trade disputes 12; Dispute Settlement Body 123, 124; distinguished from ICN 129; Doha Round (or Doha Development Agenda) 113, 117, 120, 121; General Council 116, 117; Ministerial Conference 115; 'Singapore issues, the,' 113; subsidy control 36; Working Group on the Interaction between Trade and Competition Policy 115

WTO see World Trade Organization (WTO)

Yahoo 91

Yazaki: cartel control 81

Yelp 92

YKK: cartel control 81

Yomiuri Shimbun 81

Zytnick, J. 94 


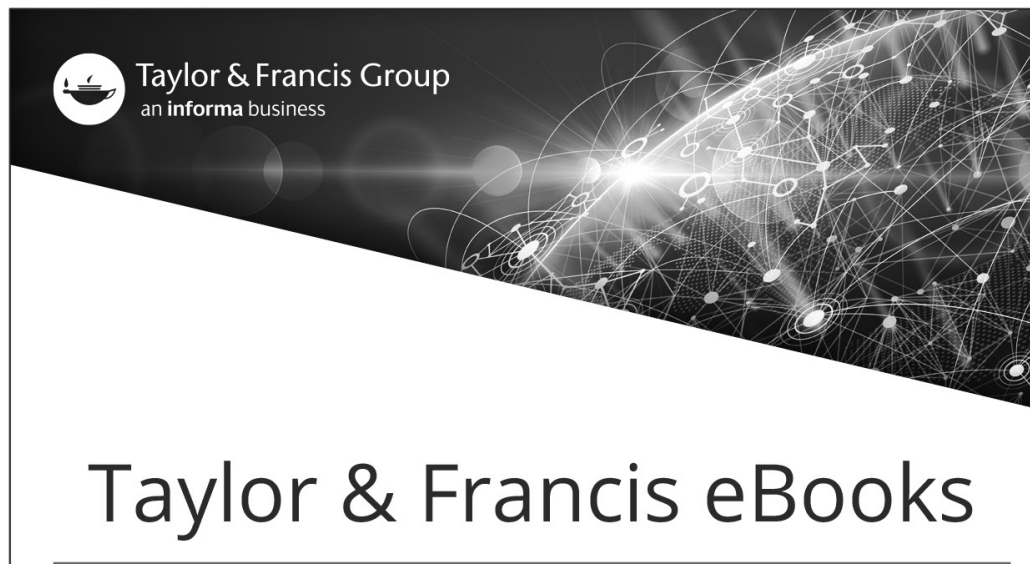

www.taylorfrancis.com

A single destination for eBooks from Taylor \& Francis with increased functionality and an improved user experience to meet the needs of our customers.

90,000+ eBooks of award-winning academic content in Humanities, Social Science, Science, Technology, Engineering, and Medical written by a global network of editors and authors.

TAYLOR \& FRANCIS EBOOKS OFFERS:
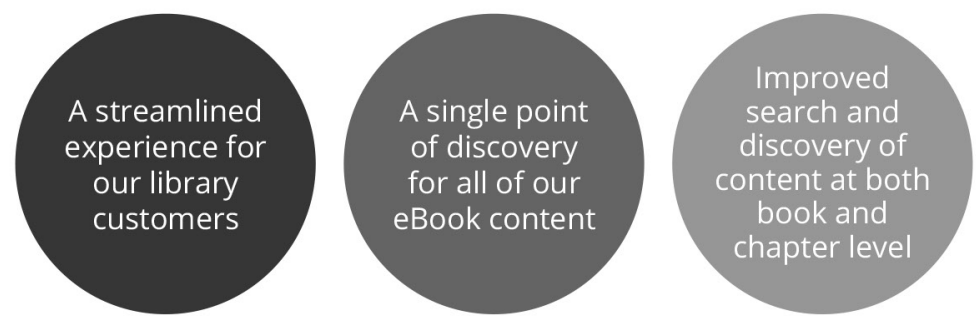

\section{REQUEST A FREE TRIAL support@taylorfrancis.com}

\section{Routledge \\ Taylor \& Francis Group \\ CRC Press \\ Taylor \& Francis Group}

